\title{
EXPENDITURE SWITCHING AND EXCHANGE RATE POLICY
}

\author{
Charles Engel \\ Working Paper 9016 \\ http://www.nber.org/papers/w9016 \\ NATIONAL BUREAU OF ECONOMIC RESEARCH \\ 1050 Massachusetts Avenue \\ Cambridge, MA 02138 \\ June 2002
}

This paper was prepared for the NBER Macro Annual 2002. The National Science Foundation has supported this research through a grant to the University of Wisconsin-Madison. I thank the discussants, Karen Lewis and Pierre Olivier Gourinchas, as well as Mick Devereux and Ken West for helpful comments, and Akito Matsumoto and Shiu-Sheng Chen for excellent research assistance. The views expressed herein are those of the author and not necessarily those of the National Bureau of Economic Research.

(C) 2002 by Charles Engel. All rights reserved. Short sections of text, not to exceed two paragraphs, may be quoted without explicit permission provided that full credit, including $(\mathcal{C}$ notice, is given to the source. 
Expenditure Switching and Exchange Rate Policy

Charles Engel

NBER Working Paper No. 9016

June 2002

JEL No. F3, F4

\begin{abstract}
Nominal exchange rate changes can lead to "expenditure switching" when they change relative international prices. A traditional argument for flexible nominal exchange rates posits that when prices are sticky in producers' currencies, nominal exchange rate movements can change relative prices between home and foreign goods. But if prices are fixed ex ante in consumers' currencies, nominal exchange rate flexibility cannot achieve any relative price adjustment. In that case nominal exchange rate fluctuations have the undesirable feature that they lead to deviations from the law of one price. The case for floating exchange rates is weakened if prices are sticky in this way. The empirical literature appears to support the notion that prices are sticky in consumers' currencies. Here, additional support for this conclusion is provided. We then review some new approaches in the theoretical literature that imply an important expenditure-switching role even when consumer prices are sticky in consumers' currencies. Further empirical research is needed to resolve the quantitative importance of the expenditure-switching role for nominal exchange rates.
\end{abstract}

\author{
Charles Engel \\ Department of Economics \\ University of Wisconsin \\ 1180 Observatory Drive \\ Madison, WI 53706-1393 \\ and NBER \\ cengel@ssc.wisc.edu
}




\section{Introduction}

Exchange-rate flexibility, it has been argued, is useful because it facilitates relative price adjustment among countries. Currency depreciation is a quick and painless way to lower domestic prices relative to foreign prices. Much attention has been paid recently to the benefits of exchange-rate stability in emerging economies. That literature has focused on the potential for greater monetary and financial stability from either fixing exchange rates, or taking more extreme measures such as adopting a currency board or dollarizing. But that analysis is not directly applicable to the choices facing many advanced countries - such as the decision to adopt the euro for some European countries. These countries uniformly have stable monetary policy (at least as stable as the policy conducted by the European Central Bank) and have deep, well-regulated financial markets. The economic benefit of adopting the euro lies in the increased efficiency of transactions and the elimination of uninsurable exchange-rate risk. On the other hand, a country adopting the euro cedes its monetary policy to the European Central Bank, and no longer has the option of using monetary policy to respond to local conditions. Furthermore, adopting the euro eliminates one possible avenue for adjustment between countries - the relative price changes induced by exchange rate movements. It is this latter effect that is the focus of this study.

Recent evidence has found that consumer prices in rich countries are not much affected by nominal exchange rate changes in the short run. This finding may imply that nominal exchange rate changes do not play much of a role in changing relative prices of goods. If consumer prices are not responsive to exchange rates, then a depreciation of the home currency, for example, does not increase much the price that consumers pay for imported goods. However, there are other interpretations of the evidence on exchange rates and consumer prices. For example, there might be important relative price effects but not for final consumer goods. One possibility is that intermediate firms substitute between

\footnotetext{
${ }^{1}$ I have been the perpetrator of some of this literature: for example Engel $(1993,1999)$ and Engel and Rogers (1996, 2001). Other works include Rogers and Jenkins (1995), Obstfeld and Taylor (1997), Parsley and Wei (2001a, 2001b), and Crucini, Telmer, and Zachariadis (2001). Mussa's (1986) classic paper stimulated much of this research.
} 
domestic and foreign goods based on relative price changes, but set prices for consumers in a way that is unresponsive to exchange-rate changes.

The extent to which exchange rates alter relative prices may be important for determining the desirability of exchange-rate flexibility among advanced nations. Milton Friedman (1953), an early advocate of flexible exchange rates, argued that one advantage of floating rates is that they could allow rapid change in relative prices between countries (p. 162):

"A rise in the exchange rate ... makes foreign goods cheaper in terms of domestic currency, even though their prices are unchanged in terms of their own currency, and domestic goods more expensive in terms of foreign currency, even though their prices are unchanged in terms of domestic currency. This tends to increase imports [and] reduce exports."

This passage makes two assumptions: that goods prices are unchanged in the currency of the producer of the good, and that there is significant pass-through of the exchange rate change to the buyer of the good. On the nominal price stickiness, Friedman argues that the choice of exchange-rate regime would matter little if nominal goods prices adjusted quickly to shocks (p. 165):

"If internal prices were as flexible as exchange rates, it would make little economic difference whether adjustments were brought about by changes in exchange rates or by equivalent changes in internal prices. But this condition is clearly not fulfilled. ... At least in the modern world, internal prices are highly inflexible."

In assessing this relative-price effect and its significance for the choice of exchange-rate regime, Friedman is certainly correct to emphasize the importance of nominal goods price stickiness. As Buiter (1999) has forcefully emphasized, the decision to join a monetary union, or the choice of an exchangerate regime, is a monetary issue. Relative-price behavior is usually independent of monetary regime in a world of perfect goods price flexibility. The choice of monetary regime in this case only matters for short-run adjustment problems - the period during which nominal prices are adjusting.

The pioneering work of Obstfeld and Rogoff (1995, 1998, 2000a) has assumed that nominal prices are fixed in the producers' currencies, so that prices for consumers change one-for-one in the short run with changes in the nominal exchange rate. This is exactly the assumption of Friedman. I shall call this the PCP (for "producer-currency pricing") model. The Obsteld-Rogoff (hereinafter, OR) models offer a sound analytical foundation for the claim that flexibility of exchange rates is desirable in this 
setting 2 They derive three important results: (1) Exchange-rate flexibility achieves relative price adjustment under PCP pricing. Indeed, in their models, flexible exchange rates are a perfect substitute for flexible nominal prices. That is, the flexible nominal price allocations are achieved with PCP pricing but flexible exchange rates. (2) The policy that achieves the flexible price allocation is a constrained Pareto optimum. The monetary authorities can do no better. (3) This optimal policy is completely self-oriented. No policy coordination across countries is required or desirable. In this sense, perfectly flexible exchange rates are optimal.

The key role of nominal exchange rate flexibility in these models is that it allows for expenditure switching. That is, in the presence of real shocks that are specific to one country (such as productivity shocks, labor supply shocks, government spending shocks, etc.), nominal exchange rate changes allow adjustment of relative prices of goods across countries. These changes in relative prices can replicate the changes in relative prices that occur in flexible price economies. For example, a country that experiences a productivity increase should experience a decline in the price of its output that induces a switch in expenditures toward the domestic product. In the PCP framework, even though nominal prices are sticky in the producers' currencies, this relative price decline can be accomplished by nominal currency depreciation.

A number of recent papers (Betts and Devereux (1996, 2000), Chari, Kehoe, and McGrattan (2000), and others) have examined OR-style models in which nominal prices are set in advance in the currency of consumers. In that case, nominal exchange rate changes do not, in the short run, change any prices - nominal or real - faced by consumers. I shall call this the LCP (for "local-currency pricing") model. Devereux and Engel (2001) have examined monetary policy in this setting, and have concluded that there is no case for nominal exchange rate flexibility - indeed, fixed exchange rates are preferred.

The size of the expenditure switching effect is important in international macroeconomics not only for how it might influence optimal monetary policy. The literature dating back to Mundell (1968)

\footnotetext{
${ }^{2}$ See Lane (2001) for an excellent general survey of the work stimulated by Obstfeld and Rogoff.
} 
and earlier ${ }^{3}$ has emphasized the expenditure-switching role of nominal exchange rate changes in transmitting business cycle fluctuations between countries. On the other hand, Krugman (1989) has argued that nominal exchange rate volatility might be accentuated if the expenditure-switching effect is small. The smaller the effect of exchange rate changes on relative prices, and hence on relative demands, the larger the exchange-rate change is required to reach equilibrium.

Sections 2, 3, 4, and 5 of the paper lay out the framework of the new open-economy macroeconomics. I discuss why floating exchange rates are desirable under PCP, but fixed exchange rates may be optimal under LCP. Empirical evidence supports the notion that consumer prices are not very responsive in the short run to nominal exchange rate changes. Section 6 reviews some of that empirical evidence, and adds some new supporting evidence.

But the apparent small response of consumer prices to exchange rate changes in the short run does not necessarily imply that nominal prices are sticky in consumers' currencies, or that the expenditure-switching effect is small. In OR (2000b), transportation costs and distribution costs increase the cost of imported goods, and serve to segment national markets. Even if imported goods are nearly perfect substitutes for domestically produced goods, they may not be consumed in great quantity because their cost is higher. In that case, an exchange rate change will have only a small effect on the consumer price index.

A related approach observes that the actual physical good is only a small part of what the consumer buys. The consumer also pays for the nontraded marketing, distribution and retailing services that bring the good to the buyer. Perhaps these costs are quite large, and dominate the cost of the physical good. If so, the influence of exchange-rate changes on real allocations is likely to be small, since the exchange rate change only affects a small part of the cost of the good cum service purchased by the consumer. This is the approach taken by McCallum and Nelson (2000).

\footnotetext{
${ }^{3}$ See Obstfeld (2001) for a survey of pre-Mundellian literature.

${ }^{4}$ Devereux and Engel (2002) explore this argument and its limitations in the context of new open-economy macro models.
} 
In both of these models, nominal consumer prices of imported goods are not sticky. But some new evidence will be presented in sections 7 and 8 that suggests these models are, at best, only a small part of the explanation for the lack of responsiveness of consumer prices to exchange rate changes. It seems likely that there is a significant degree of nominal consumer price stickiness. However, sticky consumer prices in themselves do not necessarily rule out an important expenditure switching effect.

Obstfeld (2001) and Devereux, Engel, and Tille (1999) model imported goods as intermediates in the production of final consumer goods. In Obstfeld, there are domestic substitutes for the import, while in Devereux, Engel, and Tille there are not. When there are substitutes, the importer might switch between the imported intermediate and the locally produced alternative when the exchange rate changes. Obstfeld argues that in this type of economy, there may indeed be a significant expenditure-switching effect. It is not consumers who switch between imports and locally produced goods, but rather local producers who combine intermediate goods to make the final consumer product. It is both the degree of pass-through and the amount of substitutability that determine the strength of the expenditure-switching effect. Section 9 explores these models, and Section 10 sets out some directions for future research.

\section{Models of exchange rates and relative prices}

In this and the next three sections, I examine some simple "new open economy macroeconomic" models. These models are fully integrated equilibrium models in which households and firms make optimal choices, but in which some nominal prices are not completely responsive to shocks.

There are two countries in the "general" model. I will assume that there is a single period, though most of the results I discuss carry over to a multi-period framework. I assume households in the home country maximize:

$$
U=\frac{1}{1-\rho} C^{1-\rho}+\chi \ln \left(\frac{M^{D}}{P}\right)-\psi L
$$


$C$ is a consumption aggregate. Households consume goods produced in the home country and in the foreign country. Assume preferences are homothetic (so consumption aggregates and price indexes are defined.)

Real balances, $\frac{M^{D}}{P}$, appear in the utility function, where $P$ is the optimal price index. Households get disutility from work, $L$.

Foreign households are assumed to have similar utility functions:

$$
U^{*}=\frac{1}{1-\rho} C^{* 1-\rho}+\chi \ln \left(\frac{M^{D^{*}}}{P^{*}}\right)-\psi L^{*}
$$

Starred $(*)$ variables are the foreign counterparts to the home-country variables.

Money is supplied exogenously through transfers. In equilibrium we have money supply equals money demand in each country: $M=M^{D}$, and $M^{*}=M^{D^{*}}$. The money supplies are random (as are productivity shocks introduced shortly.)

I will assume there are financial markets of the type discussed in Devereux and Engel (2001). Specifically, there are nominal bonds traded prior to the realization of the state that have payoffs specific to each possible state of the world. Most of the models we consider have home and foreign consumers facing different prices for the same good on spot markets. That is, the markets are segmented. We assume that it is impossible to make state-contingent trades that allow payoffs in physical goods, as that would allow households to get around paying the price set in their market. Instead, payoffs are specified in nominal terms. Optimal contracts ensure that the marginal utility from an additional unit of currency is proportional between home and foreign consumers in all states (where I have assumed the constant of proportionality is one):

$$
\frac{C^{-\rho}}{P}=\frac{C^{*-\rho}}{S P^{*}}
$$

$S$ is the nominal exchange rate, expressed as the home currency price of foreign currency. 
Even though there is a nominal bond traded for each state of the world, markets are not complete because the goods markets are segmented nationally. If the same good sells for different prices in different markets, households cannot "arbitrage" the goods market. As a result, risk sharing is not perfect unless purchasing power parity holds $\left(P=S P^{*}\right)$.

The assumption that so many nominal assets are traded is, of course, unrealistic. It is a useful benchmark, and here it allows us to arrive at a simple flexible model that can be used to analyze relativeprice effects in general equilibrium. We can reproduce Friedman's claim that nominal exchange rate flexibility allows desirable relative price adjustments to occur rapidly under his assumption of nominal prices fixed in producer's currencies, but we can also analyze other assumptions about how prices are set.

The following equilibrium conditions emerge using the first-order conditions for the household optimization problem:

$$
\begin{array}{ll}
M=\chi P C^{\rho} & M^{*}=\chi P^{*} C^{* \rho} \\
W=\psi P C^{\rho} & W^{*}=\psi P^{*} C^{* \rho}
\end{array}
$$

Here, $W$ and $W^{*}$ are the home and foreign wage, respectively.

This framework, while making very specific assumptions about preferences, has the advantage that it is easy to analyze under a variety of assumptions about goods pricing, and about preferences over goods. We can derive a solution for the nominal exchange rate that does not depend on any assumptions about the production side of the economy, about how nominal prices are set, or without making any further assumption on consumption utility:

$$
S=\frac{M}{M^{*}}
$$

Now we turn to the production side of the economy. There are a large number of goods produced in each country, each by a monopolist. We will initially consider models in which output for each firm $i$ 
is produced using only a labor input: $Y_{i}=\eta L_{i}$, and $Y_{i}^{*}=\eta^{*} L_{i}^{*} \cdot \eta\left(\eta^{*}\right)$ is a productivity shock that is common to all home (foreign) firms. We will consider a variety of possible assumptions about how prices are set. Prices may be flexible - that is, set with full information about the state. Or, in the new open economy models, firms must set nominal prices in some currency prior to knowledge about the state.

\section{Flexible Nominal Prices}

It is helpful first to examine some of the properties of this model under completely flexible nominal prices. We shall assume home and foreign households have identical CES preferences over home and foreign aggregates. Each of these aggregates is in turn a CES function over the individual goods produced in the home and foreign country, respectively. Firms face constant elasticity demand curves, and therefore set prices as a constant mark-up over unit costs. We allow firms to discriminate across home and foreign markets. But under our assumptions about preferences and about financial markets, when PPP holds (under flexible prices or under PCP), firms choose the same price for home and foreign consumers.

Aggregating across all home firms, we get

$$
P_{H}=\mu W / \eta,
$$

where $P_{H}$ is the home currency price of home goods, and $\mu>1$ is the mark-up. We have also $P_{H}=S P_{H}^{*}$, where $P_{H}^{*}$ is the foreign-currency price of home goods. Likewise,

$$
P_{F}^{*}=\mu W^{*} / \eta^{*}
$$

and $P_{F}=S P_{F}^{*}$.

We can also derive these equations for nominal wages in equilibrium:

5 One of the models we examine later will have an iceberg transportation cost for shipping goods overseas. We will also consider models in which intermediate goods are used as inputs into final goods production. 


$$
W=\frac{\psi}{\chi} M
$$

$W^{*}=\frac{\psi}{\chi} M^{*}$

It follows from the equilibrium conditions that

$$
\frac{P_{H}}{P_{F}}=\frac{P_{H}^{*}}{P_{F}^{*}}=\frac{\eta^{*}}{\eta} .
$$

The relative price of home goods falls when there is an increase in $\eta$. When productivity in home firms increases, the cost per unit of home goods declines. Those costs savings are passed onto to consumer in the form of lower prices.

I will not undertake a formal welfare analysis of the models presented here. Instead, I will focus on what turns out to be a critical aspect of the welfare analysis: the extent to which an exchange rate regime is beneficial in achieving the adjustment of the price of home goods relative to foreign goods. Under the Friedman framework, exchange-rate flexibility allows immediate adjustment of that relative price in response to real shocks. But, as we shall see, that finding is a special case that depends critically on how Friedman assumes nominal goods prices are set.

\section{Sticky Nominal Prices: PCP Case}

Now consider the model when firms must set nominal prices in advance. In the oneperiod framework here, this means that prices are set in advance of knowledge of the preference shocks and money supply realizations. Perhaps there are menu costs or some other sorts of costs that make it more profitable to set a non-state-contingent nominal price. First we take up the case in which firms set prices in their own currencies. That is, home firms set prices in the home currency, whether for sale to home or foreign households. We call this the PCP case. The law of one price holds for goods sold at home and in the foreign country, because, as we noted above, under our assumptions about preferences and financial markets firms do not price discriminate. 
It follows that

$$
\frac{P_{H}}{P_{F}}=\frac{P_{H}^{*}}{P_{F}^{*}}=\frac{P_{H}}{S P_{F}^{*}}
$$

Under the PCP assumption, both $P_{H}$ and $P_{F}^{*}$ are fixed ex ante and do not respond to shocks to demand or money supply. Define $\kappa \equiv \frac{P_{H}}{P_{F}^{*}}$. Because these nominal prices are set in advance of the realization of the state, $\kappa$ does not depend on the outcomes of the random variables. Then the relative price of home to foreign goods varies inversely with the exchange rate:

$$
\frac{P_{H}}{P_{F}}=\frac{\kappa}{S}
$$

Substituting in the expression for the equilibrium exchange rate, we get under PCP pricing:

$$
\frac{P_{H}}{P_{F}}=\kappa \frac{M^{*}}{M}
$$

Here we can see the gist of Friedman's argument for flexible exchange rates. If the exchange rate were fixed, there would be no channel to translate real demand shocks into a relative price change. That is, if the exchange rate were held constant at a value of $\bar{S}$, the relative price of home to foreign goods would not depend on the shocks that hit the economy:

$$
\frac{P_{H}}{P_{F}}=\frac{\kappa}{\bar{S}}
$$

But with exchange-rate flexibility and the correct monetary policy, the real productivity shocks can be translated precisely into the same relative price effect that occurs under flexible prices. With the monetary policy rules $M=\frac{\chi \eta}{\psi \mu} P_{H}$, and $M^{*}=\frac{\chi \eta^{*}}{\psi \mu} P_{F}^{*}$, the relative price will equal exactly its value under flexible prices:

$$
\frac{P_{H}}{P_{F}}=\frac{P_{H}^{*}}{P_{F}^{*}}=\frac{\eta^{*}}{\eta}
$$


In fact, allocations are identical under PCP with these monetary rules, and under flexible prices. That is, very much in accord with Friedman's intuition: flexible exchange rates are a perfect substitute for flexible goods prices in the presence of real shocks.

Moreover, in the models of OR (1998, 2000a), mimicking the flexible price allocation is the constrained globally efficient monetary policy. While the flexible-price equilibrium itself is not Pareto efficient (because of the monopoly distortions), optimal monetary policy can do no better than to replicate the flexible-price allocation.

The monetary policy I set out above is not only the policy that would be set by a global central planner. It is, as OR (2000a) show, the policy that self-interested national economic planners would follow. That is, there is no gain to international monetary coordination. Central banks following policies that maximize their own country's welfare can achieve the constrained globally efficient outcome. Thus, a system in which central bankers do not cooperate at all and allow the exchange rate to float freely is optimal, as Friedman claimed.

This model, however, has implications that seem counterfactual: that exchange rate changes are passed through one-for-one into consumer prices, and that the law of one price holds for all goods. It is this characteristic of the model that has led some researchers to consider the local-currency pricing version of the sticky-nominal price model.

\section{Sticky Prices: LCP Case}

An alternative model for price setting is that firms set prices in the currency of consumers of the product. That is, when a home firm sells in the home market it sets prices in the home currency. But for sales to the foreign market, it sets prices in the foreign currency. We call this the "LCP" (for "local currency pricing") case.

\footnotetext{
${ }^{6}$ OR $(1998,2000 a)$ have delicate sets of assumptions on preferences and market structure that insure that markets are actually complete. But OR (2001) show that these basic conclusions are to a first order robust to market incompleteness.
} 
It follows immediately in this case that a flexible nominal exchange rate cannot achieve the optimal relative price adjustment. $P_{h}$ and $P_{f}$ are both set in the domestic currency and do not respond to contemporaneous shocks. We cannot replicate the flexible-price solution of $\frac{P_{H}}{P_{F}}=\frac{P_{H}^{*}}{P_{F}^{*}}=\frac{\eta^{*}}{\eta}$ with flexible exchange rates, no matter what the monetary policy. In fact, Devereux and Engel (2001) go further and demonstrate that the optimal monetary policy in this case delivers fixed exchange rates. put another way, if the foreign country is following optimal monetary policy, while the home country is using the exchange rate as its policy instrument, the optimal exchange rate policy is to fix.

There is a simple way to understand the striking difference in optimal policy in the PCP world versus the LCP world. There are two types of deviations from efficiency which monetary policy might be able to rectify in a sticky-price world. One is that relative prices might not respond in the correct way to real shocks, so that we might not achieve $\frac{P_{H}}{P_{F}}=\frac{P_{H}^{*}}{P_{F}^{*}}=\frac{\eta^{*}}{\eta}$. In the absence of optimal relative price changes, consumers do not receive the correct signals and do not alter their demand for goods in the appropriate way when real shocks hit. As a consequence, resources will not be allocated efficiently.

The other type of inefficiency comes because deviations from purchasing power parity lead to incomplete risk sharing. As noted above, with a complete set of nominal contingent claims traded, in equilibrium $\frac{C^{-\rho}}{P}=\frac{C^{*-\rho}}{S P^{*}}$. Asset markets do not deliver complete risk sharing unless purchasing power parity holds, $P=S P^{*}$.

When prices are set in producers' currencies (PCP), purchasing power parity does hold, so asset markets do deliver complete risk sharing. In that case, monetary policy can be devoted entirely toward

\footnotetext{
${ }^{7}$ Bacchetta and van Wincoop (2000) and Devereux and Engel (1998) also examine exchange-rate rules with localcurrency pricing. However, those analyses do not examine the real shocks that are at the heart of the issues we discuss here.
} 
ensuring that relative prices respond in the appropriate way to real shocks. But, of course, exchange rate flexibility is needed to deliver the relative price response.

Under local currency pricing, relative prices simply cannot change in the short run in response to real shocks. It is useless for monetary policy makers to devote any effort to achieving an efficient relative price response. But, under LCP pricing, both $P$ and $P^{*}$ are predetermined and not affected by real shocks. If the nominal exchange rate is fixed so that purchasing power parity holds, $S=\frac{P}{P^{*}}$, then asset markets will achieve complete risk sharing.

This model is designed to highlight the role of expenditure switching and deviations from the law of one price for determining optimal monetary policy. The conclusion that fixed exchange rates are optimal, though, arises from some special features of the model: identical preferences, all goods are traded, and a nominal state-contingent bond traded for every state of the world. Under these assumptions, it is optimal to target world output, and, with fixed exchange rates, allow financial markets to share the risk that arises from idiosyncratic shocks.

More generally, there might be a tradeoff between the objective of monetary independence and the goal of minimizing deviations from the law of one price. Suppose that in each economy there is a sector that produces nontraded goods, and there are productivity shocks arising in the nontraded sector. On the one hand, it might be desirable to use monetary policy in this case to target local shocks. But such independent monetary policy will lead to nominal exchange rate changes that imply deviations from the law of one price for traded goods. These deviations would induce idiosyncratic risk in traded goods consumption.

Corsetti and Pesenti (2001) develop a model of "partial" pass-through of exchange rates to final consumer prices. Ex ante, firms may pass-through only a fraction $\lambda$ (taken to be exogenous) of any exchange rate change to consumer prices. The PCP model is one extreme in which $\lambda=1$, and the LCP is the other extreme in which $\lambda=0$. They examine optimal monetary policy, and the optimal degree of exchange-rate flexibility in this framework. Since Corsetti and Pesenti assume goods are sold directly to 
consumers (as do OR, and Devereux and Engel), it seems as though the empirically relevant case is the one in which $\lambda$ is nearly zero since pass-through to consumer prices is very small in the short run.

Corsetti and Pesenti show in their model that optimal policy minimizes a function of the "output gap" and deviations from the law of one price. The output gap is "the distance between actual and equilibrium employment levels." It is not always the case that eliminating the output gap is the optimal feasible policy. Corsetti and Pesenti's theorem implies that policy makers can improve welfare by using monetary policy to help eliminate deviations from the law of one price. Sometimes there is tension between that goal and the goal of eliminating the output gap.

\section{Empirical Evidence on Deviations from the Law of One Price}

The PCP model and the LCP model differ clearly in one empirical prediction. The PCP model predicts that the law of one price holds for consumer goods, while the LCP model predicts that it fails. Under the LCP model the (log) relative price of good $i$ in the home country compared to the foreign

country, $p_{i}-s-p_{i}^{*}$, varies as the nominal exchange rate changes, while in the PCP model this relative price is unaffected by nominal exchange rate movements.

That the law of one price (which I shall abbreviate as LOOP in this and subsequent sections) fails for traded goods prices is a well-established empirical fact. (See for example, Isard (1977) and Kravis and Lipsey (1978). The recent pricing to market literature, surveyed by Goldberg and Knetter (1997), has documented the lack of full response of import prices to exchange rate changes.) This literature has focused on import and export prices, not on the price of consumer goods. That distinction is important, as will become apparent in subsequent sections of this paper.

Some more recent work has focused on the failure of LOOP for consumer goods. That literature has documented not only that LOOP fails, but that its failure is large.

To say that the failure is "large" requires some metric for judging the size of the deviations from LOOP. One approach, in Engel (1993), was to compare the variance of deviations from LOOP, (that is 
$\operatorname{Var}\left(\Delta\left(p_{i}-s-p_{i}^{*}\right)\right)$, where $\Delta$ is the time difference) to the variance of relative price changes between goods within a single country $\left(\operatorname{Var}\left(\Delta\left(p_{i}-p_{j}\right)\right)\right.$, where $i$ and $j$ are different products.) The idea is to understand what causes the observed large movements in real exchange rates between industrialized nations. One possibility is that real exchange rate movements are due largely to deviations from LOOP. But there are major competing theories that assume LOOP holds, and attribute real exchange rate changes to relative price changes among different goods. The most prominent of those theories posits that the real exchange rate changes between two countries as the price of nontraded goods to traded goods changes. So, if $p_{N}-p_{T}$ rises relative to $p_{N}^{*}-p_{T}^{*}$ (home country $(\log )$ price of nontraded goods relative to traded goods rises relative to the foreign country (log) relative price), the home country price level will rise relative to the foreign country level. That is, there will be a home real appreciation. Another, somewhat less prominent, theory is that real exchange rates fluctuate because CPIs weight goods differently in different countries. Even if all goods are traded and LOOP holds for all goods, real exchange rates fluctuate as relative prices change. For example, if the French heavily weight wine in their CPI, then their CPI will rise relative to CPIs in other countries when the price of wine relative to other goods increases.

Engel (1993) compares $\operatorname{Var}\left(\Delta\left(p_{i}-s-p_{i}^{*}\right)\right)$ to $\operatorname{Var}\left(\Delta\left(p_{i}-p_{j}\right)\right)$ in some industrialized countries, looking at 1-, 3-, 6- and 12-month horizons. For some measures, the consumer goods are fairly narrowly defined (potatoes, televisions, wine), although for some other measures the goods are quite aggregated (food, services, energy, rent.) That paper simply tabulates $\operatorname{Var}\left(\Delta\left(p_{i}-s-p_{i}^{*}\right)\right)$ for all goods and countries, and $\operatorname{Var}\left(\Delta\left(p_{i}-p_{j}\right)\right)$ for all goods and countries, and compares their sizes. In general, the measures of $\operatorname{Var}\left(\Delta\left(p_{i}-s-p_{i}^{*}\right)\right)$ tend to be much larger than $\operatorname{Var}\left(\Delta\left(p_{i}-p_{j}\right)\right)$ at all horizons. The median value of $\operatorname{Var}\left(\Delta\left(p_{i}-s-p_{i}^{*}\right)\right)$ is about 6 or 7 times as large as the median value of $\operatorname{Var}\left(\Delta\left(p_{i}-p_{j}\right)\right)$ for all measures at all horizons. 
Rogers and Jenkins (1995) extend this analysis, with a focus on U.S.-Canadian consumer prices. They confirm the large deviations from the law of one price, and in addition find the deviations are very persistent.

Engel (1999) decomposes real exchange rate variation into a component attributable to deviations from LOOP, and a component attributable to changes in the relative price of nontraded goods. Consider a price index for a country that is a geometric weighted average of traded and non-traded goods prices:

$$
p_{t}=(1-\alpha) p_{t}^{T}+\alpha p_{t}^{N}
$$

We can also write

$$
p_{t}^{*}=(1-\beta) p_{t}^{T *}+\beta p_{t}^{N *}
$$

Then the real exchange rate is given by:

$$
q_{t}=x_{t}+y_{t}
$$

where $q_{t} \equiv_{t}+p_{t}^{*}-p_{t}, x_{t} \equiv s_{t}+p_{t}^{T *}-p_{t}^{T}$, and $y_{t} \equiv \beta\left(p_{t}^{N^{*}}-p_{t}^{T *}\right)-\alpha\left(p_{t}^{N}-p_{t}^{T}\right)$.

The log of the real exchange rate is composed of two parts: the relative price of traded goods between the countries, $x_{t}$; and a component that is a weighted difference of the relative price of nontraded to traded goods prices in each country, $y_{t}$. Engel (1999) then decomposes the mean-squared error of changes in U.S. real exchange rates into parts attributable to $x_{t}$ and $y_{t}$ (and a part attributed to their comovement, which is small) at different horizons. That study uses four separate measures of prices, and finds that the deviations from LOOP account for over $90 \%$ of movements in U.S. real exchange rates relative to almost all countries at all horizons for all measures.

Here I replicate and extend some of that analysis, using consumer price data from the OECD Main Economic Indicators (available from Datastream.) Data are monthly (from 1973:12 to 2001:1) on four components of the consumer price index: food, all commodities less food, rent, and all services less 


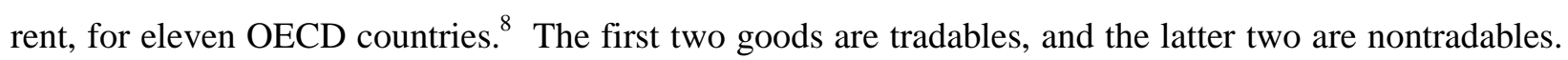
I construct price indexes for a consumer that has Cobb-Douglas preferences and weights these items with the same weights they receive in the 2001 U.S. consumer price index. ${ }^{2}$ In terms of the formula above, the weights $\alpha$ and $\beta$ are set equal to 0.587 for all countries. In practice, the U.S. weight for nontraded goods is higher than for almost all OECD countries, but this should only bias the results in favor of finding a significant role for the relative price of nontraded goods (the $y_{t}$ component.)

The constructed $q_{t}, x_{t}$, and $y_{t}$ are all very persistent. Even though there are 27 years of monthly data, an Augmented Dickey-Fuller test is able to reject a unit root at the 5 percent level for only 9 of the $55 q_{t}$ series, 9 of the $55 x_{t}$ series, and 8 of the $55 y_{t}$ series. At the one percent level, there are rejections only in one case for each of the three series. 10 All of the series had first-order serial correlation over 0.90, and except in a few cases, over 0.96. So, in examining movements in these series, it makes sense to look at changes rather than levels.

Figure 1 plots $\frac{\operatorname{MSE}\left(x_{t}-x_{t-j}\right)}{M S E\left(x_{t}-x_{t-j}\right)+M S E\left(y_{t}-y_{t-j}\right)}$ for $j=1,2, \ldots, 18$, where $M S E$ stands for mean-squared error. Engel (1999) presents similar plots using this data, but only for 5 countries, and only for U.S. real exchange rates. Any variance or mean-squared error decomposition must find a way to deal with comovements. Here, we leave the comovements of $x_{t}$ and $y_{t}$ out of both the numerator and denominator of the MSE ratios. In practice the comovements account for very little of the mean-squared error of real exchange rate changes. The correlation of the series generally was highest in absolute value at shorter horizons, but at those horizons the correlation was almost always negative - so the sum of the variances of $x_{t}$ and $y_{t}$ is greater than the variance of $q_{t}$.

\footnotetext{
${ }^{8}$ U.S., Canada, Japan, France, Italy, Switzerland, Belgium, Norway, Spain, Denmark, and the Netherlands.

${ }^{9}$ Weights: .157 for food; .256 for commodities less food; .312 for rent; .275 for services less rent.

${ }^{10}$ All of the ADF tests included a constant, no time trend, and three lags.
} 
The decompositions shown in Figure 1 for the U.S. real exchange rate series confirm the findings of Engel (1999). Nearly all of the movements in real exchange rates are attributed to $x_{t}$, the component that measures deviations from the law of one price. For all but the U.S./Canada rate, $x_{t}$ 's share of the mean-squared error is above 0.90 at all horizons. Usually it is above 0.95 . Only in for the U.S./Canada rate does it dip below 0.90 at the longer horizons, but then only to 0.893 for 18 -month changes.

A similar finding holds for cross-continental real exchange rates - that is, Japanese (relative to North America and Europe) and Canadian (relative to Europe) real exchange rates. The $x_{t}$ component accounts for over 90 percent of the MSE share for all real exchange rates at all horizons. 1 Usually the share is well over 95 percent.

The story for within-Europe real exchange rates is only slightly different. While $x_{t}$ 's share is often less than 90 percent, for 19 of the 28 European country pairs, $x_{t}$ 's share is never less than 80 percent at all horizons. The nine pairs where $x_{t}$ 's share falls below 0.80, and the range at all horizons for $x_{t}$ 's share for those country pairs are: Spain-Italy, 0.75-0.86; Denmark-France, 0.68-0.87; NorwayNetherlands, 0.73-0.88; Belgium-Netherlands, 0.67-0.89; Switzerland-Netherlands, 0.74-0.89; DenmarkNetherlands, 0.59-0.71; Denmark-Norway, 0.73-0.89; Denmark-Belgium, 0.63-0.71; and DenmarkSwitzerland, 0.77-0.89.

The fact that the deviations from LOOP are a slightly smaller share of real exchange rate movements for intra-European country pairs suggests that perhaps the deviations from LOOP are not really attributable to sticky consumer prices. Perhaps the LOOP deviations arise because transportation costs cause imperfect integration of markets. The somewhat smaller failures of LOOP for the European pairs might reflect the fact that transportation costs are lower for within-European trade than crosscontinental trade. On the other hand, during the period 1974-2001, intra-European nominal exchange rates have been less volatile than the cross-continental exchange rates. So, the fact that deviations from

\footnotetext{
${ }^{11}$ Except for the Danish-Canadian share at the 1-month horizon, where the share is 0.893 .
} 
LOOP are smaller within Europe is consistent with sticky nominal consumer prices and deviations arising from nominal exchange rate fluctuations. The next section helps to shed some light on this question.

Betts and Kehoe (2001) recently have performed similar decompositions for a large number of countries, finding somewhat more evidence that the relative price of nontraded goods drives real exchange rates. However, there are two reasons why their results should be treated with a bit of caution. They measure $q_{t}$, the real exchange rate, using relative consumer price indexes in essentially the same way as I do. ${ }^{2}$ But their measure of $x_{t}$ is not a CPI measure of traded goods. Instead they take $x_{t}$ to be the relative producer price indexes across countries (that is, $s+\log \left(P P I^{*}\right)-\log (P P I)$.) This measure of $x_{t}$ might vary over time even if the law of one price held for all traded goods and CPI weights for traded goods are identical. That is because it measures $x_{t}$ using output weights rather than consumption weights. Output weights can be very different across countries even when CPI weights are not. A more substantial reason why Betts and Kehoe attribute more of real exchange rate movements to $y_{t}$ is that they measure $y_{t}$ as simply $q_{t}-x_{t}$. As I argued in Engel (1999), where I also employed this measure of $y_{t}$ (as one of the four measures of $y_{t}$ I considered), there is a serious bias introduced by measurement error in this case. Since $x_{t}$ and $q_{t}$ are measured from different pricing surveys (PPI and CPI), where no effort is made to reconcile the pricing errors, there will be largely uncorrelated measurement errors in the two series. This in turn implies there will be a potentially large negative correlation between the measure of $x_{t}$ and the measure of $y_{t}\left(=q_{t}-x_{t}\right)$. Indeed in Engel (1999), I found that $x_{t}$ and $y_{t}$ measured in this way were highly negatively correlated. Decomposing the real exchange rate into $x_{t}$ and $y_{t}$ components is problematic because one must find a way to deal with the negative correlation. Although their results are similar to mine, Betts and Kehoe do attribute a larger share of the variance of annual changes in real

\footnotetext{
${ }^{12}$ One difference is that I construct real exchange rates for consumers who weight the four main components with equal weights in all countries, while they simply used published CPIs. Thus, their real exchange rate changes may reflect changes in relative prices that get reflected in real exchange rates because goods receive different weights across national CPIs.
} 
exchange rates to the nontraded $\left(y_{t}\right)$ even for the countries that I consider here. I do not find that the difference in our findings is attributable to differences in methodology, and so I must conclude that they arise from the difference in the way we measure the price of tradable goods.

In essence, Devereux and Engel (2001) take the evidence against the law of one price for consumer goods as support for the position that nominal exchange rate changes are not passed through to consumer prices because of local-currency pricing. But there are other ways to interpret the evidence that do not rely on LCP behavior. We turn to a few of these alternatives.

\section{Shipping Costs}

One explanation for why the law of one price fails is that home and foreign consumers are consuming slightly different products. That is, suppose a given product can be produced in both the home and foreign country. Let the per unit iceberg transport cost for exported goods be $\delta$, as in OR (2000b).

Let $P_{H}$ be the domestic currency price of the good in the home country, and $P_{F}^{*}$ be the foreign currency price of the good in the foreign country. The two goods are perfect substitutes for households. Then,

$$
\frac{1}{1+\delta} S P_{F}^{*} \leq P_{H} \leq(1+\delta) S P_{F}^{*}
$$

If the home price is within this band, there is no pass-through of exchange rates to domestic prices. On the edges of the band, pass-through is complete. But this model has the untenable implication that zero pass-through occurs only because there is no trade.

A more satisfactory version of the transportation costs theory is that there are two varieties of the good, one produced in the home country and the other produced in the foreign country. Assume CES utility (and no differences in tastes between home and foreign residents), and an elasticity of substitution between varieties greater than one. If the elasticity and the per-unit transport costs are high enough, foreign varieties may constitute a small share of overall consumption and thus a small share in the 
measured price of home-country consumption. The converse will characterize the foreign country. The law of one price may fail grossly for the price index of these two goods.

Let $P_{i}$ be the price of a particular good. However, $P_{i}$ is itself an index over the price of two varieties of the good - one produced at home and one in the foreign country. Suppose home and foreign households have the same preferences for the good:

$$
C_{i}=\left(\alpha C_{i H}^{\lambda-1 / \lambda}+(1-\alpha) C_{i F}^{\lambda-1 / \lambda}\right)^{\lambda / \lambda-1}
$$

where the $i$ subscript is for the good, of which there are two types: $H$ for home and $F$ for foreign. Let the per unit iceberg transport cost for exported goods be $\delta$. The home country producer is the only producer of the home variety, and the foreign producer the only producer of the foreign variety. The law of one price holds exclusive of transport costs. We have $P_{i H}^{*}=(1+\delta) P_{i H} / S$ and $P_{i F}=(1+\delta) S P_{i F}^{*}$. The rest of the macro model is the same as specified above.

$$
\text { Under flexible nominal prices, } \frac{P_{i H}}{P_{i F}} \text { and } \frac{P_{i H}^{*}}{P_{i F}^{*}} \text { respond to real shocks. If nominal prices are sticky }
$$

as in the Friedman framework of PCP, it is clear that a flexible exchange rate is necessary to achieve a desirable response of $\frac{P_{i H}}{P_{i F}}$ (or $\frac{P_{i H}^{*}}{P_{i F}^{*}}$ ) to real shocks. This framework potentially is also consistent with the observation that measured consumer prices do not respond much to exchange rate changes. We have:

$$
P_{i}=\left(\alpha^{\lambda} P_{i H}^{1-\lambda}+(1-\alpha)^{\lambda} P_{i F}^{1-\lambda}\right)^{1 / 1-\lambda}=\left(\alpha^{\lambda} P_{i H}^{1-\lambda}+(1-\alpha)^{\lambda}(1+\delta)^{1-\lambda} S^{1-\lambda} P_{i F}^{* 1-\lambda}\right)^{1 / 1-\lambda}
$$

The pass-through elasticity for the home country, for example, is

$$
\varepsilon=\frac{(1-\alpha)^{\lambda}(1+\delta)^{1-\lambda} S^{1-\lambda} P_{i F}^{* 1-\lambda}}{\alpha^{\lambda} P_{i H}^{1-\lambda}+(1-\alpha)^{\lambda}(1+\delta)^{1-\lambda} S^{1-\lambda} P_{i F}^{* 1-\lambda}}
$$

For $\lambda>1, \varepsilon \rightarrow 0$ as $\delta \rightarrow \infty$. If the cost of the foreign good is high enough, there will not be much effect of exchange rates on home consumer prices if the foreign good is a sufficiently high substitute for the domestic good. For foreign prices (in domestic currency terms): 


$$
S P_{i}^{*}=S\left(\alpha^{\lambda} P_{i H}^{*_{1}-\lambda}+(1-\alpha)^{\lambda} P_{i F}^{* 1-\lambda}\right)^{1 / 1-\lambda}=\left(\alpha^{\lambda}(1+\delta)^{1-\lambda} P_{i H}^{1-\lambda}+(1-\alpha)^{\lambda} S^{1-\lambda} P_{i F}^{* 1-\lambda}\right)^{1 / 1-\lambda}
$$

If shipping costs were zero, so $\delta=0$, the law of one price would hold for good $i$. That is, we would have $\frac{P_{i}}{S P_{i}^{*}}=1$. But as $\delta$ increases above zero, deviations from the law of one price for good $i$ (that is, for the index of the price of varieties $H$ and $F$ ) increase. Taking a Taylor series expansion, the variance of $\ln \left(\frac{P_{i}}{S P_{i}^{*}}\right)=p_{i}-s-p_{i}^{*} \quad$ equals approximately $\left(\frac{1}{\lambda-1}\right)^{2}\left(\frac{z-1}{z+1}\right)^{2} \operatorname{Var}(X)$, where $z=(1+\delta)^{\lambda-1}$, and $X=\left(\frac{1-\alpha}{\alpha}\right)^{\lambda}\left(\frac{P_{i H}}{S P_{i F}^{*}}\right)^{\lambda-1}$. As the shipping costs increase, the variance of $p_{i}-s-p_{i}^{*}$ increases (holding the variance of $X$ constant.)

Several studies have examined how the variations of deviations from LOOP are related to distance, which is taken to be a proxy for shipping costs. Engel and Rogers (1996) posit that the standard deviation of changes in $p_{i}-s-p_{i}^{*}$ is related to distance. Their comparison is made for 14 disaggregated CPI categories (food at home, food away from home, men's and boy's apparel, etc.); and, for 23 cities in North America - 9 Canadian cities and 14 U.S. cities. They found that deviations from LOOP were significantly related to distance between locations. But they also found that, even taking into account the distance effect, the deviations from LOOP were much larger when comparing goods prices between U.S. and Canadian cities than when comparing prices for city pairs within the U.S. or Canada. That is, there is a large "border effect."

Similar findings have been confirmed for U.S.-Japanese prices (Parsley and Wei (2001a)), and intra-European prices (Engel and Rogers (2001), and Parsley and Wei (2001b)). The Parsley and Wei studies have used data on very narrowly defined consumer goods (for example, box of facial tissue, men's jeans, imported whiskey.) Each of these studies confirms that distance between locations is a significant explanatory variable for the standard deviation of $p_{i}-s-p_{i}^{*}$. But these studies go further, and find that 
volatility of nominal exchange rates plays a much greater role in accounting for the volatility of deviations from the law of one price.

Here I shall present some evidence that is similar in spirit to the evidence presented in these papers. My traded goods price data is not nearly as disaggregated as the data in the other studies: I will use the OECD data on consumer prices for food, and for all commodities excluding food that I described in the previous section.

In Table 1, I report cross-section regressions, in which the dependent variable is the standard deviation of changes in $p_{i}-s-p_{i}^{*}$ (for food, and commodities less food.) (So, there are 55 observations in each cross-section regression, representing the standard deviation of $p_{i}-s-p_{i}^{*}$ for each of the 55 country pairs.) The first panel of Table 1 reports regressions for 1-month changes, and the bottom panel for 12-month changes. The "shipping costs" are captured by DIST, which measures the log of the distance between the capital cities. It is difficult to gauge the correct form of the nonlinear relationship between distance and shipping costs, especially over large inter-continental distances. So, the regressions also include a dummy variable that takes on a value of one if one of the countries in the country pair is Japan (JADUM), and another dummy if the country pair has one country in North America and another in Europe (ATLDUM).

For both food, and non-food goods, the coefficient on log distance is positive and highly significant for both 1-month and 12-month changes. This is in accord with the transportation cost theory of deviations from LOOP.

Another approach is to take bilateral trade volumes as a measure of integration between two countries. Table 1 reports regressions that use the $\log$ of bilateral trade volumes instead of the $\log$ of distance as an explanatory variable. ${ }^{13}$ Two sets of regressions are reported. The first are OLS in which the bilateral trade volumes are deflated by the product of GDPs of the trading pairs. The second are IV regressions in which the undeflated bilateral trade volumes are explained in a first stage by a gravity

\footnotetext{
${ }^{13}$ This data was taken from Andrew Rose's website, http://haas.berkeley.edu/ arose/RecRes.htm. It is the data used in Frankel and Rose (2001). I take the average of the log of bilateral trade for 1975, 1980, 1985, 1990 and 1995.
} 
model - using the log of distance, and the log of the product of GDPs as instruments. For both food, and non-food goods, the coefficient on log of trade is positive and significant for both 1-month and 12-month changes.

However, as was noted in the previous section, countries that are closer together, or that have higher (scaled) bilateral trade volumes, also tend to have lower nominal exchange rate volatility. So, the "transportation cost" effects that Table 1 reports may be overstating the value of distance or trade. In Table 2, the same regressions are run, but also using the standard deviation of the nominal exchange rate as an explanatory variable. In all cases, the standard deviation of the nominal exchange rate is highly significant. In comparison to Table 1 , the absolute values of the coefficients on the trade and distance variables fall greatly, and their statistical significance also falls.

Table 3 reports an analysis of variance for each of the regressions reported in Table 2. The purpose of Table 3 is to show how much of the "explained" variance of the dependent variable is attributable to the standard deviation of nominal exchange rates, the integration variable (distance or trade volumes), the dummy variables, and their interaction. Table 3 reveals that distance or trade volumes accounts for a small fraction of the explained variance in all of the reported regressions. In all eight of the twelve regressions, they account for one percent or less of the explained variance. In one regression they account for 16.4 per cent, and in the remaining three they account for less than ten percent. In contrast, in all of the regressions, the standard deviation of the nominal exchange rate accounts for a large fraction of the explained variance. In all but one case it is over fifty percent, and in most cases it is over eighty percent. So, even though distance or trade volumes are sometimes significant in explaining the standard deviation of $p_{i}-s-p_{i}^{*}$, they do not carry much of the load in explaining it.

In the transportation cost model, the behavior of nominal exchange rates plays no role in explaining the deviations from the law of one price. The deviations result from a real trading cost. The models make no mention of these costs differing across nominal exchange rate regimes. In the LCP model, by contrast, deviations from the law of one price are volatile precisely because nominal exchange 
rates are volatile. The empirical work cited above, and the new work reported here, shows there is a role for both models in explaining the deviations from the law of one price. But, the implication of the analysis of variance in Table 3 is that the proxies for trading costs account for a very small fraction of the variation in prices across countries compared to nominal exchange rate fluctuations.

These empirical studies certainly do not perfectly measure "transportation costs", or their effects on deviations from the law of one price. However, even if transportation costs were much more significant, this model actually does not support a strong "expenditure switching" effect. The reason there is so little pass-through of exchange rates to consumer prices in the home country in the transportation cost model is that foreign varieties are a small share of total consumption. In fact, $\varepsilon$ measures not only the elasticity of consumer prices with respect to a change in the price of foreign goods; it also measures the share of foreign goods in expenditures. So pass-through can only be small in this model if the expenditure share on foreign varieties is small. The case for floating rates is weak in this case. Floating rates might be needed to achieve optimal relative price adjustments, but those relative price adjustments are not very important to the functioning of the economy in this model.

In fact, Obstfeld and Rogoff (2000b) reason that the low pass-through to consumer prices could not be fully explained by transportation costs, and that some other factors must be at play.

\section{Non-traded Distribution Services and PCP}

One possible explanation for the apparent non-responsiveness of consumer prices to exchange rate changes is that CPIs measure a basket of both prices of consumer goods and the distribution services that bring the goods to consumers. The law of one price might very well hold for the actual physical good (as in PCP models), but the measured consumer price includes the price of the distribution service which is nontraded, and for which the law of one price need not hold. Recent examples of papers that have adopted this type of model are McCallum and Nelson (2000), Burstein, Neves and Rebelo (2000), and 
Burstein, Eichenbaum, and Rebelo (2002). .4 None of these papers provide direct evidence on the role of distribution costs in accounting for real exchange rate changes.

Let the home price of imported good $i$ be a composite of a traded goods price $\bar{P}_{i}$ for which the law of one price holds, $\bar{P}_{i}=S \bar{P}_{i}^{*}$, and the price of a nontraded distribution service, $P_{i S}$. If output of the final consumer product is a CES function of the traded good and the distribution service (with elasticity equal to $\lambda$ ), the price of the final product can be written as:

$$
P_{i}=\left(\alpha^{\lambda} P_{i S}^{1-\lambda}+(1-\alpha)^{\lambda} \bar{P}_{i}^{1-\lambda}\right)^{1 / 1-\lambda}=\left(\alpha^{\lambda} P_{i S}^{1-\lambda}+(1-\alpha)^{\lambda} S^{1-\lambda} \bar{P}_{i}^{* 1-\lambda}\right)^{1 / 1-\lambda} .
$$

If $\bar{P}_{i}^{*}$ is fixed in foreign currency terms, the pass-through of exchange rates is given by:

$$
\varepsilon=\frac{(1-\alpha)^{\lambda} S^{1-\lambda} \bar{P}_{i}^{* 1-\lambda}}{\alpha^{\lambda} P_{i S}^{1-\lambda}+(1-\alpha)^{\lambda} S^{1-\lambda} \bar{P}_{i}^{* 1-\lambda}} .
$$

As $\alpha \rightarrow 1, \varepsilon \rightarrow 0$. That is, as the share of the nontraded distribution service increases toward unity, the pass-through elasticity falls toward zero.

We cannot usually observe $\bar{P}_{i}$ and $\bar{P}_{i}^{*}$ directly, but we might be able to examine this hypothesis using only measures of the consumer price, and a measure of the price of services. To simplify matters, let the production function be Cobb-Douglas (so $\lambda \rightarrow 1$ in (8.1).) Equation (8.2) expresses the price of good $i$ in the home compared to the foreign country (where lower case letters are logs, and where the $i$ subscripts are dropped):

$$
p-s-p^{*}=k+\alpha x+(1-\alpha) u
$$

where $\mathrm{k}$ is a constant; $\alpha$ is the cost share of nontraded distribution services; $x \equiv p_{s}-s-p_{s}^{*}$ is the price of services in the home country relative to the foreign country; and, $u \equiv \bar{p}-s-\bar{p}^{*}$ is the price deviation for the traded good. Under the null of the law of one price, $u$ should literally be zero, but the null might

\footnotetext{
${ }^{14}$ The model of OR (2000a) could be interpreted this way. The "final good" in that type of model is a composite of a traded home-produced good, a traded foreign-produced good and a nontraded distribution service.
} 
allow for a small i.i.d. error. So, equation (8.2) could be estimated. It should have a good fit, and yield a tight estimate of $\alpha$ if the distribution cost model is true.

But estimating this equation is not useful for distinguishing between the model in which prices are equalized for the traded good, and the model in which there is local currency pricing for the traded good. To allow for this alternative, let $u=-\gamma s+\varepsilon$. Under LOOP for the traded good, $\gamma=0$. Under LCP, $\gamma=1.1-\gamma$ is the degree of pass-through. Assume that $\varepsilon$ is uncorrelated with $s$, and has a small variance. Also, define $v=p_{s}-p_{s}^{*}$, and assume for purposes of exposition that it is also uncorrelated with $s$. Then $x \equiv v-s$. Under these assumptions, the probability limit of the OLS estimate of $\alpha$ from equation (8.2) is given by:

$$
\alpha+\frac{(1-\alpha)[\operatorname{Cov}(\varepsilon, v)+\mathcal{V a r}(s)]}{\operatorname{Var}(v)+\operatorname{Var}(s)}
$$

Under the hypothesis that the law of one price holds for the traded good $(\gamma=0)$, the asymptotic bias is small since $\operatorname{Cov}(\varepsilon, v) / \operatorname{Var}(s)$ is likely to be small. But when $\gamma=1$, the asymptotic bias of the estimate of $\alpha$ from this regression could be large. As $\operatorname{Var}(s)$ gets large, the probability limit of the estimate of $\alpha$ approaches $\alpha+(1-\alpha)=1$. Under the alternative of LCP, estimating equation (8.2) would return a large estimate of $\alpha$. The equation would fit well, and appear to attribute most of the variation of $p-s-p^{*}$ to the relative services component. Estimating (8.2) is not a good way to test for the model in which the LOOP holds for the traded good (and the services component accounts for all of the deviations in the CPI prices across countries), versus the LCP model.

Suppose, however, we could group $u$ with $x$ and estimate equation (8.3):

$$
p-s-p^{*}=k+\alpha(x-u)+u
$$

The probability limit of the estimate of $\alpha$ from this regression is given by:

$$
\alpha+\frac{\operatorname{Cov}(\varepsilon, v)-\operatorname{Var}(\varepsilon)-\gamma(1-\gamma) \gamma \operatorname{Var}(s)}{\operatorname{Var}(v)+\operatorname{Var}(\varepsilon)-2 \operatorname{Cov}(\varepsilon, v)+(1-\gamma)^{2} \operatorname{Var}(s)} .
$$


When $\gamma=0$, the asymptotic bias is small because $\operatorname{Var}(s)$ is large relative to the other variances and covariances. The R-squared from the regression should be high because $x-u=v-\varepsilon+s$ in this case, which has a high variance relative to the regression error, $u=\varepsilon$. But under LCP, $\gamma=1$, the asymptotic bias is much higher, and likely to be negative if $\operatorname{Cov}(\varepsilon, v)$ is near zero. Moreover, the R-squared will be low since $x-u=v-\varepsilon$ has small variance, and the regression error, $u=-s+\varepsilon$ has large variance. So, if LCP were important, the coefficient estimate and R-squared from this regression would be very different than if LOOP held for the traded good. This might be a useful approach to distinguish the models.

Fortunately, we can observe $x-u$ up to a constant of proportionality, because $x-u=\frac{1}{1-\alpha}\left(p_{s}-p-\left(p_{s}^{*}-p^{*}\right)\right)$. Substituting into equation (8.3), we arrive at the equation we propose to estimate:

$$
p-s-p^{*}=k+\frac{\alpha}{1-\alpha}\left(p_{s}-p-\left(p_{s}^{*}-p^{*}\right)\right)+u \text {. }
$$

To sum up the previous discussion: Under the hypothesis that nontraded distribution services account for the observed deviations across countries in consumer prices, while LOOP holds well for the actual traded good, the slope coefficient in the regression should be strongly positive and the R-squared should be high. Alternatively, if there is LCP for the traded good, the slope coefficient is biased downward (and may be negative), and the R-squared will be low (especially if $\operatorname{Var}(s)$ is high.)

We do not observe the cost of the distribution services, $p_{s}$, directly. But we can use as a proxy the OECD prices of services (excluding rent) described above in Section 6. We use as our measure of the observable traded goods price, $p$, the traded goods price that was constructed from the OECD data on food prices and prices of non-food commodities.

As we noted above, the measures of $p-s-p^{*}$ are highly persistent for all 55 country pairs, and we fail to reject a unit root in almost all cases. Similarly, $p_{s}-p-\left(p_{s}^{*}-p^{*}\right)$ is persistent. We reject a 
unit root at the 5 percent level for only 9 of the 55 country pairs, and at the 1 percent level for only two. So, we will examine the relationship between changes in $p-s-p^{*}$ and changes in $p_{s}-p-\left(p_{s}^{*}-p^{*}\right)$. We regress 1-month (2-month, 3-month,..., 24-month) changes in $p-s-p^{*}$ on 1-month (2-month, 3-month,..., 24-month) changes in $p_{s}-p-\left(p_{s}^{*}-p^{*}\right)$.

Figure 2 presents plots of the estimated slope coefficient from the regressions for the 24 horizons, with one graph for each of the 55 country pairs. Figure 3 plots the R-squareds from those regressions.

The results indicate poor performance for the distribution services model at the shortest horizons. For horizons less than 6 months, there are no cases in which the coefficient is positive and the R-squared is greater than 0.07. In many instances, the coefficient on the relative price of services is negative. For all of the intra-European country pairs, which have low nominal exchange rate volatility, the coefficient is negative at horizons of one to six months. In some cases the R-squared is high (in the range of 0.15 to 0.45) in these regressions. As we would expect under LCP, the lowest R-squareds are for the country pairs that have the highest nominal exchange rate volatility - country pairs involving the U.S., Japan, and Canada with overseas partners.

At the longest horizons, the distribution services model fares only slightly better. It is still the case that the coefficient estimates is negative at the longer horizons for almost all of the European country pairs. Of the 28 European country pairs, only nine display positive coefficients at all of the horizons from 19 to 24 months. Two more have positive coefficients at the 23- and 24-month horizons. In only one of these eleven cases (Belgium-Norway) is the R-squared above 0.20. The distribution services model appears to explain a bit more for the 27 country pairs that are not intra-European. In fourteen cases, the regression coefficient is positive at all of the longer horizons (19 to 24 months), and in two additional cases it is positive for some of the longer horizons. Of these 16 country pairs with positive coefficient estimates at longer horizons, only three (Belgium-U.S., Belgium-Canada, and Netherlands-U.S.) have Rsquareds greater than 0.20 . 
Goldberg and Verboven (2001a) (hereinafter referred to as GV) have a related empirical study that appears to find much stronger evidence in favor of the distribution services approach. GV use extremely detailed data for automobile prices sold in five European countries. They have prices of specific models for 15 years, data on characteristics of the automobiles (horsepower, size, luxury features, etc.), production location of each model, and some data on income of buyers. They use tax data, and make use of data on import restrictions. In short, their data is comprehensive and much better than the data used here.

In essence, GV estimate a version of equation (8.2). However, they do not simply allow the deviation from the law of one price for the traded good to appear as an error term in the regression. They are not able to observe $u$. But they build a highly complex model of automobile demand, and pricing to market behavior of automobile producers. Combining these they use sophisticated nonlinear methods to come up with a measure of the desired degree of price discrimination by firms. Although this does not do justice to their work, in essence their empirical model could be expressed as an extension of (8.2):

$$
p-s-p^{*}=k+\alpha x+y+\eta
$$

Relative to (8.2), the $y$ term represents the sophisticated estimate of desired price discrimination by firms. The error term $\eta$ represents all the elements not captured by $y$, so $\eta \equiv(1-\alpha) u-y$.

The GV approach is a reasonable and very admirable attempt to deal with the unobservability of $u$. My hunch - and this obviously deserves further study - is that GV still do not capture the full degree of price discrimination. In fact, if producers are simply setting prices in local currencies (because, say, of menu costs), the model of GV will certainly underpredict the degree of desired local-currency price stability for the imported good. So the residual remaining in the GV regression will still be highly negatively correlated with $s$, and therefore highly positively correlated with $x$. As a result, GV will tend to attribute too much to the distribution services component, $x$.

GV believe they rule out the possibility of transitory price stickiness by estimating their equation in levels over a fifteen-year period - to capture the "long-run" pricing equation. However, real exchange 
rates are extremely persistent (see Rogoff, 1996). Chari, Kehoe, and McGrattan (2000), show that when price setting is asynchronized, the speed of adjustment can be very slow. Rogoff cites a half-life for the real exchange rate of 3-5 years. With such slow adjustment of prices, the fifteen year sample that GV use may not be sufficient to capture only long-run pricing behavior.

Even if the distribution services hypothesis is correct, it might imply that the role for nominal exchange rate flexibility is small. In this approach, the reason that nominal exchange rates have low passthrough to consumer prices is that the distribution services are a large component of the cost of consumer goods. As in the model with transportation costs, if the nontraded marketing services are such a large component of the cost of consumer goods that we barely observe any effect of exchange rate passthrough, then the physical import must not be a very important component of our consumer basket. Exchange-rate flexibility is desirable for achieving relative price adjustments, but these relative price adjustments may not be very significant. The cost of the physical traded good is a small component of the overall cost of consumer goods, so achieving the optimal relative price change for this component may not influence welfare much.

\section{Imports as Intermediate Goods}

Obstfeld (2001) models imported goods as intermediate products. They are combined with products produced locally to make final consumer goods (which are nontraded). There is complete passthrough of exchange rates to imported goods prices in this framework. That is, the price of imported goods is set in the producers' currencies, so the imported price varies one for one with the exchange rate. But imported goods are not sold directly to consumers. The price of the final good is set in the consumers' currencies.

This model, then, is completely consistent with the observation that consumer prices do not respond much to exchange rate changes in the short run. But there is still an important role for exchangerate flexibility in changing relative prices. The final goods producer faces a "sourcing" decision - to use

imported intermediates or locally produced intermediates. There is not perfect substitutability between 
the two, but there is some. ${ }^{15}$ So, a nominal exchange rate adjustment can change the price of imported relative to locally produced intermediates.

There is a single final consumer good, sold by a monopolist that buys intermediate inputs in competitive markets. The price of the final good in the home country is $P$, and it is fixed in homecurrency.

The cost of producing the good is not fixed ex ante. The cost is given by:

$$
\Gamma=\left(\alpha^{\lambda} P_{H}^{1-\lambda}+(1-\alpha)^{\lambda} S^{1-\lambda} P_{F}^{* 1-\lambda}\right)^{1 / 1-\lambda}
$$

Here, $P_{H}$ is the price of the home-produced intermediate good. That good is produced using a variety of labor inputs. In the Obstfeld set-up, each household is a monopoly supplier of a unique type of labor. Nominal wages are fixed ex ante. The intermediate goods market is competitive with free entry. The price, $P_{H}$, is in principle flexible but under competitive conditions it is equal to the ex ante fixed nominal wage. (In Obstfeld's model, there are no productivity shocks, but there are labor supply shocks. The labor input per unit of output is fixed at unity.)

Likewise, $P_{F}^{*}$ is the price of the foreign produced intermediate in the foreign currency. The structure of the foreign intermediate market is the same as in the home market, which implies that $P_{F}^{*}$ is fixed ex ante in the foreign currency. The home-currency price, $P_{F}=S P_{F}^{*}$, changes with the exchange rate.

Under flexible nominal prices, using the general model of section 2, we find

$$
\frac{P_{H}}{P_{F}}=\frac{P_{H}^{*}}{P_{F}^{*}}=\frac{\eta^{*}}{\eta} .
$$

(Here, an increase in $\eta$ represents an increase in home labor supply, which would reduce the wage and cost per unit of the home product under flexible prices and wages.)

\footnotetext{
${ }^{15}$ Specifically, in Obstfeld's framework there is a unitary elasticity of substitution.
} 
With fixed nominal wages, we have for example in the home country $\frac{P_{H}}{P_{F}}=\frac{P_{H}}{S P_{F}^{*}}$. Since $P_{H}$ and $P_{F}^{*}$ will be fixed under the market conditions described, we need exchange rate flexibility to allow relative price adjustment. Indeed, since $S=\frac{M}{M^{*}}$ with a suitably designed monetary policy of the form $M=k \eta$ and $M^{*}=k^{*} \eta^{*}$, the flexible price equilibrium can be mimicked. Indeed, Obstfeld demonstrates that prices and allocations are identical under flexible prices as under sticky nominal wages with this inward-looking monetary policy that has exchange rate flexibility 16

Obstfeld and Rogoff (2000) present evidence that shows there is much more pass-through of exchange rates to imported goods prices than to final consumer prices. While the pass-through is certainly not 100 per cent (as in the model just described), there appears to be a sufficient degree of pass through to allow for a significant expenditure-switching effect following from nominal exchange rate changes. Goldberg and Knetter (1997) and Goldberg and Campa (2001) offer evidence that while passthrough to import prices is far from complete, it is significantly greater than the degree of pass-through to final consumer prices.

An important aspect of the Obstfeld (2001) model is the idea that there are final goods producers or distributors who can substitute between locally produced and imported intermediates. Devereux, Engel and Tille (1999) take an approach that is quite similar to Obstfeld (2001). However they take the limiting case of the cost function in which the elasticity of substitution is zero. That is, their model can be interpreted as one in which the distributor combines imported goods and locally produced goods in fixed proportion. 17 In that case, of course, there is no possibility of substitution between imported goods and local goods when the exchange rate changes, even though there is complete pass-through of the exchange rate to imported prices.

\footnotetext{
${ }^{16}$ In fact, in terms of real variables and prices of output, the model is isomorphic to the PCP model of Obstfeld and Rogoff (2000a).

17 That is not exactly the set-up in Devereux, Engel and Tille, but there is little difference in substance between the model I describe here and their precise model.
} 
Potentially there are wealth effects from exchange rate changes in this case. The demand for imported goods is fixed because their price is fixed in consumers' currencies and the distributor cannot substitute toward locally produced goods. When the home currency depreciates, it raises the price that local distributors must pay for imported goods and lowers their profits. Foreign distributors have a windfall gain. In Devereux, Engel and Tille (1999), these profit effects are not consequential because of their assumption that there are state-contingent nominal bonds traded for each possible state. But Tille (2000) investigates the importance of these wealth effects on equilibrium demands when only non-state contingent bonds can be traded. These wealth effects, however, are a completely different channel through which exchange rates affect equilibrium than the relative price effects that are so important to the Friedman analysis.

The model of Devereux, Engel and Tille (1999) is best described as one in which imports are primarily branded final goods. The distributor cannot substitute any local product for that brand. That is, a Toyota dealer cannot substitute a Chevrolet Lumina for a Camry if the yen becomes too expensive. The Obstfeld (2001) model is best thought of as a model in which the consumer cannot differentiate between local and imported sources of inputs. Perhaps the typical product in this set up is auto parts. The automobile might itself be assembled in the country in which it is consumed (in fact, many Toyota Camrys purchased in the U.S. are manufactured in the U.S.), but using parts that could be imported or produced locally.

The empirical question is to what extent substitution occurs at some stage before the good reaches the consumer. For the question of exchange-rate flexibility, the key is whether substitution can occur between imported and local products. That is, if the U.K. is considering adopting the euro versus keeping an independent pound, the question is whether in response to a pound depreciation the British can substitute toward British goods. Let me clarify what by way of an example. Suppose the imported good is wine. If the euro appreciates relative to the pound and dollar and thereby raises the pound price of French wine (as in the PCP specification), then British might substitute away from French wine toward American wine. But for that margin of substitution, the flexibility of the pound/euro rate does not matter 
at all. Even if the pound/euro rate were fixed, the price of French wine would rise relative to American wine. The question is the degree to which a euro appreciation leads British distributors to substitute away from goods produced on the Continent toward U.K. produced goods. If a large degree of such substitution occurs (as in the Obstfeld (2001) model) then exchange-rate flexibility is desirable. If little such substitution occurs (as in Devereux, Engel and Tille (1999)), then there is not so strong a case for an independent currency with freely floating rates.

\section{Conclusions}

The famous case for flexible exchange rates advanced by Friedman (1953) is based on a view that appears at odds with empirical evidence. Friedman's approach assumes that nominal prices are set in producers' currencies, and exchange rate changes are passed through completely to final users of the goods. Thus an exchange rate change delivers a relative price adjustment between foreign and domestically produced goods.

Recent theoretical papers confirm Friedman's policy prescription under his assumption about goods pricing. Empirical evidence appears to contradict this assumption, because consumer prices are not very responsive to exchange rates. If there is no effect of exchange rates on prices that are paid by demanders of goods, then the exchange rate does not play the role in adjusting relative prices that Friedman posits. The jury is still out on whether we can reconcile the evidence of low exchange rate pass-through to consumer prices with a significant expenditure-switching effect.

Even for advanced countries that have credible monetary policies and stable financial markets, the expenditure-switching issue is only one of several factors that are important in the choice of fixed versus floating. As has been noted, one traditional argument in favor of floating exchange rates is that countries are able to follow independent monetary policies that allow monetary policy to react to local conditions. In the model of Devereux and Engel (2001), independent monetary policies are strictly suboptimal - they lead to undesirable deviations from the law of one price, and do not yield any gains. But the structure of their model rules out possible gains from monetary policy, because it assumes a full 
set of nominal state-contingent claims, identical preferences for home and foreign households, and that all goods are traded.

On the other hand, there is evidence that fixed exchange rates, or currency unions, confer gains that are not addressed in the models discussed here. Rose (2000) and Frankel and Rose (2001) find empirical evidence that joining currency unions will increase the volume of trade between union members, and the increased trade will stimulate growth. These papers do not explain why currency unions increase trade, but presumably the unions somehow foster more tightly integrated markets. Indeed, Parsley and Wei (2001b), Rogers (2001), and Goldberg and Verboven (2001b), find that deviations from the law of one price are small for currency union members - even smaller than for countries that have fixed exchange rates but separate currencies. So, the choice of exchange rate regime, and particularly the choice to join a currency union, might influence how prices are set.

The models discussed here assume that the exchange rate is driven by monetary and real factors, and there is no significant role for speculative bubbles. If bubbles are important in determining exchange rates, then perhaps a stronger case for fixed exchange rates or currency union can be made. Jeanne and Rose (2001) advance the view that fixed exchange rates are desirable on the grounds that they help reduce the role of pure noise in exchange rates.

Missing from my survey of empirical work has been evidence concerning quantities: trade flows or employment, for example. Integrating this evidence is important, but beyond the scope of this paper. Microeconomic studies that examine how imports of particular types of goods, or how employment in specific industries, are affected by changes in import prices must be applied with a dollop of caution. That is because there is a missing link that must be supplied before one can use these studies to judge the quantitative significance of the expenditure-switching effect: the degree of pass-through. Import demand may be fairly elastic with respect to price changes, but if the import price is inelastic with respect to the nominal exchange rate the overall effect on import demand may be small.

Aggregate studies that link employment or aggregate imports or sectoral employment to real exchange rates suffer less from this problem, because we know that for advanced countries the real 
exchange rate moves closely with the nominal exchange rate. Hooper, Johnson, and Marquez (2000) estimate short-run aggregate import and export elasticities for the G-7 countries. The find these elasticities are uniformly small, and generally statistically insignificant from zero. They conclude, "The evidence suggests that... changes in relative prices play a lesser role as a short-run international conduit."

On the other hand, studies of the effects of real exchange rates on employment, such as Gourinchas (1998, 1999), and Goldberg and Tracy (2000), do find statistically significant effects. It is difficult to judge, however, the economic significance of their findings for the importance of the expenditure-switching effect without placing them in the context of a general equilibrium model. For example, Gourinchas (1998) finds "an average $0.27 \%$ contraction in tradable employment over the 3 quarters following a mild $10 \%$ appreciation of the real exchange rate." Gourinchas (1999) finds "a 1 percent appreciation of the real exchange rate destroys 0.95 percent of tradable jobs over the next two years." It is difficult to judge whether such changes imply that nominal exchange rate flexibility has large or small effects on welfare unless these findings can be integrated into a full general equilibrium model.

The new open economy macroeconomics has given us a structured way to think about the issues that are important when considering the desirability of floating exchange rates versus currency union. Unfortunately for policy makers facing a near-term deadline for choosing an exchange-rate system, our knowledge has not advanced far enough to offer a firm recommendation backed up by appropriate theory. 


\section{References}

Bacchetta, Philippe, and Eric van Wincoop, 2000, "Does Exchange Rate Stability Increase Trade and Welfare?” American Economic Review 90, 1093-1109.

Betts, Caroline, and Michael B. Devereux, 1996, "The Exchange Rate in a Model of Pricing-to-Market," European Economic Review 40, 1007-1021.

Betts, Caroline, and Michael B. Devereux, 2000, "Exchange Rate Dynamics in a Model of Pricing-toMarket," Journal of International Economics 50, 215-244.

Betts, Caroline, and Timothy J. Kehoe, "Real Exchange Rate Movements and the Relative Price of Nontraded Goods," University of Minnesota, mimeo.

Buiter, Willem, 1999, "The EMU and the NAMU: What is the Case for North American Monetary Union?" Canadian Public Policy 25, 285-305.

Burstein, Ariel; Joao C. Neves; and, Sergio Rebelo, 2000, "Distribution Costs and Exchange Rate Dynamics during Exchange-Rate-Based Stabilizations," National Bureau of Economic Research, working paper no. 7862 .

Burstein, Ariel; Martin Eichenbaum; and, Sergio Rebelo, 2002, “Why Are Rates of Inflation So Low after Large Devaluations?” National Bureau of Economic Research, working paper no. 8748.

Chari, V.V.; Patrick J. Kehoe; and, Ellen R. McGrattan, 2000, "Can Sticky Price Models Generate Volatile and Persistent Exchange Rates?" National Bureau of Economics Research Working Paper, no. 7869.

Corsetti, Giancarlo, and Paolo Pesenti, 2001, "International Dimensions of Optimal Monetary Policy," University of Rome III, manuscript.

Crucini, Mario J.; Chris I. Telmer; and, Marios Zachariadis, 2001, "Understanding European Real Exchange Rates," Vanderbilt University, mimeo.

Devereux, Michael B., and Charles Engel, 1998, "Fixed vs. Floating Exchange Rates: How Price Setting Affects the Optimal Choice of Exchange-Rate Regime," National Bureau of Economic Research Working Paper, no. 6867.

Devereux, Michael B., and Charles Engel, 2001, "Monetary Policy in the Open Economy Revisited: Exchange Rate Flexibility and Price Setting Behavior," University of Wisconsin - Madison, manuscript.

Devereux, Michael B., and Charles Engel, 2002, "Exchange Rate Pass-Through, Exchange Rate Volatility, and Exchange Rate Disconnect,” Journal of Monetary Economics, forthcoming.

Devereux, Michael B.; Charles Engel; and Cédric Tille, 1999, "Exchange Rate Pass-Through and the Welfare Effects of the Euro," National Bureau of Economic Research Working Paper, no. 7382. 
Engel, Charles, 1993, "Real Exchange Rates and Relative Prices: An Empirical Investigation,” Journal of Monetary Economics 32, 35-50.

Engel, Charles, 1999, "Accounting for U.S. Real Exchange Rate Changes," Journal of Political Economy 107, 507-538.

Engel, Charles, 2002, "Expenditure Switching and Exchange Rate Policy,” National Bureau of Economic Research, working paper no. \#\#\#\#.

Engel, Charles, and John H. Rogers, 1996, "How Wide is the Border?" (with John Rogers), American Economic Review 86, 1112-1125.

Engel, Charles, and John H. Rogers, 2001, "Deviations From the Purchasing Power Parity: Causes and Welfare Costs,” Journal of International Economics 55, 29-57.

Frankel, Jeffrey A., and Andrew K. Rose, 2001, “An Estimate of the Effect of Currency Unions on Trade and Growth," Quarterly Journal of Economics, forthcoming.

Friedman, Milton, 1953, "The Case for Flexible Exchange Rates," in Essays in Positive Economics (Chicago: University of Chicago Press), 157-203.

Goldberg, Linda, and José Campa, 2001, “Exchange Rate Pass-Through into Import Prices: A Macro or Micro Phenomenon?" Federal Reserve Bank of New York, mimeo.

Goldberg, Linda, and Joseph Tracy, 2000, "Exchange Rates and Local Labor Markets," in Robert Feenstra, ed., Trade and Wages (NBER and Chicago).

Goldberg, Penelopi Koujianou, and Michael M. Knetter, 1997, "Goods Prices and Exchange Rates: What Have We Learned?” Journal of Economic Literature 35, 1243-1272.

Goldberg, Penelopi Koujianou, and Frank Verboven, 2001a, "The Evolution of Price Dispersion in the European Car Market,” Review of Economic Studies 68, 811-848.

Goldberg, Penelopi Koujianou, and Frank Verboven, 2001b, "Market Integration and Convergence to the Law of One Price: Evidence from the European Car Market," National Bureau of Economic Research, working paper no. 8402.

Gourinchas, Pierre-Olivier, 1998, "Exchange Rates and Jobs: What Do We Learn from Job Flows?" NBER Macroeconomics Annual, 1998, 153-208.

Gourinchas, Pierre-Olivier, 1999, "Exchange Rates Do Matter: French Job Reallocation and Exchange Rate Turbulence, 1984-1992,” European Economic Review 43, 1279-1316.

Hooper, Peter; Karen Johnson; and, Jaime Marquez, 2000, “Trade Elasticities for the G-7 Countries," Princeton Studies in International Economics, no. 87.

Isard, Peter, 1977, "How Far Can We Push the Law of One Price?" American Economic Review 67, 942-948. 
Jeanne, Olivier, and Andrew K. Rose, 2001, “Noise and Exchange Rate Regimes,” Quarterly Journal of Economics, forthcoming.

Kravis, Irving B., and Robert E. Lipsey, 1978, "Price Behavior in Light of Balance of Payments Theories," Journal of International Economics 12, 201-223.

Krugman, Paul, 1989, Exchange Rate Instability (Cambridge: MIT Press).

Lane, Philip R., 2001, “The New Open Economy Macroeconomics: A Survey,” Journal of International Economics 54, 235-266.

McCallum, Bennett T., and Edward Nelson, 2000, "Monetary Policy for an Open Economy: An Alternative Framework with Optimizing Agents and Sticky Prices," Oxford Review of Economic Policy 16, 74-91.

Mundell, Robert, 1968, International Economics (New York: MacMillan).

Mussa, Michael, 1986, "Nominal Exchange Rate Regimes and the Behavior of Real Exchange Rates: Evidence and Implications," Carnegie-Rochester Conference Series on Public Policy 25, 117213.

Obstfeld, Maurice, 2001, "International Macroeconomics: Beyond the Mundell-Fleming Model," IMF Staff Papers 47 (Special Issue), 1-39.

Obstfeld, Maurice, and Kenneth Rogoff, 1995, "Exchange Rate Dynamics Redux," Journal of Political Economy 103, 624-660.

Obstfeld, Maurice, and Kenneth Rogoff, 1998, "Risk and Exchange Rates," National Bureau of Economics Research Working Paper, no. 6694.

Obstfeld, Maurice, and Kenneth Rogoff, 2000a, "New Directions for Stochastic Open Economy Models," Journal of International Economics 50, 117-153.

Obstfeld, Maurice, and Kenneth Rogoff, 2000b, "The Six Major Puzzles in International Macroeconomics: Is There a Common Cause?” NBER Macroeconomics Annual 2000, 339-390.

Obstfeld, Maurice, and Kenneth Rogoff, 2001, "Global Implications of Self-Oriented National Monetary Rules," Department of Economics, University of California, Berkeley, manuscript.

Obstfeld, Maurice, and Alan M. Taylor, 1997, "Non-linear Aspects of Goods Market Arbitrage and Adjustment: Heckscher's Commodity Points Revisited," Journal of the Japanese and International Economies 11, 441-479.

Parsley, David C., and Shang-Jin Wei, 2001a, "Explaining the Border Effect: The Role of Exchange Rate Variability, Shipping Costs and Geography,” Journal of International Economics 55, 87-105.

Parsley, David C., and Shang-Jin Wei, 2001b, "Limiting Currency Volatility to Stimulate Goods Market Integration: A Price Based Approach," Owens Graduate School of Management, Vanderbilt University, manuscript. 
Rogers, John H., 2001, "Price Level Convergence, Relative Prices, and Inflation in Europe," Board of Governors of the Federal Reserve System, International Finance Discussion Paper, no. 699.

Rogers, John H., and Michael Jenkins, 1996, "Haircuts or Hysteresis? Sources of Movements in Real Exchange Rates,” Journal of International Economics 38, 339-360.

Rogoff, Kenneth, 1996, “The Purchasing Power Parity Puzzle,” Journal of Economic Literature 34, 647668.

Rose, Andrew K., 2000, “One Money, One Market: The Effect of Common Currencies on Trade," Economic Policy 15, 7-46.

Tille, Cédric, 2000, " 'Beggar-Thy-Neighbor' or 'Beggar-Thyself'? The Income Effect of Exchange Rate Fluctuations", Federal Reserve Bank of New York, Staff Report 112. 


\section{Table 1}

\section{Regressions of Relative Price Volatility on Distance or Trade Volumes}

\section{One-Month Differences}

\begin{tabular}{|c|c|c|c|c|c|c|c|c|}
\hline & \# & $\begin{array}{c}\text { Estimation } \\
\text { Method }\end{array}$ & $\begin{array}{c}\text { Log of } \\
\text { Distance }\end{array}$ & $\begin{array}{c}\text { Log of } \\
\text { Volume } \\
\text { of } \\
\text { Bilateral } \\
\text { Trade }\end{array}$ & Constant & JADUM & ATLDUM & $\begin{array}{c}\mathrm{R}- \\
\text { Squared }\end{array}$ \\
\hline \multirow{3}{*}{$\begin{array}{c}\text { Standard } \\
\text { Deviation of } \\
\text { Relative Price } \\
\text { of Food }\end{array}$} & 1 & OLS & $\begin{array}{c}0.41 \\
(5.32)\end{array}$ & & $\begin{array}{c}-0.87 \\
(-1.78) \\
\end{array}$ & $\begin{array}{c}0.58 \\
(2.85)\end{array}$ & $\begin{array}{c}0.34 \\
(2.04)\end{array}$ & 0.89 \\
\hline & 2 & OLS & & $\begin{array}{c}-0.17 \\
(-3.48) \\
\end{array}$ & $\begin{array}{c}-2.04 \\
(-1.88) \\
\end{array}$ & $\begin{array}{c}1.17 \\
(7.88)\end{array}$ & $\begin{array}{c}0.76 \\
(5.65) \\
\end{array}$ & 0.85 \\
\hline & 3 & IV & & $\begin{array}{c}-0.09 \\
(-2.94)\end{array}$ & $\begin{array}{c}3.18 \\
(6.37)\end{array}$ & $\begin{array}{c}1.56 \\
(14.69)\end{array}$ & $\begin{array}{c}1.09 \\
(11.99)\end{array}$ & 0.84 \\
\hline \multirow{3}{*}{$\begin{array}{c}\text { Standard } \\
\text { Deviation of } \\
\text { Relative Price } \\
\text { of Non-Food } \\
\text { Commodities }\end{array}$} & 4 & OLS & $\begin{array}{c}0.37 \\
(4.57)\end{array}$ & & $\begin{array}{l}-0.42 \\
(-0.82)\end{array}$ & $\begin{array}{c}0.25 \\
(1.18)\end{array}$ & $\begin{array}{c}0.27 \\
(1.58)\end{array}$ & 0.82 \\
\hline & 5 & OLS & & $\begin{array}{c}-0.13 \\
(-2.71)\end{array}$ & $\begin{array}{c}-1.12 \\
(-1.00)\end{array}$ & $\begin{array}{c}0.81 \\
(5.30)\end{array}$ & $\begin{array}{c}0.68 \\
(4.92)\end{array}$ & 0.78 \\
\hline & 6 & IV & & $\begin{array}{l}-0.13 \\
(-4.71)\end{array}$ & $\begin{array}{c}3.98 \\
(8.94)\end{array}$ & $\begin{array}{c}1.12 \\
(11.91)\end{array}$ & $\begin{array}{c}0.92 \\
(11.44)\end{array}$ & 0.82 \\
\hline
\end{tabular}

\section{Twelve-Month Differences}

\begin{tabular}{|c|c|c|c|c|c|c|c|c|}
\hline & \# & $\begin{array}{c}\text { Estimation } \\
\text { Method }\end{array}$ & $\begin{array}{c}\text { Log of } \\
\text { Distance }\end{array}$ & $\begin{array}{l}\text { Log of } \\
\text { Volume } \\
\text { of } \\
\text { Bilateral } \\
\text { Trade }\end{array}$ & Constant & JADUM & ATLDUM & $\begin{array}{c}\text { R- } \\
\text { Squared }\end{array}$ \\
\hline \multirow{3}{*}{$\begin{array}{c}\text { Standard } \\
\text { Deviation of } \\
\text { Relative Price } \\
\text { of Food }\end{array}$} & 7 & OLS & $\begin{array}{l}0.018 \\
(4.43)\end{array}$ & & $\begin{array}{l}-0.051 \\
(-1.92)\end{array}$ & $\begin{array}{l}0.027 \\
(2.43)\end{array}$ & $\begin{array}{l}0.024 \\
(2.65)\end{array}$ & 0.87 \\
\hline & 8 & OLS & & $\begin{array}{c}-0.0098 \\
(-4.19)\end{array}$ & $\begin{array}{c}-0.16 \\
(-2.95)\end{array}$ & $\begin{array}{l}0.048 \\
(6.62)\end{array}$ & $\begin{array}{l}0.038 \\
(5.74)\end{array}$ & 0.86 \\
\hline & 9 & IV & & $\begin{array}{c}-0.0024 \\
(-1.39)\end{array}$ & $\begin{array}{c}0.10 \\
(3.84)\end{array}$ & $\begin{array}{c}0.070 \\
(12.44)\end{array}$ & $\begin{array}{c}0.058 \\
(11.98)\end{array}$ & 0.81 \\
\hline \multirow{3}{*}{$\begin{array}{c}\text { Standard } \\
\text { Deviation of } \\
\text { Relative Price } \\
\text { of Non-Food } \\
\text { Commodities }\end{array}$} & 10 & OLS & $\begin{array}{l}0.022 \\
(5.28) \\
\end{array}$ & & $\begin{array}{l}-0.069 \\
(-2.64) \\
\end{array}$ & $\begin{array}{l}0.020 \\
(1.84)\end{array}$ & $\begin{array}{l}0.025 \\
(2.86) \\
\end{array}$ & 0.88 \\
\hline & 11 & OLS & & $\begin{array}{l}-0.013 \\
(-6.25)\end{array}$ & $\begin{array}{c}-0.23 \\
(-4.82)\end{array}$ & $\begin{array}{l}0.041 \\
(6.22)\end{array}$ & $\begin{array}{l}0.038 \\
(6.35)\end{array}$ & 0.84 \\
\hline & 12 & IV & & $\begin{array}{c}-0.0029 \\
(-1.71)\end{array}$ & $\begin{array}{c}0.11 \\
(4.21)\end{array}$ & $\begin{array}{c}0.071 \\
(12.41)\end{array}$ & $\begin{array}{c}0.065 \\
(13.33)\end{array}$ & 0.83 \\
\hline
\end{tabular}

t-statistics in parentheses. All regressions use 55 country-pair observations.

(Dependent variable in regression is denoted in left-most column. Standard deviations are calculated from monthly data, 1973:12-2001:1. IV estimation uses log of distance and log of products of GDP as instruments.) 
Table2

\section{Regressions of Relative Price Volatility on Distance or Trade Volumes, and Volatility of Nominal Exchange Rates}

One-Month Differences

\begin{tabular}{|c|c|c|c|c|c|c|c|c|c|}
\hline & \# & $\begin{array}{c}\text { Est. } \\
\text { Method }\end{array}$ & $\begin{array}{c}\text { Log of } \\
\text { Distance }\end{array}$ & $\begin{array}{l}\text { Log of } \\
\text { Volume } \\
\text { of } \\
\text { Bilateral } \\
\text { Trade }\end{array}$ & $\begin{array}{c}\text { Standard } \\
\text { Deviation } \\
\text { of } \\
\text { Nominal } \\
\text { Exchange } \\
\text { Rate } \\
\end{array}$ & Constant & JADUM & ATLDUM & $\begin{array}{c}\text { R- } \\
\text { Squared }\end{array}$ \\
\hline \multirow{3}{*}{$\begin{array}{c}\text { Std. } \\
\text { Dev. of } \\
\text { Relative } \\
\text { Price of } \\
\text { Food }\end{array}$} & 13 & OLS & $\begin{array}{l}0.041 \\
(1.07)\end{array}$ & & $\begin{array}{c}0.83 \\
(16.25) \\
\end{array}$ & $\begin{array}{c}0.28 \\
(1.33) \\
\end{array}$ & $\begin{array}{c}0.33 \\
(3.90) \\
\end{array}$ & $\begin{array}{l}0.016 \\
(0.23) \\
\end{array}$ & 0.98 \\
\hline & 14 & OLS & & $\begin{array}{c}0.029 \\
(18.76) \\
\end{array}$ & $\begin{array}{c}0.89 \\
(18.76) \\
\end{array}$ & $\begin{array}{c}1.09 \\
(2.61) \\
\end{array}$ & $\begin{array}{c}0.40 \\
(5.87) \\
\end{array}$ & $\begin{array}{l}0.072 \\
(1.20) \\
\end{array}$ & 0.98 \\
\hline & 15 & IV & & $\begin{array}{l}-0.055 \\
(-6.07) \\
\end{array}$ & $\begin{array}{c}0.82 \\
(24.16) \\
\end{array}$ & $\begin{array}{c}1.42 \\
(8.85) \\
\end{array}$ & $\begin{array}{c}0.44 \\
(8.02) \\
\end{array}$ & $\begin{array}{l}0.088 \\
(1.80) \\
\end{array}$ & 0.99 \\
\hline \multirow{3}{*}{$\begin{array}{c}\text { Std. } \\
\text { Dev. of } \\
\text { Relative } \\
\text { Price of } \\
\text { Comm. }\end{array}$} & 16 & OLS & $\begin{array}{c}0.17 \\
(1.91)\end{array}$ & & $\begin{array}{c}0.44 \\
(3.80)\end{array}$ & $\begin{array}{c}0.20 \\
(0.41)\end{array}$ & $\begin{array}{c}0.11 \\
(0.59)\end{array}$ & $\begin{array}{c}0.10 \\
(0.62)\end{array}$ & 0.86 \\
\hline & 17 & OLS & & $\begin{array}{l}-0.011 \\
(-0.23)\end{array}$ & $\begin{array}{c}0.56 \\
(4.91)\end{array}$ & $\begin{array}{c}0.85 \\
(0.85)\end{array}$ & $\begin{array}{c}0.33 \\
(2.01)\end{array}$ & $\begin{array}{c}0.25 \\
(1.73)\end{array}$ & 0.84 \\
\hline & 18 & IV & & $\begin{array}{c}-0.11 \\
(-4.97)\end{array}$ & $\begin{array}{c}0.49 \\
(5.98) \\
\end{array}$ & $\begin{array}{c}2.91 \\
(7.49)\end{array}$ & $\begin{array}{c}0.45 \\
(3.39) \\
\end{array}$ & $\begin{array}{c}0.32 \\
(2.74)\end{array}$ & 0.89 \\
\hline
\end{tabular}

Twelve-Month Differences

\begin{tabular}{|c|c|c|c|c|c|c|c|c|c|}
\hline & $\#$ & $\begin{array}{l}\text { Est. } \\
\text { Method }\end{array}$ & $\begin{array}{c}\text { Log of } \\
\text { Distance }\end{array}$ & $\begin{array}{l}\text { Log of } \\
\text { Volume } \\
\text { of } \\
\text { Bilateral } \\
\text { Trade }\end{array}$ & $\begin{array}{c}\text { Standard } \\
\text { Deviation } \\
\text { of } \\
\text { Nominal } \\
\text { Exchange } \\
\text { Rate }\end{array}$ & Constant & JADUM & ATLDUM & $\begin{array}{c}\text { R- } \\
\text { Squared }\end{array}$ \\
\hline \multirow{3}{*}{$\begin{array}{c}\text { Std. } \\
\text { Dev. of } \\
\text { Relative } \\
\text { Price of } \\
\text { Food }\end{array}$} & 19 & OLS & $\begin{array}{l}0.026 \\
(1.67) \\
\end{array}$ & & $\begin{array}{c}0.86 \\
(20.62) \\
\end{array}$ & $\begin{array}{c}-0.0006 \\
(-0.71) \\
\end{array}$ & $\begin{array}{c}0.0014 \\
(0.37) \\
\end{array}$ & $\begin{array}{c}-0.0030 \\
(-0.93) \\
\end{array}$ & 0.99 \\
\hline & 20 & OLS & & $\begin{array}{c}-0.0005 \\
(-0.51) \\
\end{array}$ & $\begin{array}{c}0.88 \\
(20.40) \\
\end{array}$ & $\begin{array}{c}-0.002 \\
(-0.09) \\
\end{array}$ & $\begin{array}{r}0.0049 \\
(1.52) \\
\end{array}$ & $\begin{array}{l}-0.0005 \\
(-0.17) \\
\end{array}$ & 0.98 \\
\hline & 21 & IV & & $\begin{array}{c}-0.0005 \\
(-1.04)\end{array}$ & $\begin{array}{c}0.88 \\
(23.17)\end{array}$ & $\begin{array}{l}0.017 \\
(1.90)\end{array}$ & $\begin{array}{c}0.0058 \\
(1.78)\end{array}$ & $\begin{array}{c}0.0002 \\
(0.05)\end{array}$ & 0.98 \\
\hline \multirow{3}{*}{$\begin{array}{c}\text { Std. } \\
\text { Dev. of } \\
\text { Relative } \\
\text { Price of } \\
\text { Comm. }\end{array}$} & 22 & OLS & $\begin{array}{c}0.0083 \\
(2.98) \\
\end{array}$ & & $\begin{array}{c}0.72 \\
(9.77) \\
\end{array}$ & $\begin{array}{l}-0.031 \\
(-1.97) \\
\end{array}$ & $\begin{array}{c}-0.0014 \\
(-0.21) \\
\end{array}$ & $\begin{array}{l}0.0027 \\
(0.48) \\
\end{array}$ & 0.96 \\
\hline & 23 & OLS & & $\begin{array}{c}-0.0060 \\
(-4.09)\end{array}$ & $\begin{array}{c}0.68 \\
(9.73)\end{array}$ & $\begin{array}{c}-0.11 \\
(-3.60)\end{array}$ & $\begin{array}{c}0.0075 \\
(1.42)\end{array}$ & $\begin{array}{c}0.0082 \\
(1.74)\end{array}$ & 0.96 \\
\hline & 24 & IV & & $\begin{array}{c}-0.0012 \\
(-1.29) \\
\end{array}$ & $\begin{array}{c}0.81 \\
(11.74) \\
\end{array}$ & $\begin{array}{l}0.033 \\
(2.11) \\
\end{array}$ & $\begin{array}{l}0.012 \\
(2.01) \\
\end{array}$ & $\begin{array}{l}0.012 \\
(2.36) \\
\end{array}$ & 0.95 \\
\hline
\end{tabular}

t-statistics in parentheses. All regressions use 55 observations.

(Dependent variable in regression is denoted in left-most column. Standard deviations are calculated from monthly data, 1973:12-2001:1. IV estimation uses log of distance and log of products of GDP as instruments.) 
Table 3

\section{Analysis of Variance of Regressions from Table 2}

\section{1-month changes}

\begin{tabular}{|c|c|c|c|c|c|}
\hline Regression \# & $\begin{array}{c}\text { Variance of } \\
\text { S.D. of } \\
\text { Exchange Rate } \\
\text { Component }\end{array}$ & $\begin{array}{c}\text { Variance of } \\
\text { Distance or } \\
\text { Trade } \\
\text { Component }\end{array}$ & $\begin{array}{c}\text { Covariance of } \\
\text { Ex. Rate and } \\
\text { Trade/Distance } \\
\text { Components }\end{array}$ & $\begin{array}{c}\text { Variance of } \\
\text { Dummies }\end{array}$ & $\begin{array}{c}\text { Covariance of } \\
\text { Dummies with } \\
\text { non-Dummies }\end{array}$ \\
\hline 13 & 80.6 & 0.5 & 9.7 & 3.4 & 9.7 \\
\hline 14 & 87.8 & 0.3 & -4.5 & 4.5 & 12.0 \\
\hline 15 & 77.8 & 1.0 & 1.4 & 5.9 & 13.8 \\
\hline 16 & 46.1 & 16.4 & 25.4 & 1.2 & 10.9 \\
\hline 17 & 67.9 & 0.1 & 2.1 & 8.3 & 21.7 \\
\hline 18 & 50.6 & 7.4 & 3.0 & 14.6 & 24.4 \\
\hline
\end{tabular}

\section{2-month changes}

\begin{tabular}{|c|c|c|c|c|c|}
\hline Regression \# & $\begin{array}{c}\text { Variance of } \\
\text { S.D. of } \\
\text { Exchange Rate } \\
\text { Component }\end{array}$ & $\begin{array}{c}\text { Variance of } \\
\text { Distance or } \\
\text { Trade } \\
\text { Component }\end{array}$ & $\begin{array}{c}\text { Covariance of } \\
\text { Ex. Rate and } \\
\text { Trade/Distance } \\
\text { Components }\end{array}$ & $\begin{array}{c}\text { Variance of } \\
\text { Dummies }\end{array}$ & $\begin{array}{c}\text { Covariance of } \\
\text { Dummies with } \\
\text { non-Dummies }\end{array}$ \\
\hline 19 & 92.8 & 0.8 & 7.7 & 0.2 & -1.5 \\
\hline 20 & 95.8 & 0.0 & 1.5 & 0.3 & 2.4 \\
\hline 21 & 96.0 & 0.0 & 0.3 & 0.4 & 3.3 \\
\hline 22 & 69.0 & 8.0 & 21.5 & 0.2 & 1.3 \\
\hline 23 & 64.2 & 6.1 & 17.1 & 1.5 & 11.1 \\
\hline 24 & 81.7 & 0.2 & 0.6 & 3.1 & 14.4 \\
\hline
\end{tabular}

Cell entries are the percentage of total explained sum of squares from corresponding regressions in Table 2 that are explained by each component. 


\section{Figure 1}

\section{MSE Decomposition of Real Exchange Rate Changes}

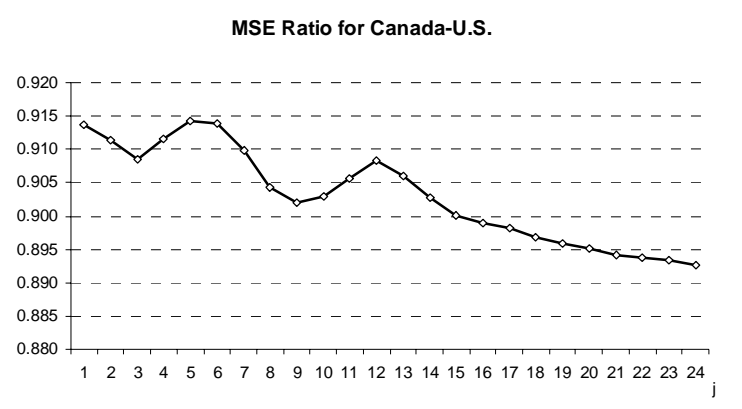

MSE Ratio for Italy-US

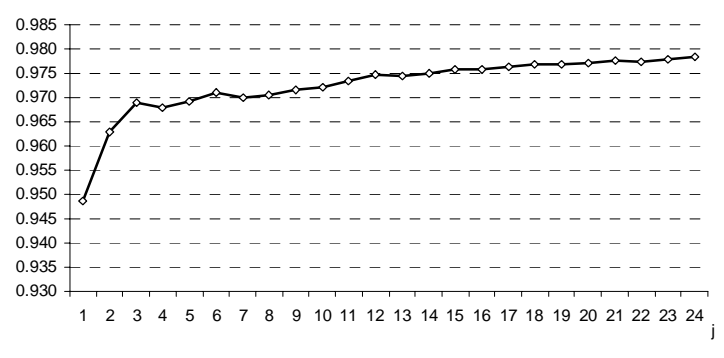

MSE Ratio for Netherlands-US

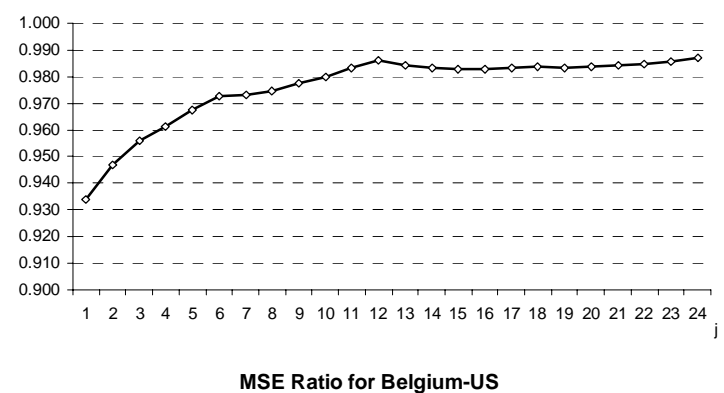

MSE Ratio for Belgium-US

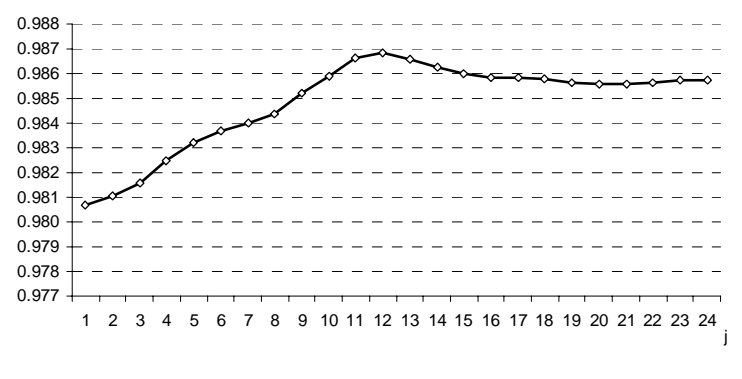

MSE Ratio for Spain-US

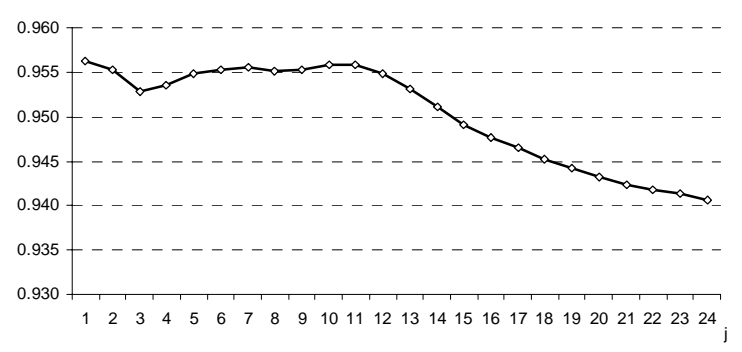

MSE Ratio for France-US

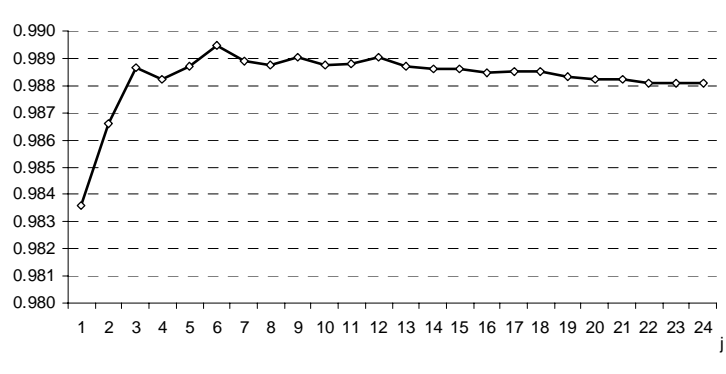

MSE Ratio for Japan-US

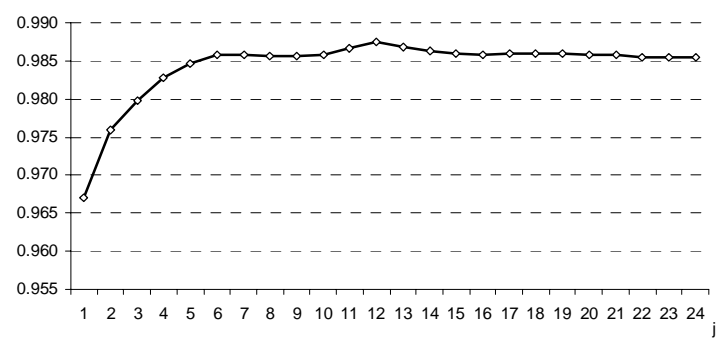

MSE Ratio for Norway-US

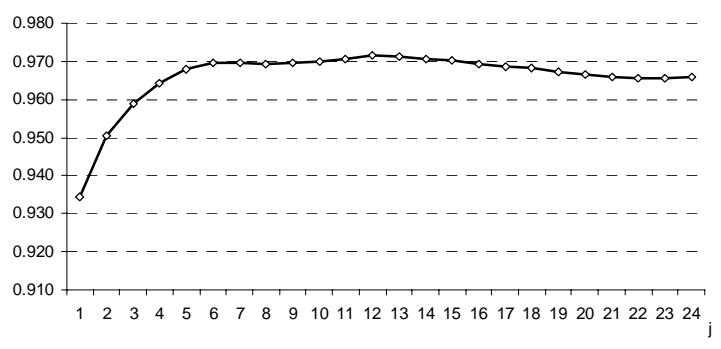

MSE Ratio for Switzerland-US

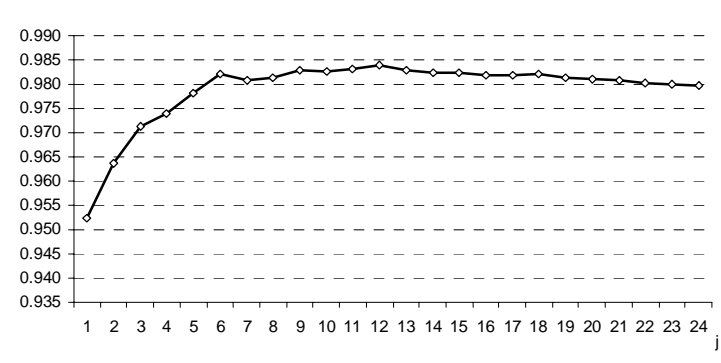

MSE Ratio for Denmark-US

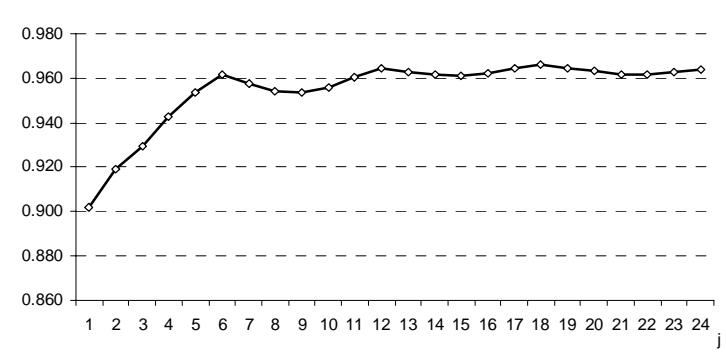




\section{Figure 1}

\section{(continued)}

MSE Ratio for Canada-Japan

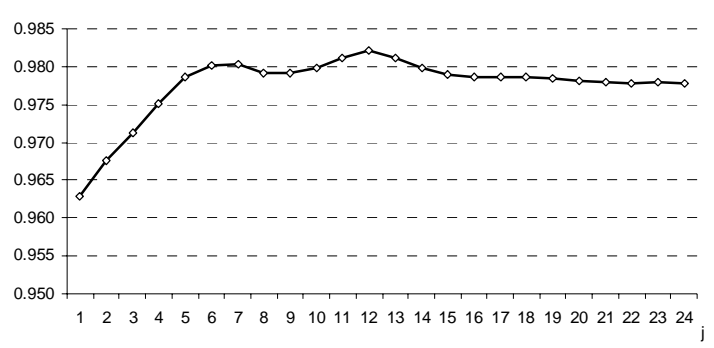

MSE Ratio for Italy-Japan

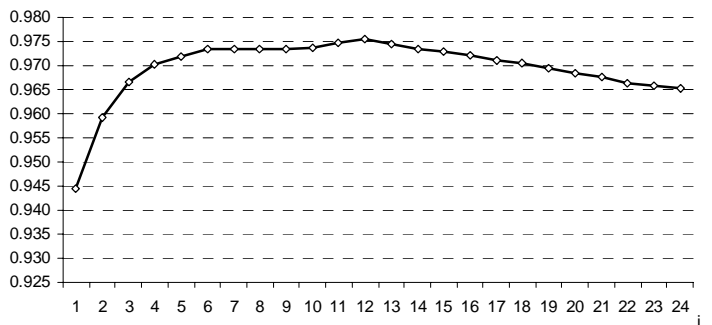

MSE Ratio for Norway-Japan

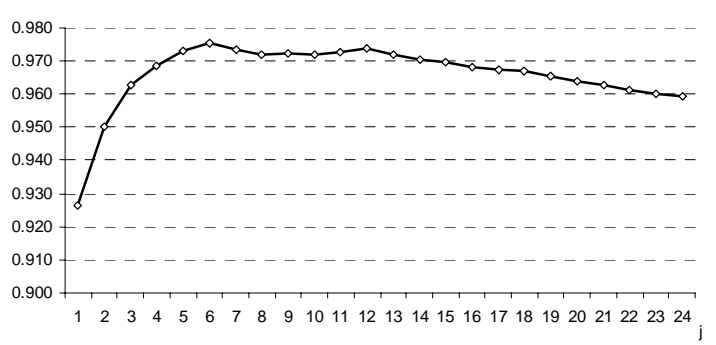

MSE Ratio for Switzerland-Japan

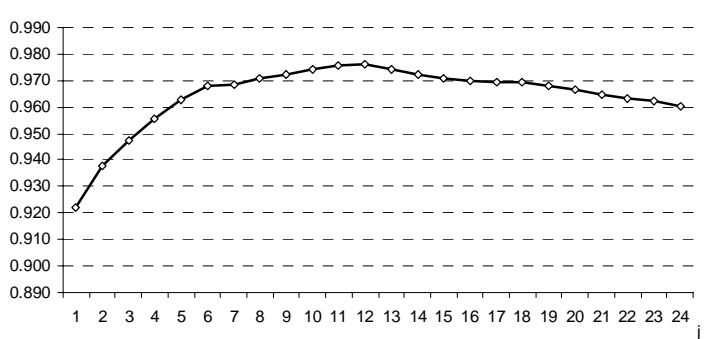

MSE Ratio for Denmark-Japan

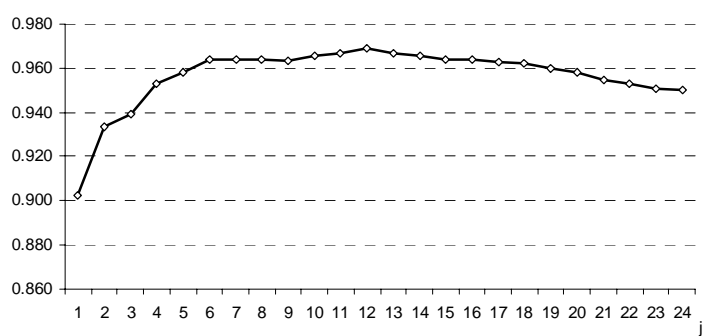

MSE Ratio for France-Japan

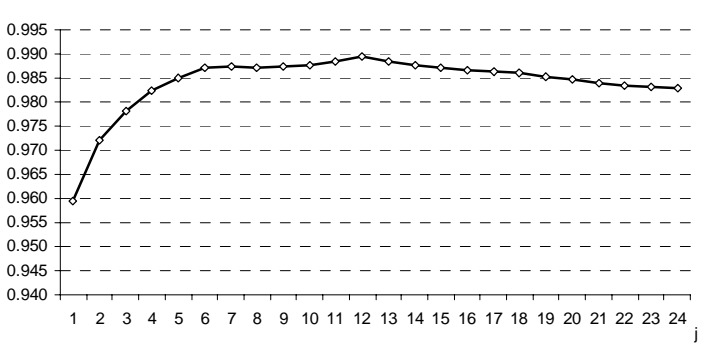

MSE Ratio for Netherlands-Japan

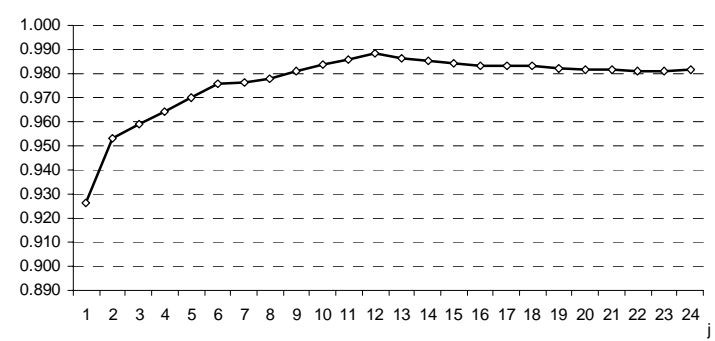

MSE Ratio for Belgium-Japan

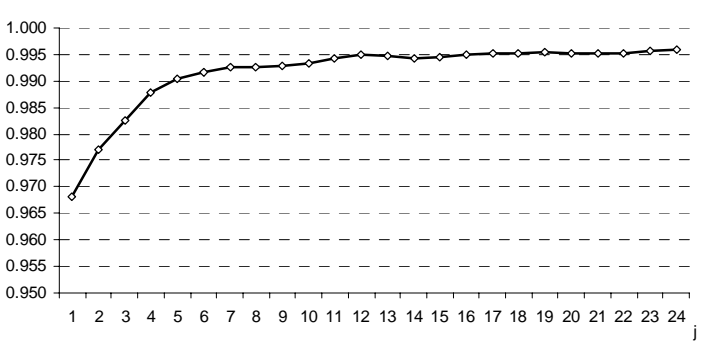

MSE Ratio for Spain-US

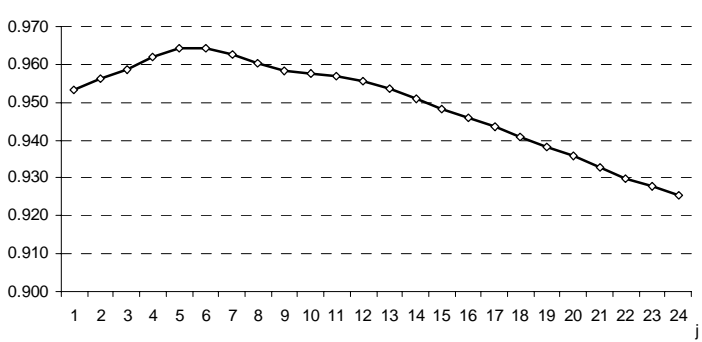

MSE Ratio for Canada-Italy

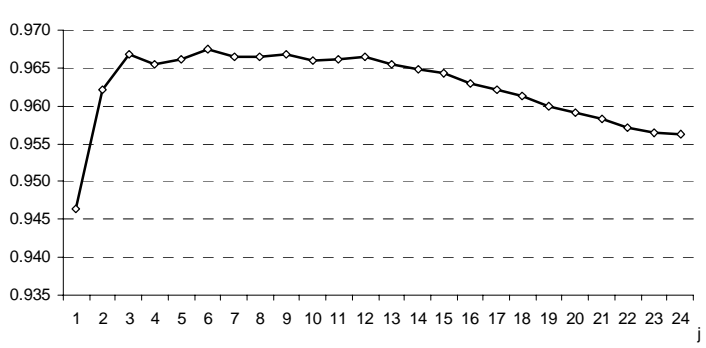




\section{Figure 1}

\section{(continued)}

MSE Ratio for France-Italy

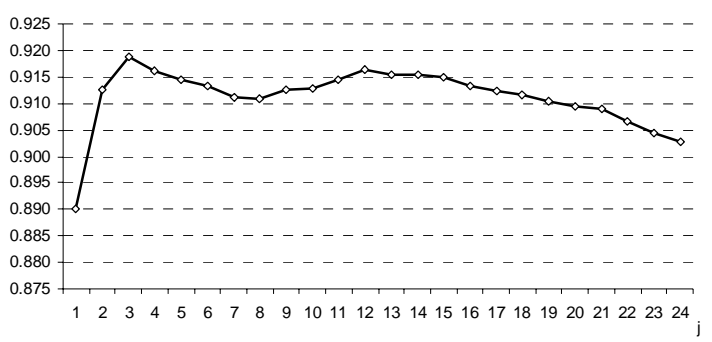

MSE Ratio for Norway-ltaly

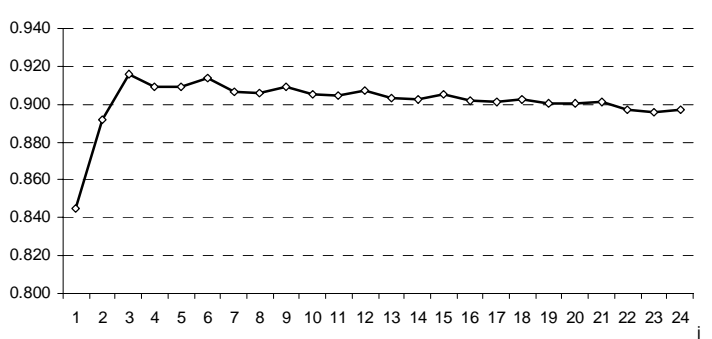

MSE Ratio for Switzerland-Italy

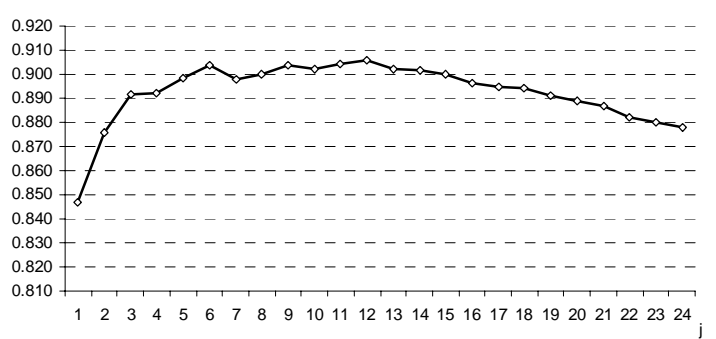

MSE Ratio for Denmark-Italy

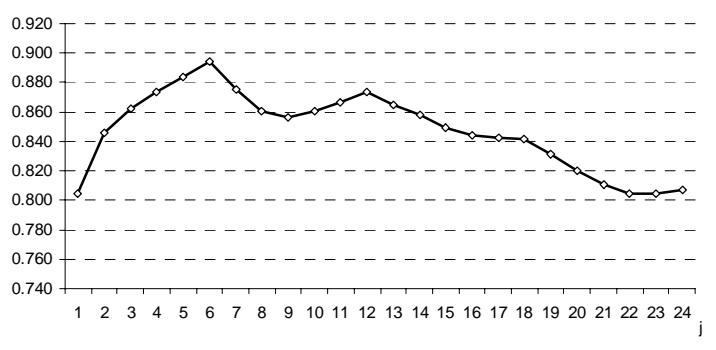

MSE Ratio for Netherlands-France

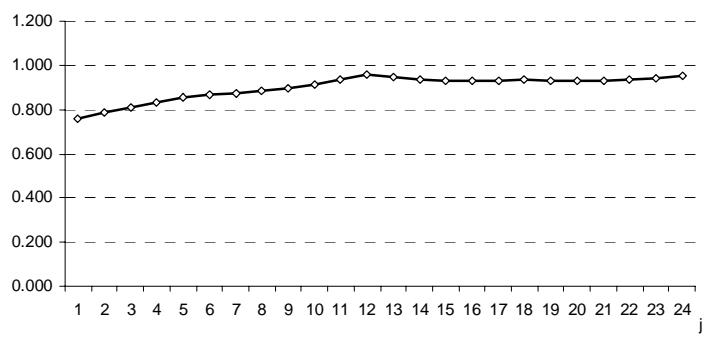

MSE Ratio for Netherlands-Italy

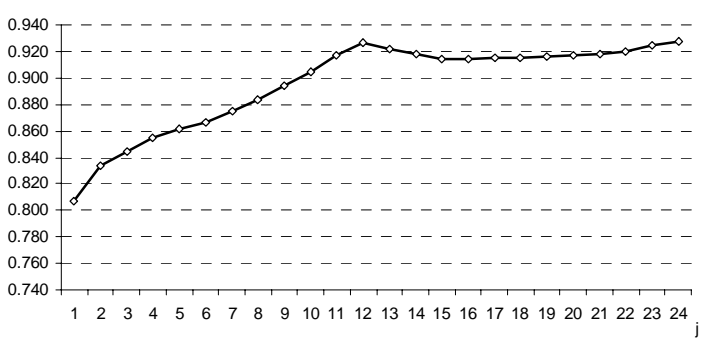

MSE Ratio for Belgium-Italy

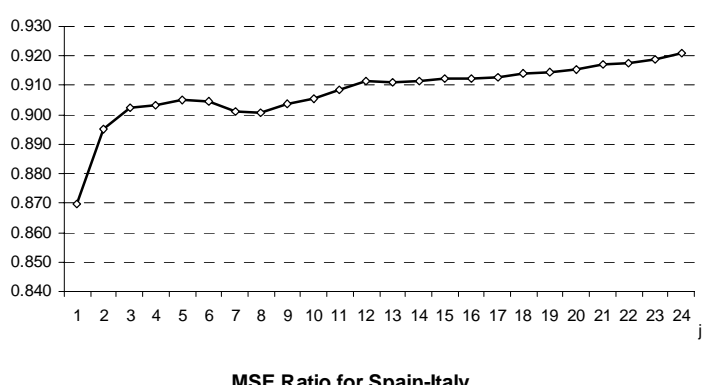

MSE Ratio for Spain-Italy

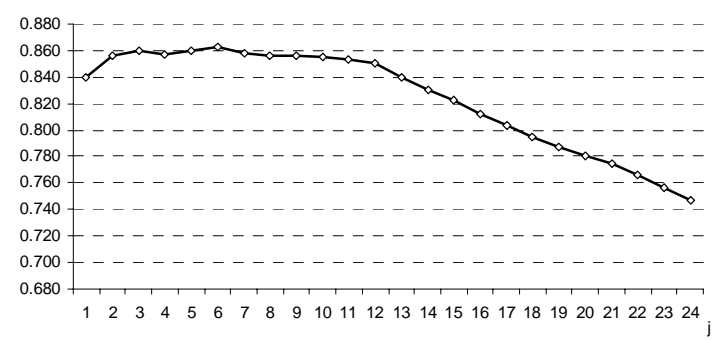

MSE Ratio for Canada-France

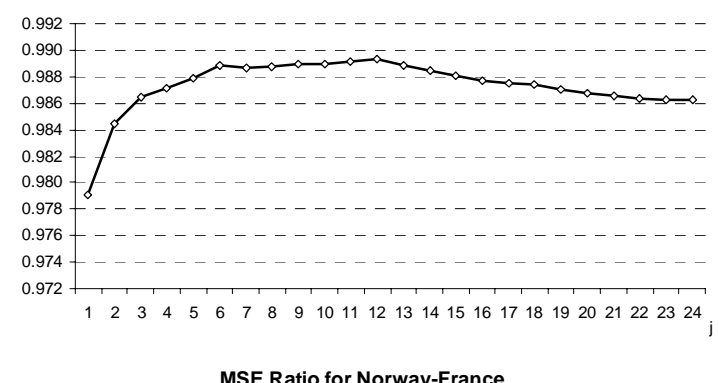

MSE Ratio for Norway-France

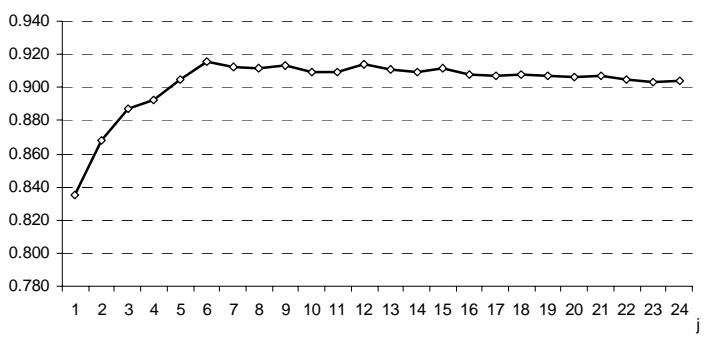




\section{Figure 1}

\section{(continued)}

MSE Ratio for Belgium-France

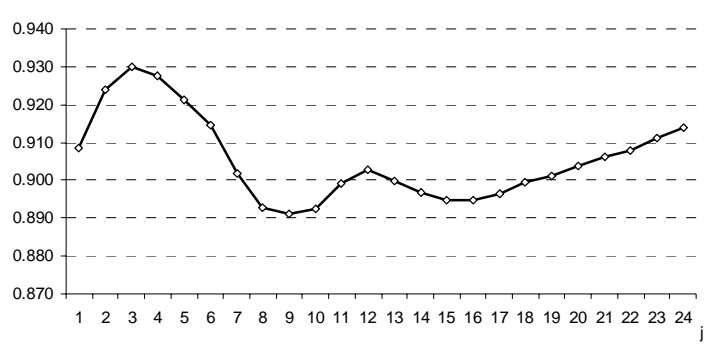

MSE Ratio for Spain-France

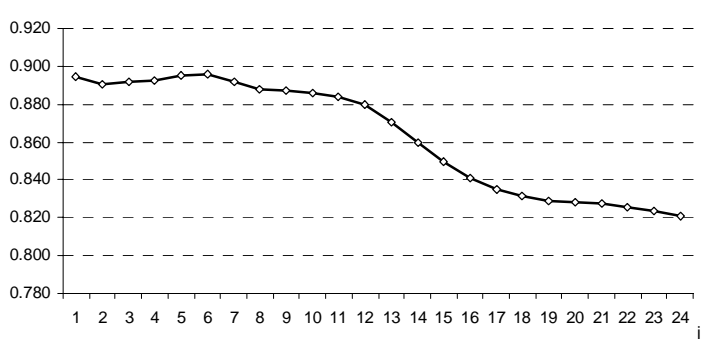

MSE Ratio for Netherlands-Canada

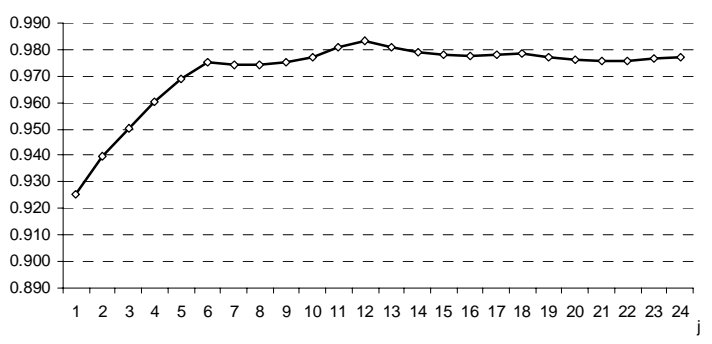

MSE Ratio for Belgium-Canada

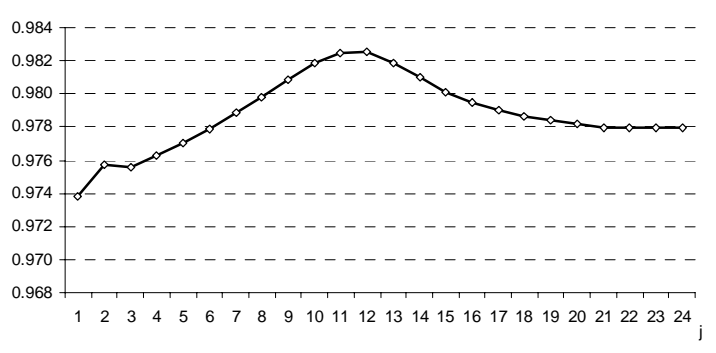

MSE Ratio for Spain-Canada

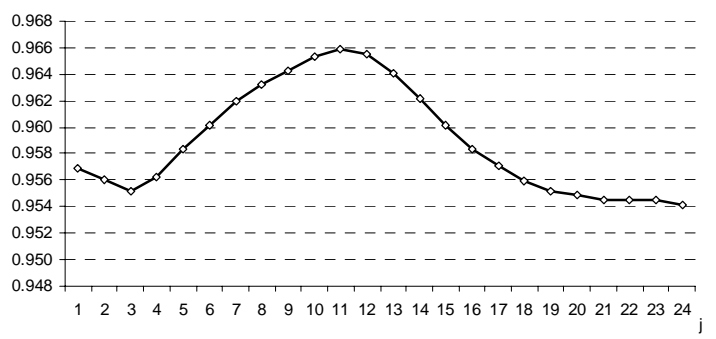

MSE Ratio for Switzerland-France

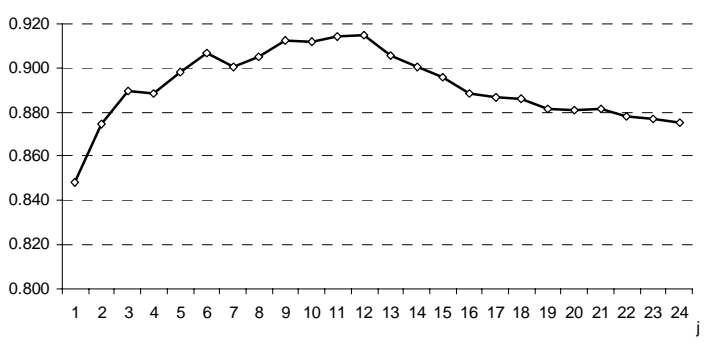

MSE Ratio for Denmark-France

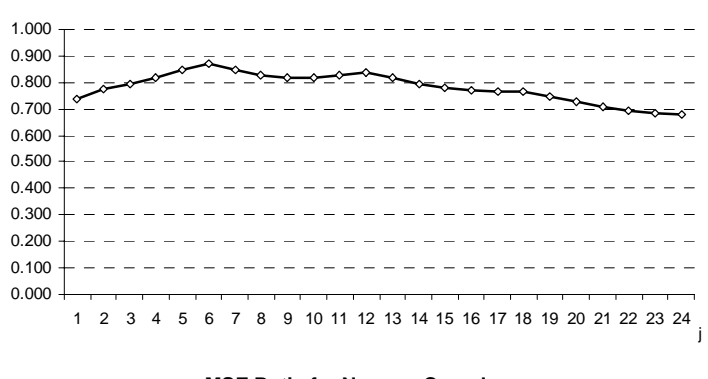

MSE Ratio for Norway-Canada

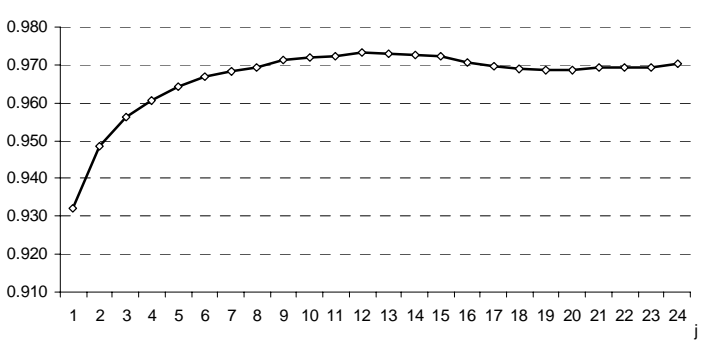

MSE Ratio for Switzerland-Canada
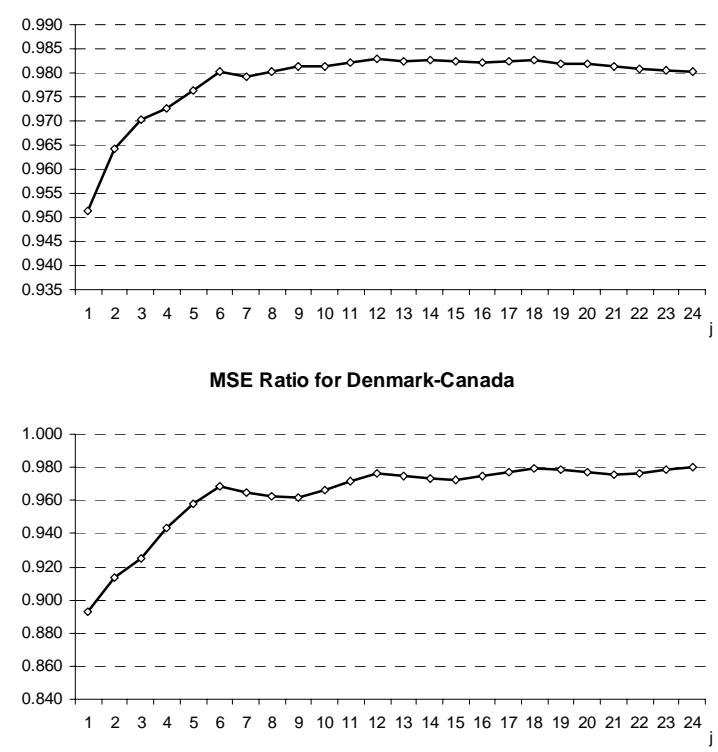


\section{Figure 1}

\section{(continued)}

MSE Ratio for Norway-Netherlands

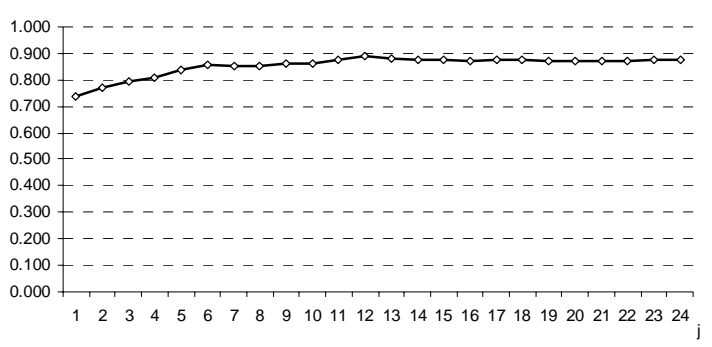

MSE Ratio for Switzerland-Netherlands

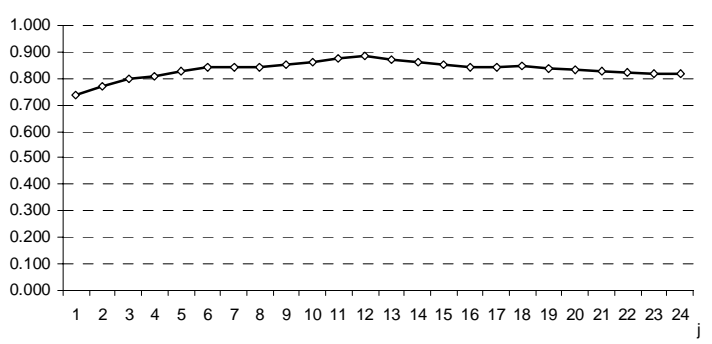

MSE Ratio for Denmark-Netherlands

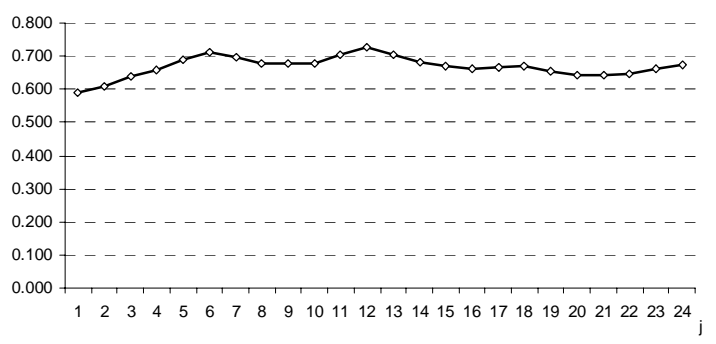

MSE Ratio for Switzerland-Norway

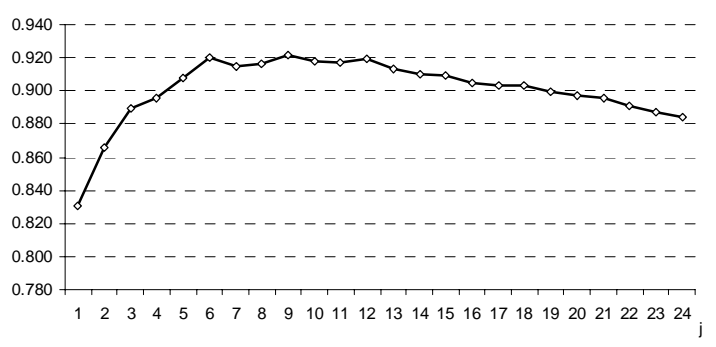

MSE Ratio for Denmark-Norway

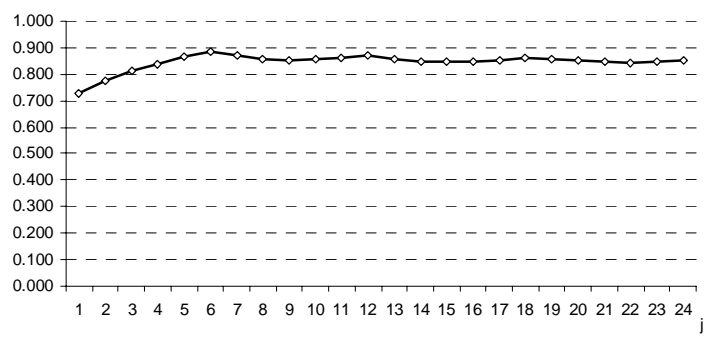

MSE Ratio for Belgium-Netherlands

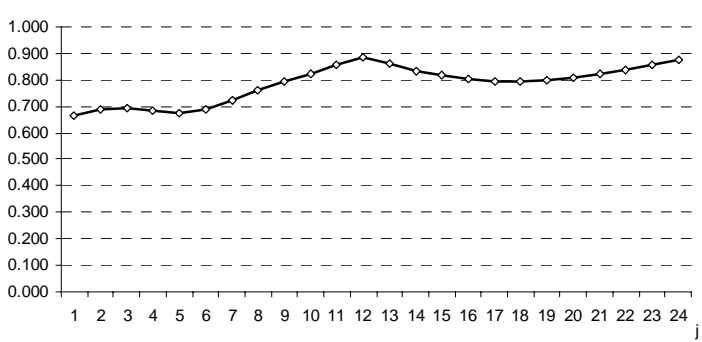

MSE Ratio for Spain-Netherlands
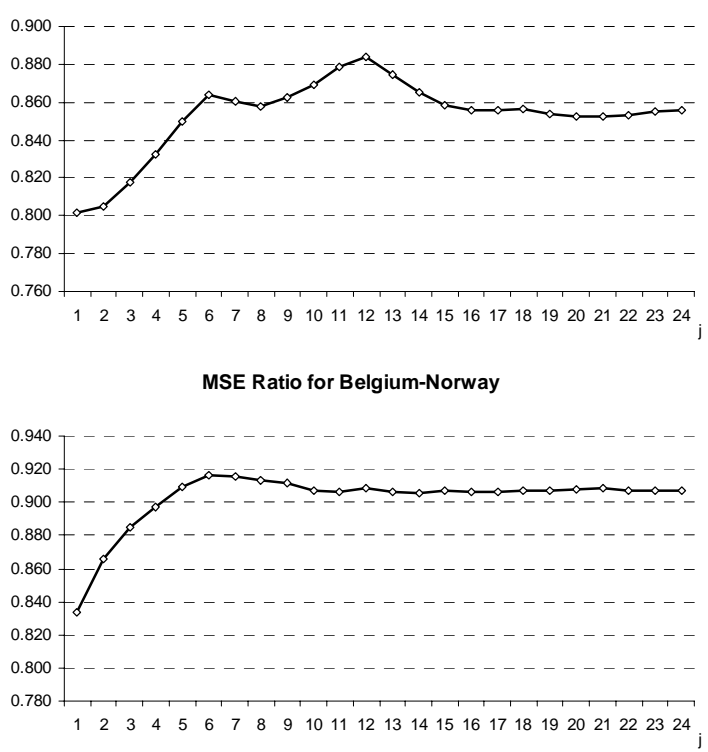

MSE Ratio for Spain-Norway

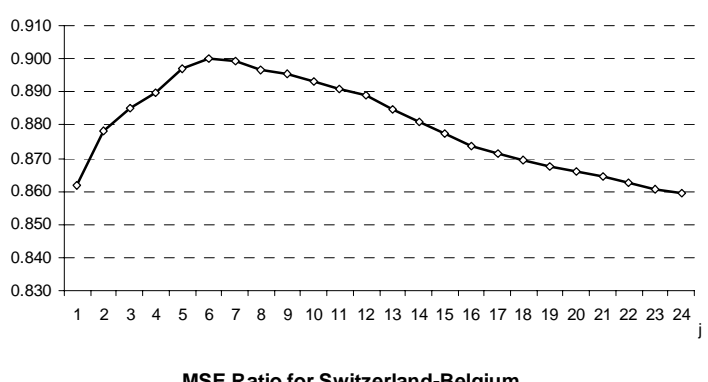

MSE Ratio for Switzerland-Belgium

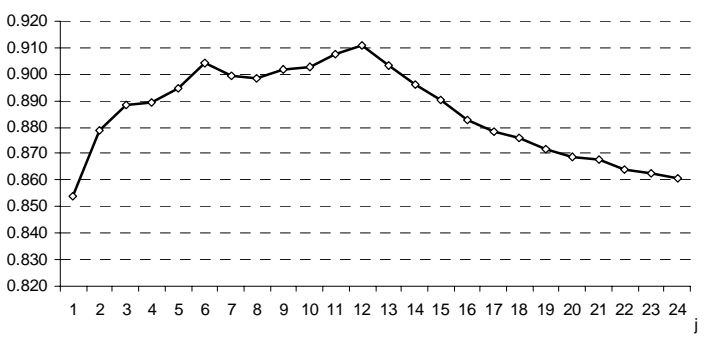




\section{Figure 1}

\section{(continued)}
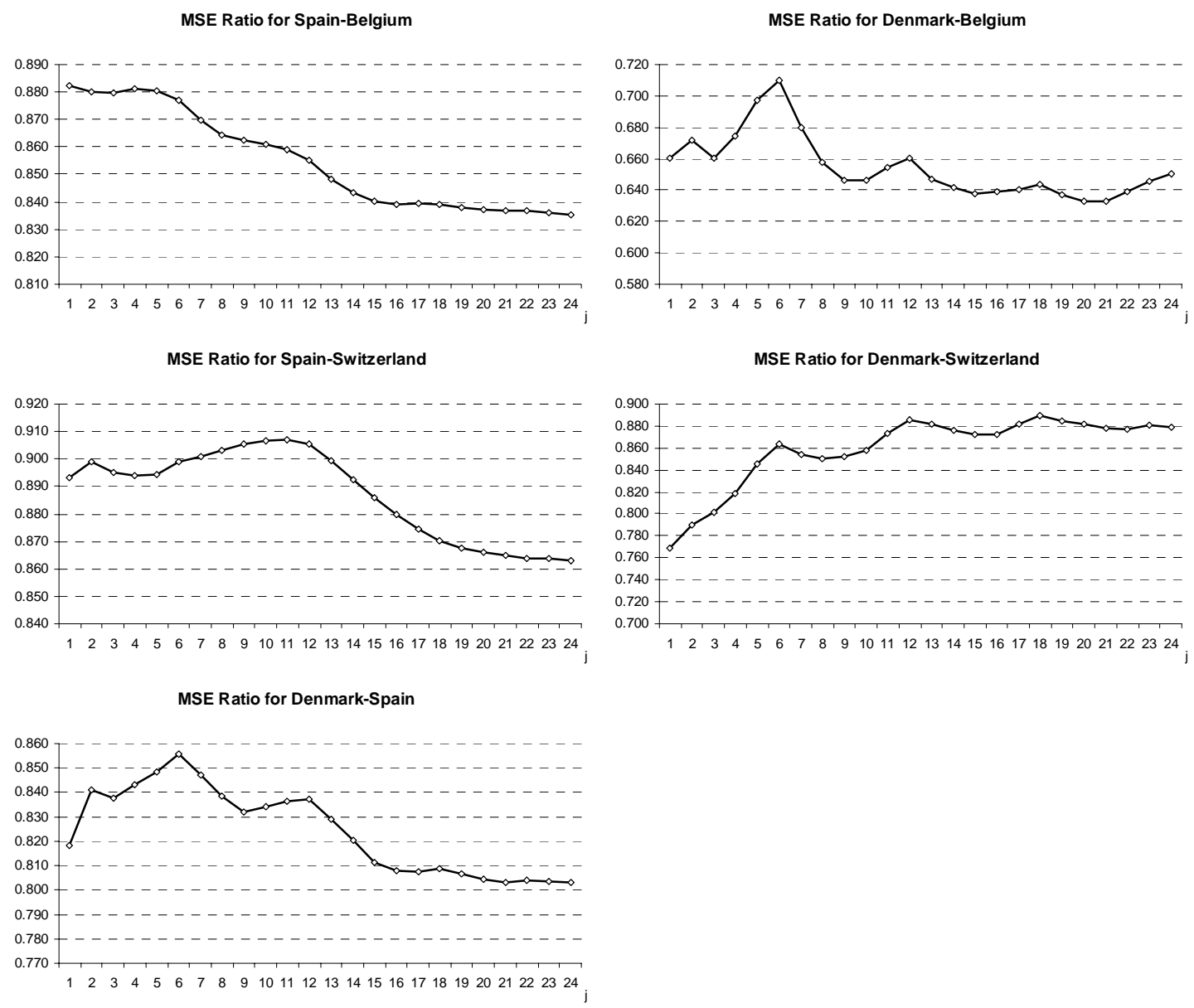

(Horizontal axis: horizon (in months.) Vertical axis: MSE share due to LOOP violations.) 


\section{Figure 2}

\section{Coefficient Estimates for Regression of Traded Prices on Service Prices}

Coefficient estimates for Canada-US

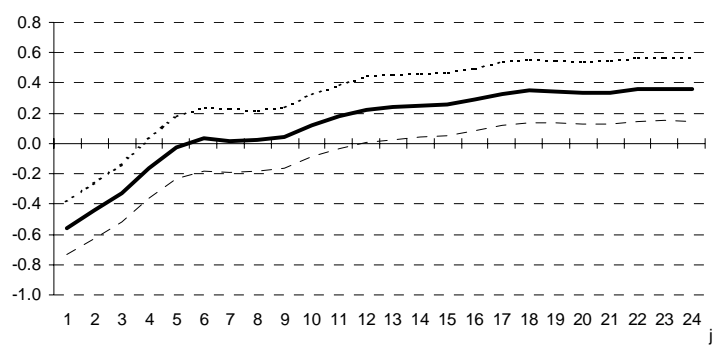

Coefficient estimates for Italy-US

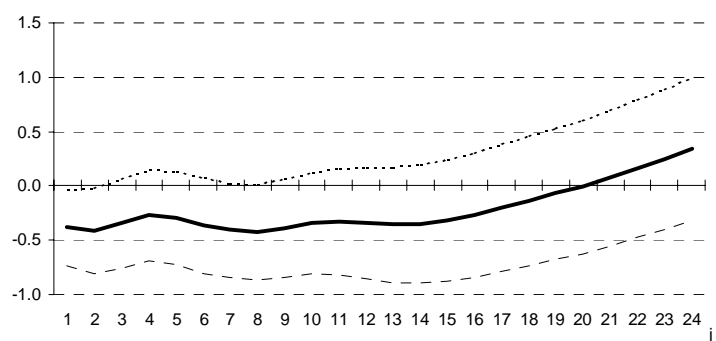

Coefficient estimates for Netherlands-US

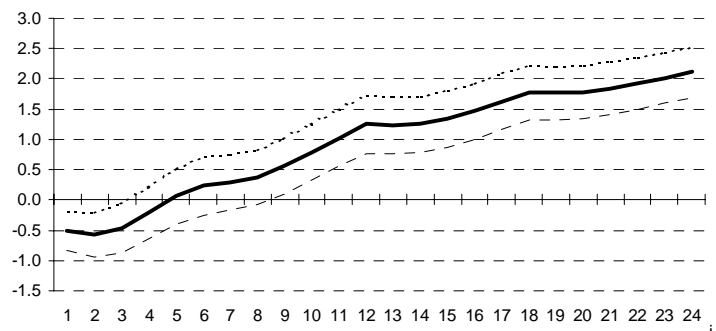

Coefficient estimates for Belgium-US

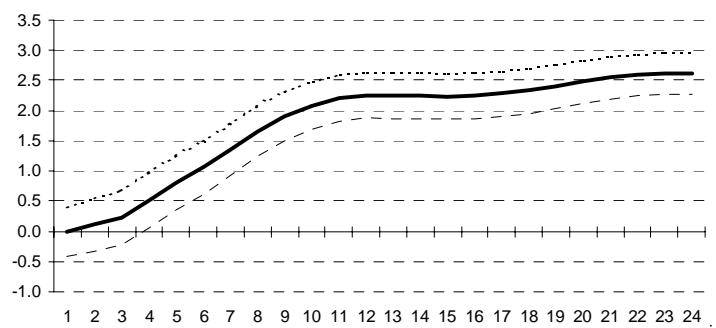

Coefficient estimates for Spain-US

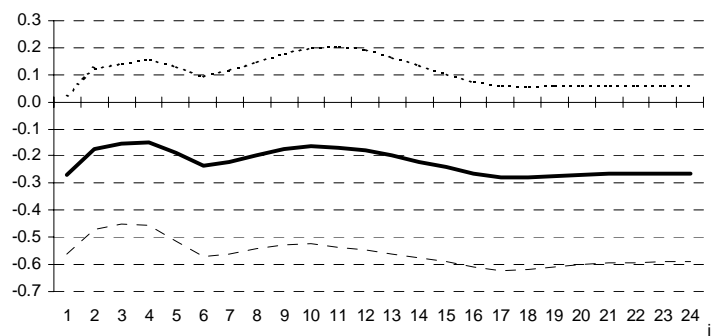

Coefficient estimates for France-US

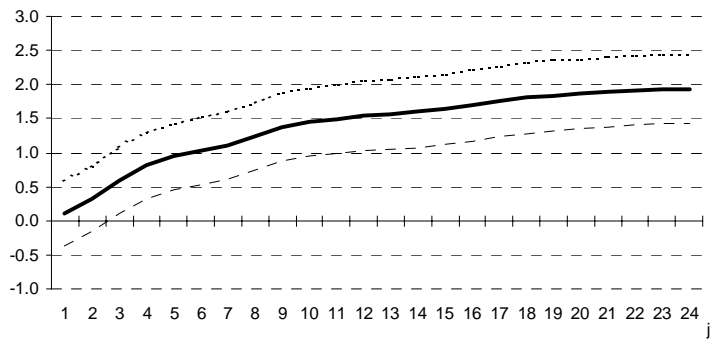

Coefficient estimates for Japan-US

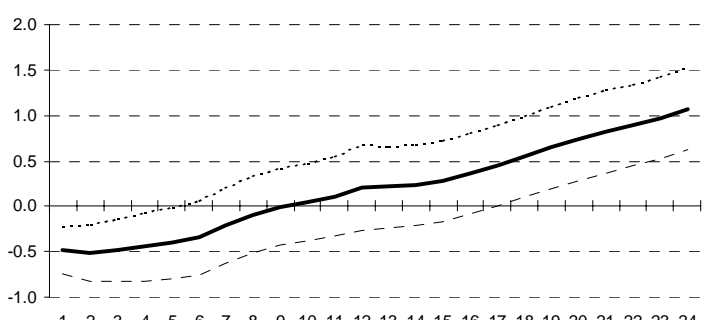

Coefficient estimates for Norway-US

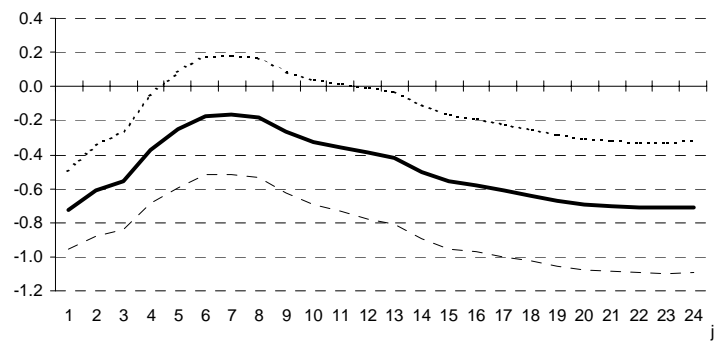

Coefficient estimates for Switzerland-US

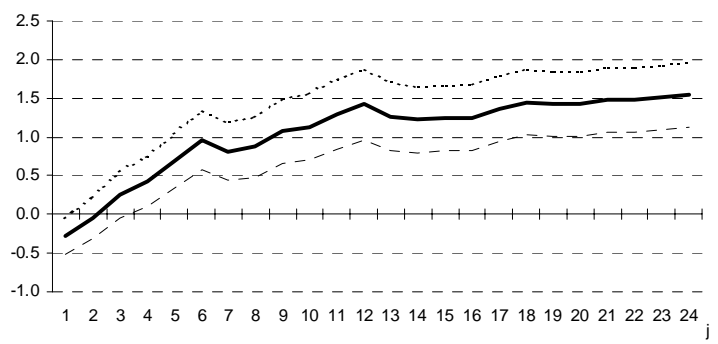

Coefficient estimates for Denmark-US

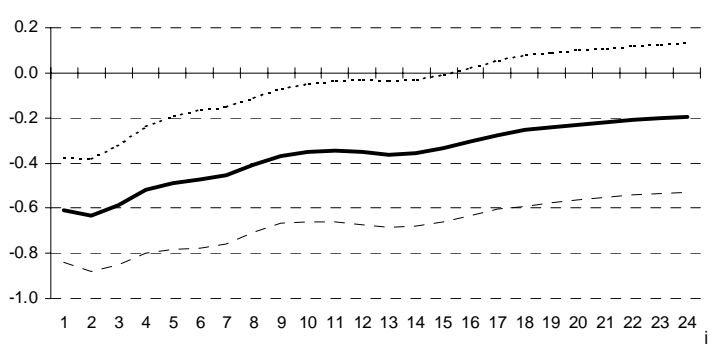




\section{Figure 2}

\section{(continued)}

Coefficient estimates for Canada-Japan

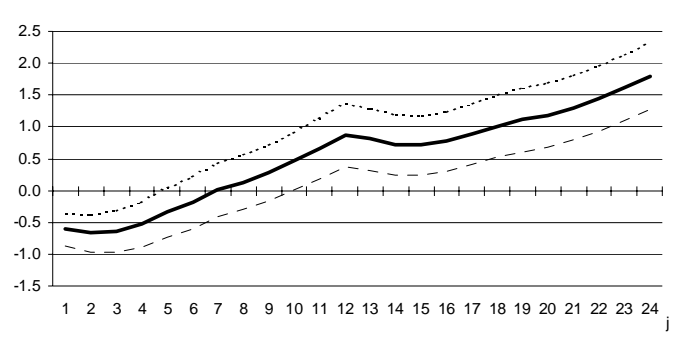

Coefficient estimates for Italy-Japan

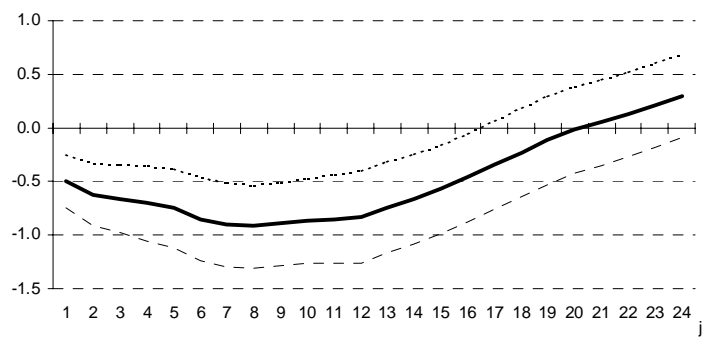

Coefficient estimates for Norway-Japan

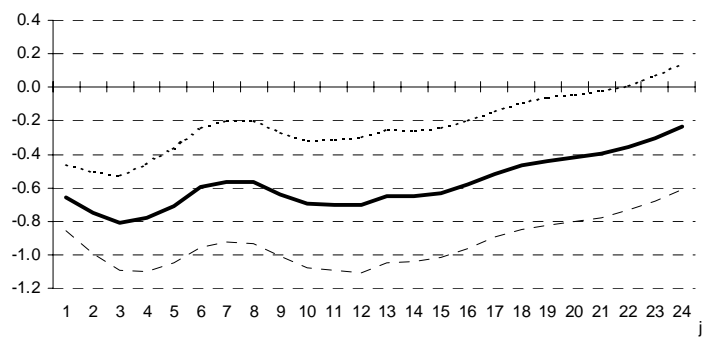

Coefficient estimates for Switzerland-Japan

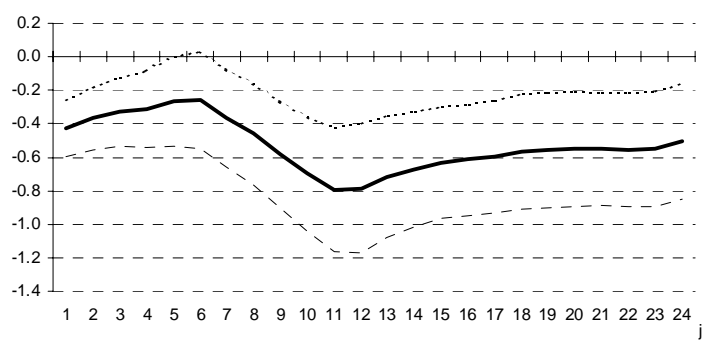

Coefficient estimates for Denmark-Japan

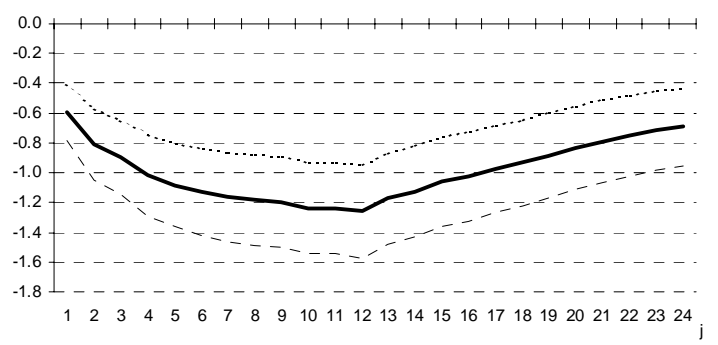

Coefficient estimates for France-Japan

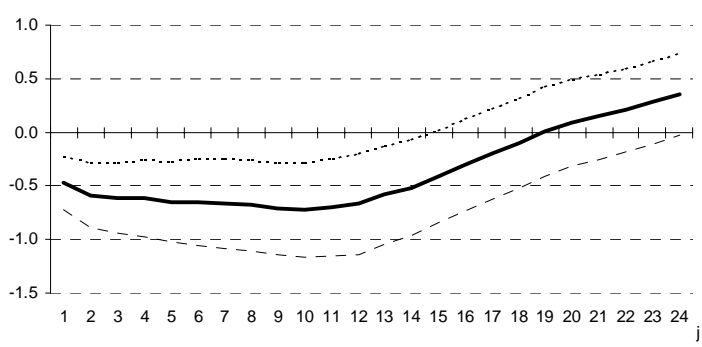

Coefficient estimates for Netherlands-Japan

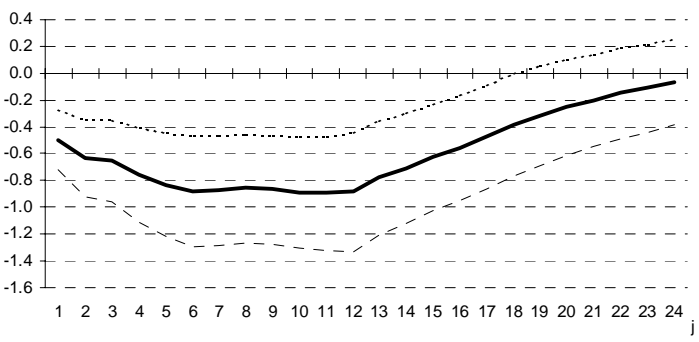

Coefficient estimates for Belgium-Japan

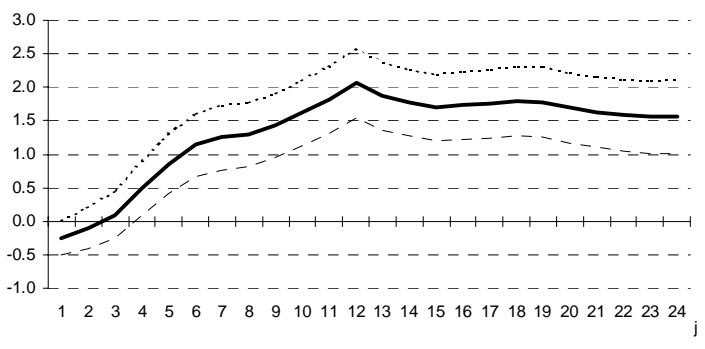

Coefficient estimates for Spain-Japan

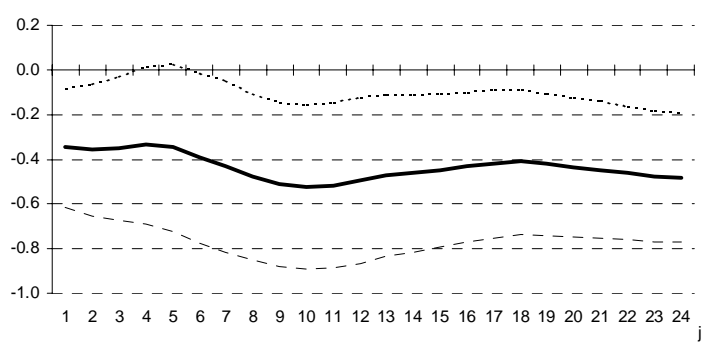

Coefficient estimates for Canada-Italy

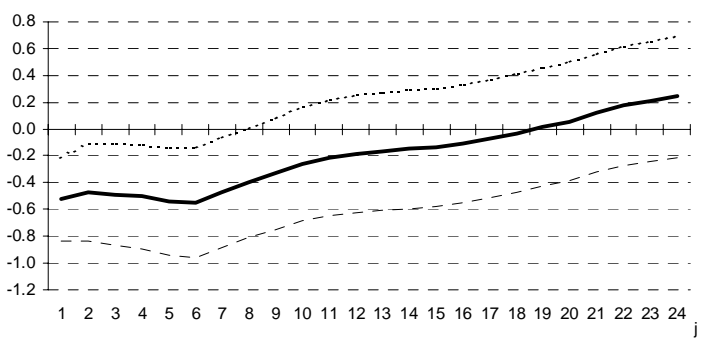




\section{Figure 2}

\section{(continued)}

Coefficient estimates for France-Italy

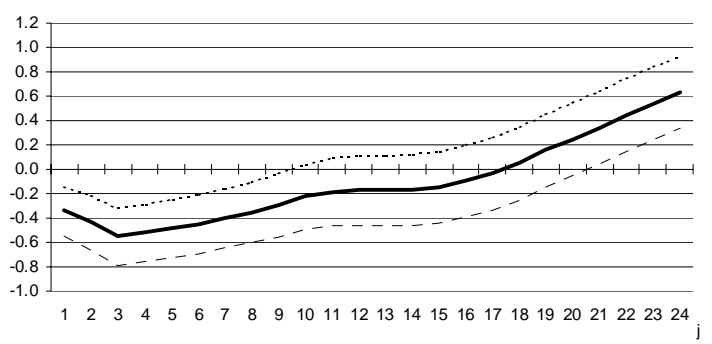

Coefficient estimates for Norway-Italy

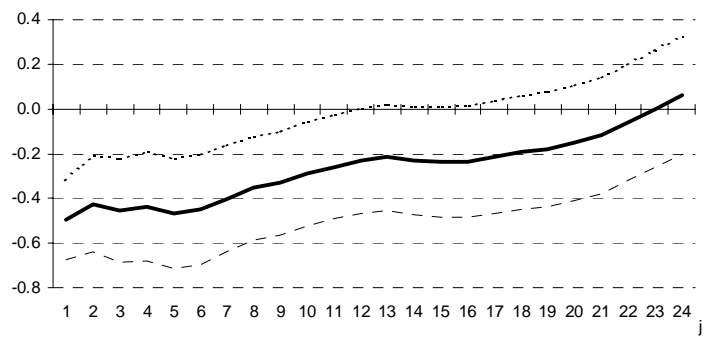

Coefficient estimates for Switzerland-Italy

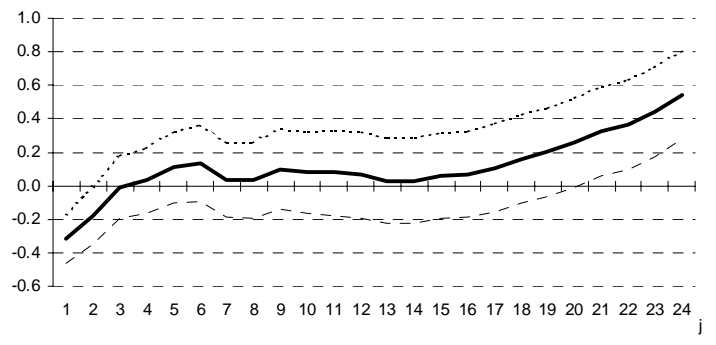

Coefficient estimates for Denmark-Italy

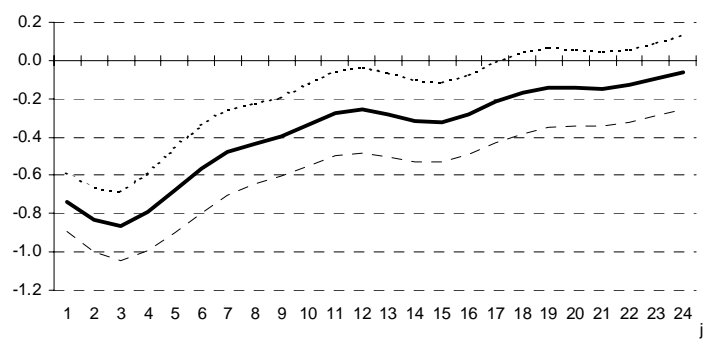

Coefficient estimates for Netherlands-France

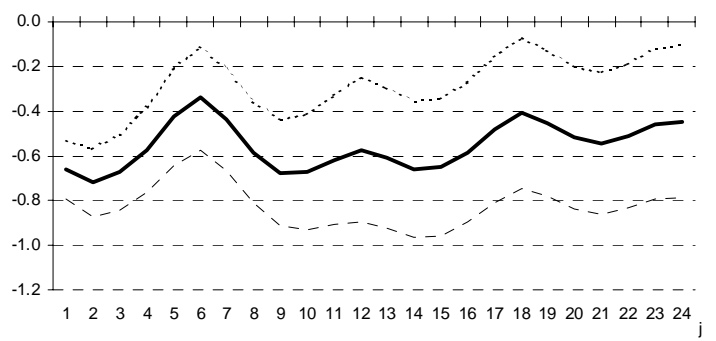

Coefficient estimates for Netherlands-Italy

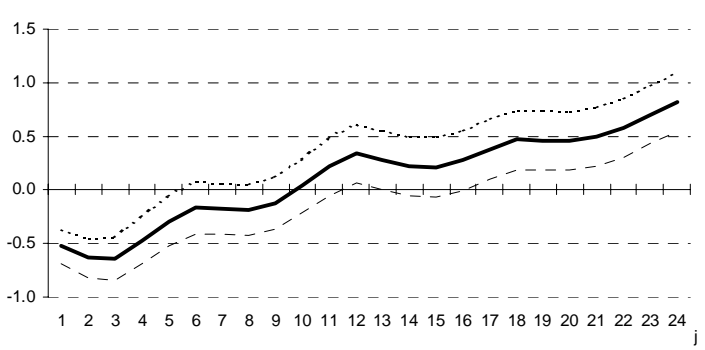

Coefficient estimates for Belgium-Italy

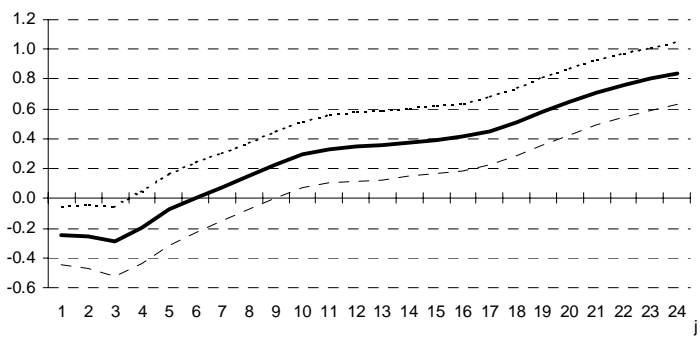

Coefficient estimates for Spain-Italy

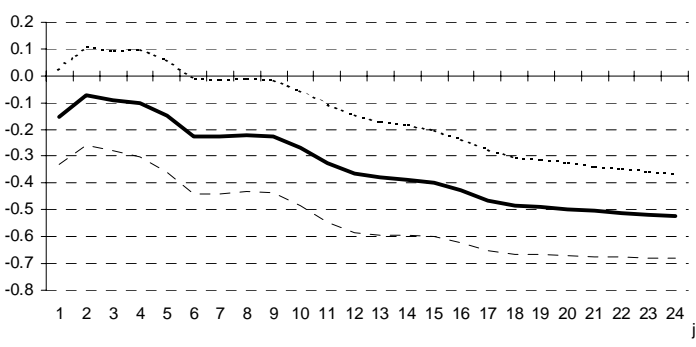

Coefficient estimates for Canada-France

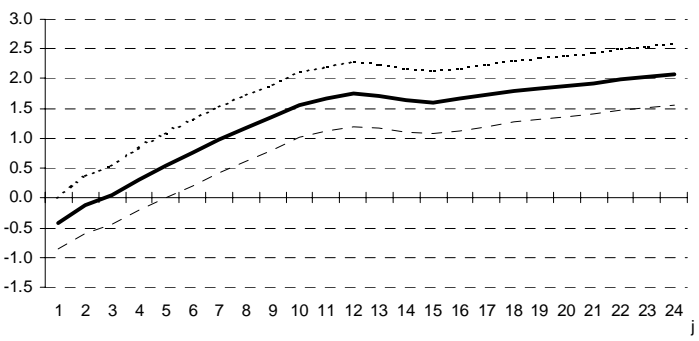

Coefficient estimates for Norway-France

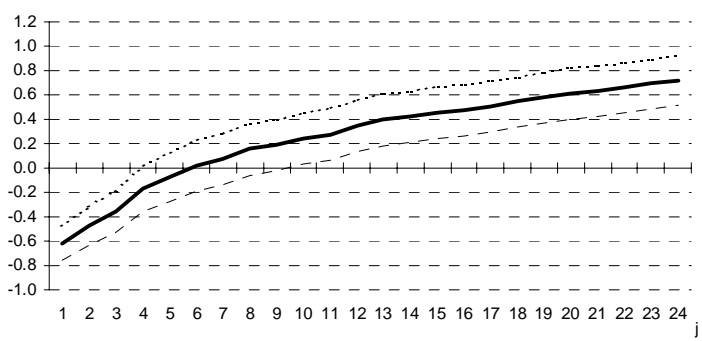




\section{Figure 2}

\section{(continued)}

Coefficient estimates for Belgium-France

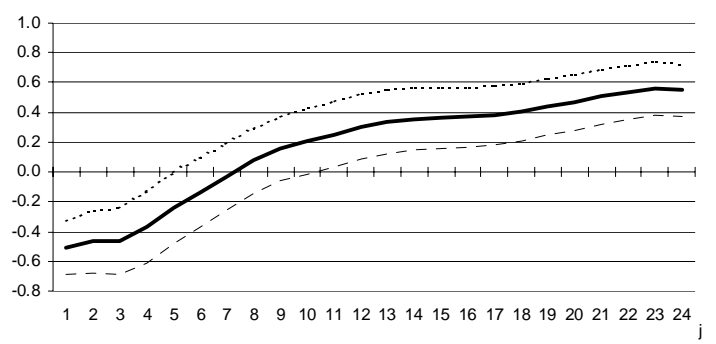

Coefficient estimates for Spain-France

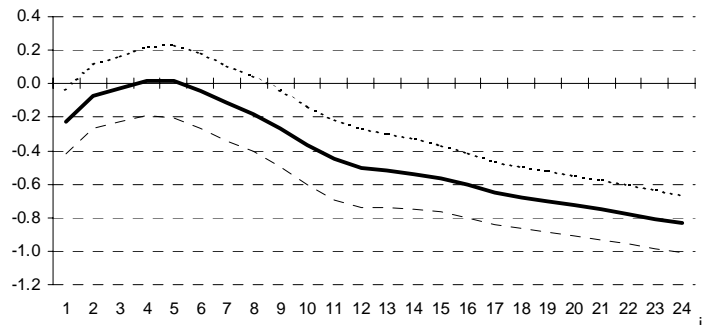

Coefficient estimates for Netherlands-Canada

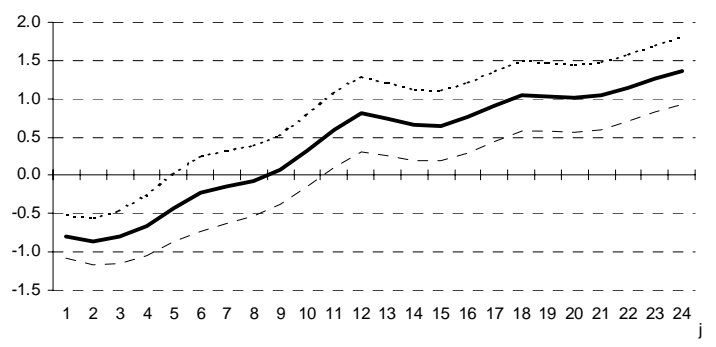

Coefficient estimates for Belgium-Canada

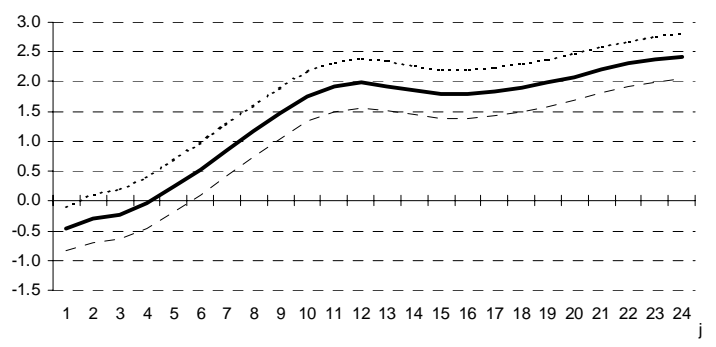

Coefficient estimates for Spain-Canada

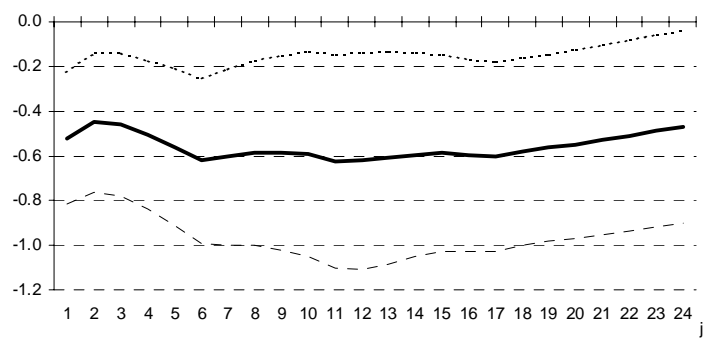

Coefficient estimates for Switzerland-France

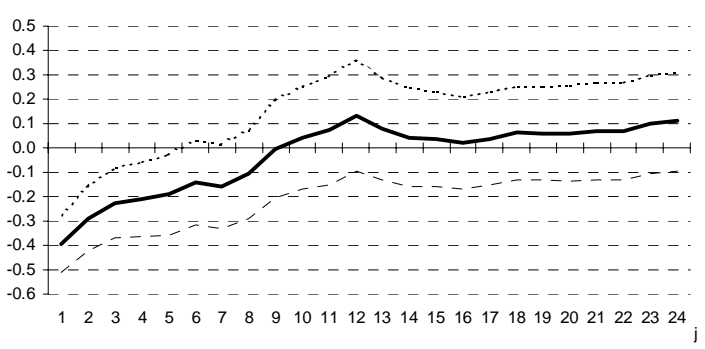

Coefficient estimates for Denmark-France

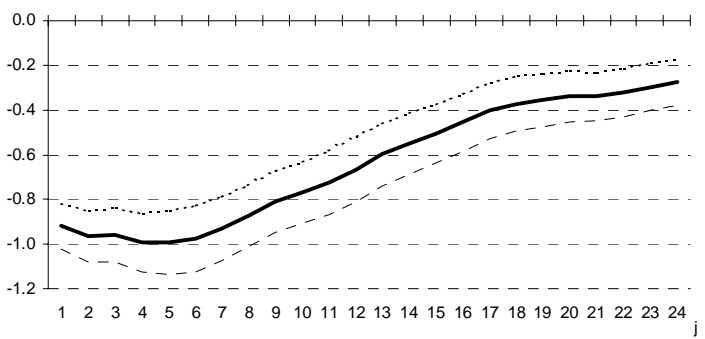

Coefficient estimates for Norway-Canada

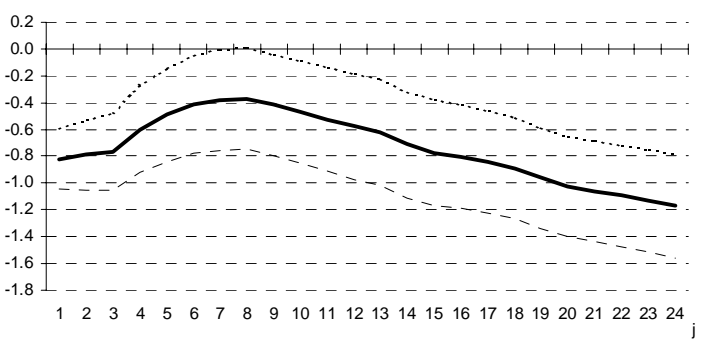

Coefficient estimates for Switzerland-Canada

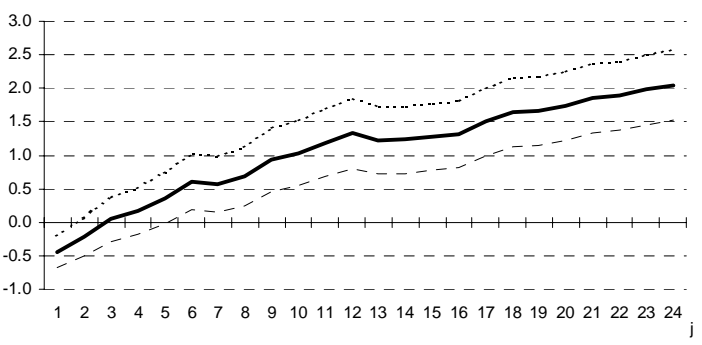

Coefficient estimates for Denmark-Canada

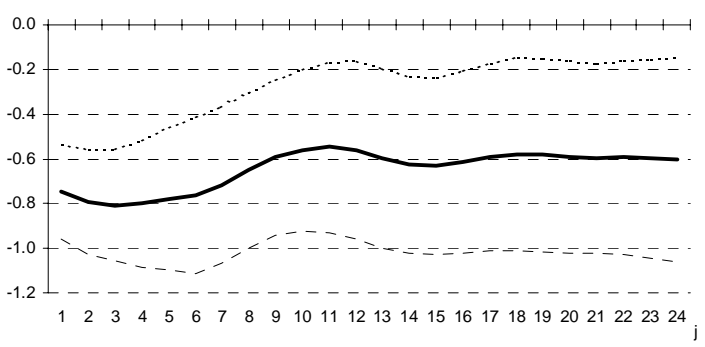




\section{Figure 2}

\section{(continued)}

Coefficient estimates for Norway-Netherlands

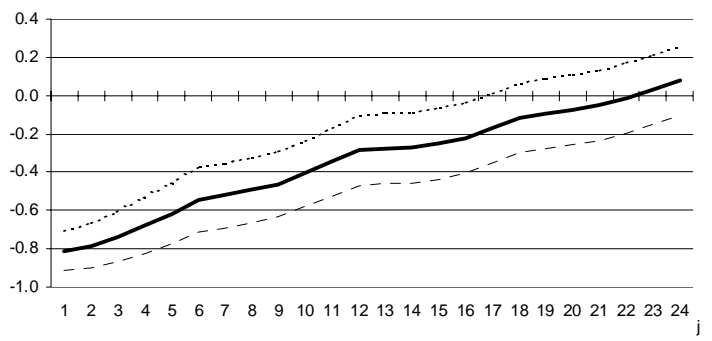

Coefficient estimates for Switzerland-Netherlands

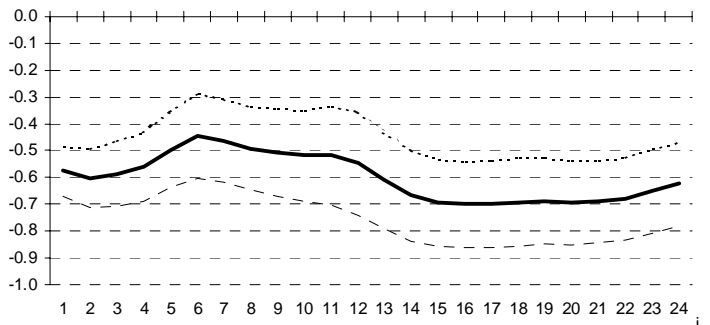

Coefficient estimates for Denmark-Netherlands

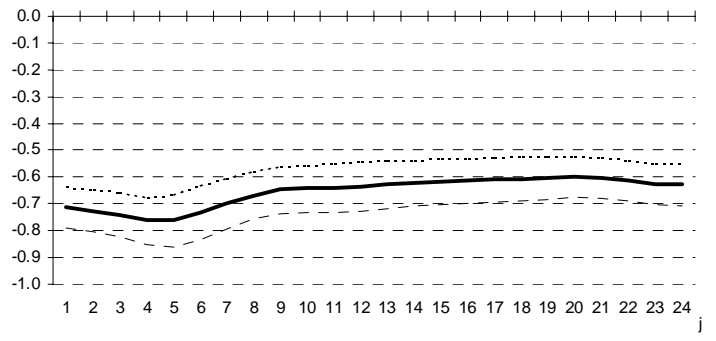

Coefficient estimates for Switzerland-Norway

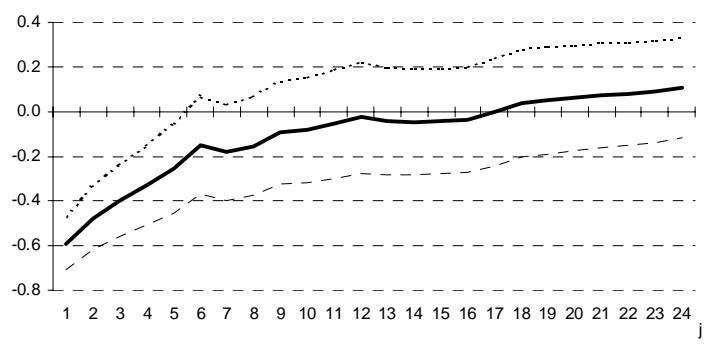

Coefficient estimates for Denmark-Norway

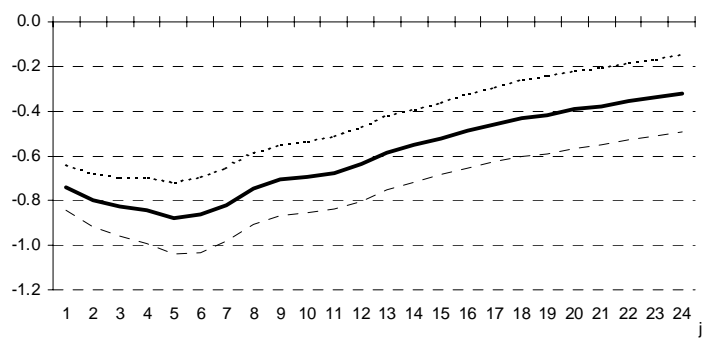

Coefficient estimates for Belgium-Netherlands

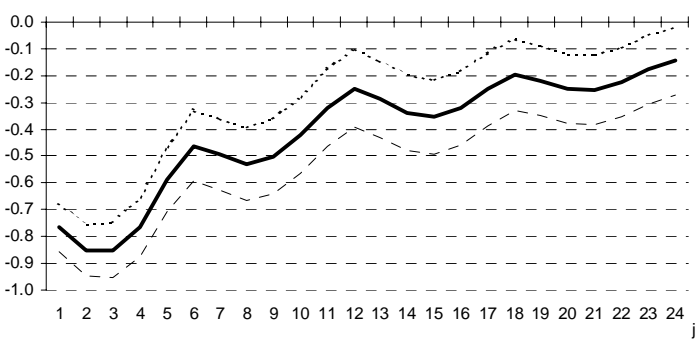

Coefficient estimates for Spain-Netherlands

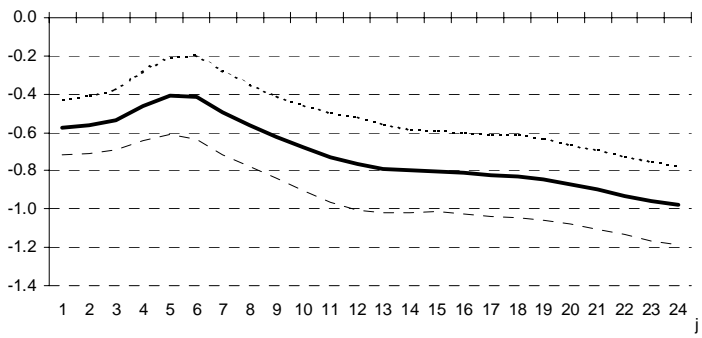

Coefficient estimates for Belgium-Norway

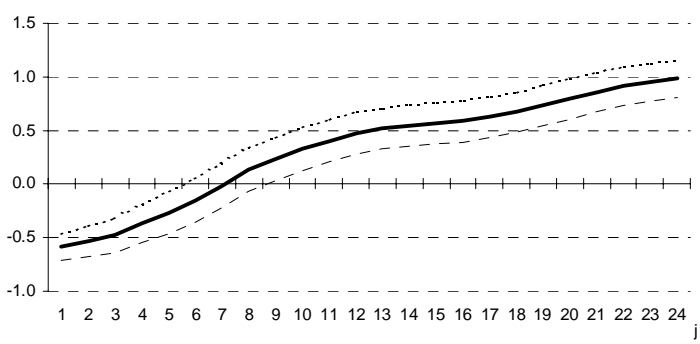

Coefficient estimates for Spain-Norway

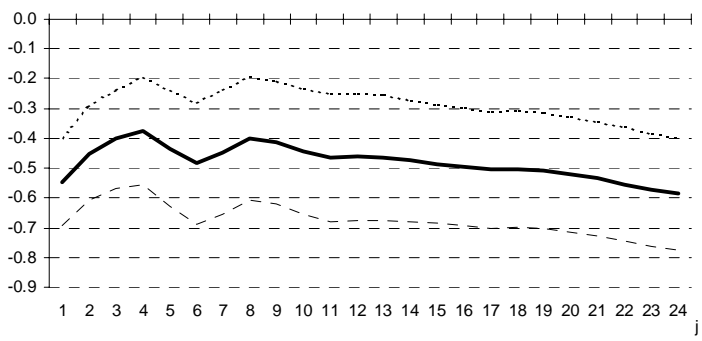

Coefficient estimates for Switzerland-Belgium

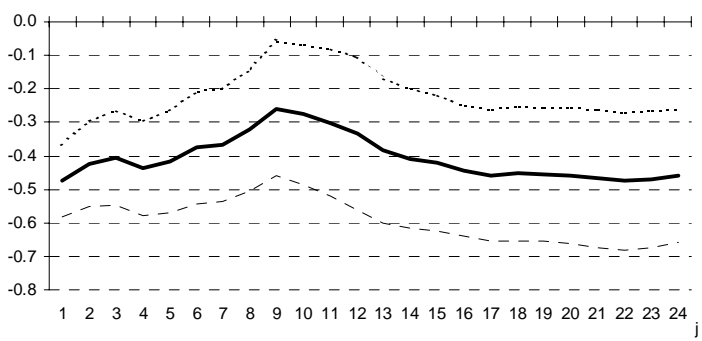




\section{Figure 2}

\section{(continued)}

Coefficient estimates for Spain-Belgium

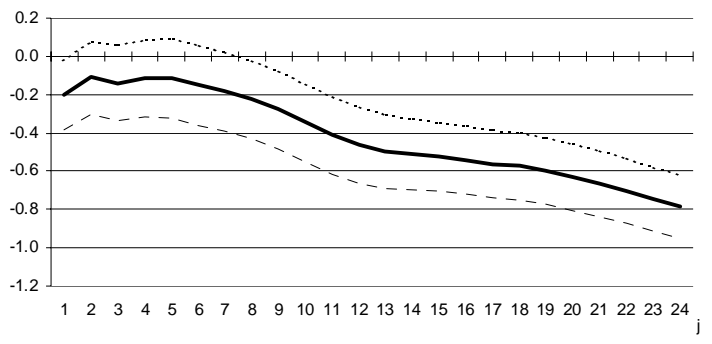

Coefficient estimates for Spain-Switzerland

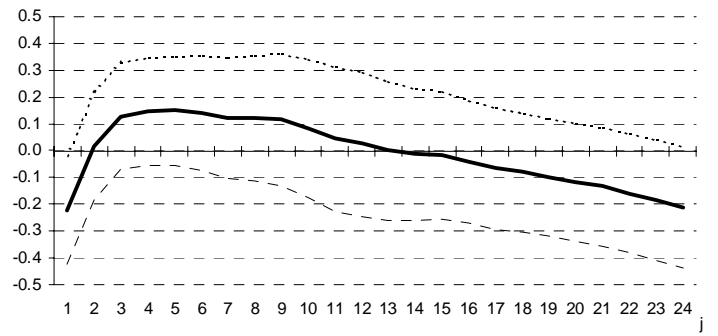

Coefficient estimates for Denmark-Spain

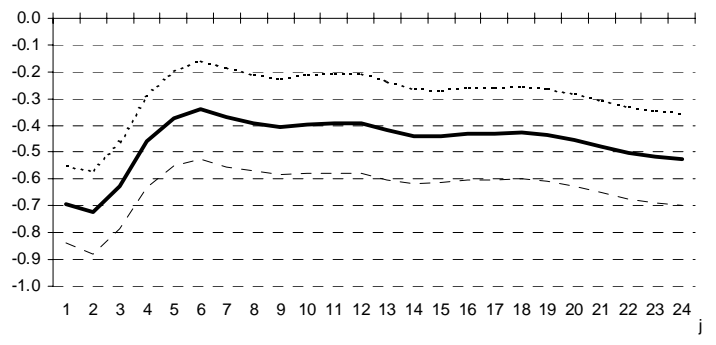

Coefficient estimates for Denmark-Belgium

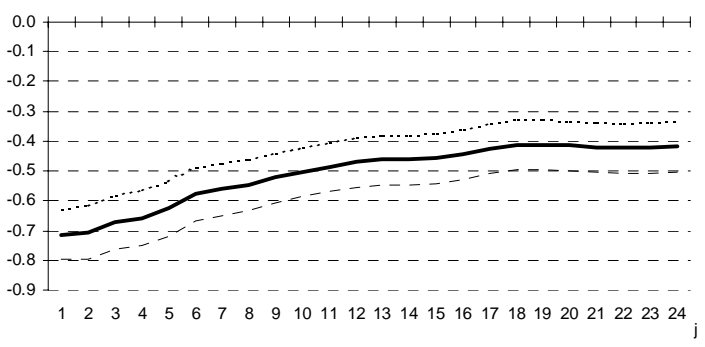

Coefficient estimates for Denmark-Switzerland

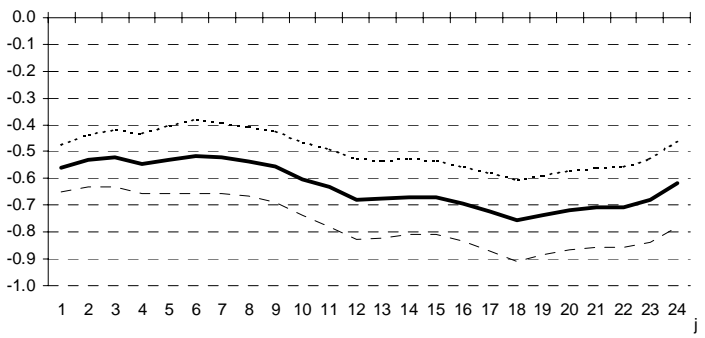

(Horizontal axis: horizon (in months.) Plotted is slope coefficient of regression of relative traded prices on service price, and 95 percent confidence interval.) 


\section{Figure 3}

\section{R-Squareds from Regressions Reported in Figure 2}

R-Square for Canada-US

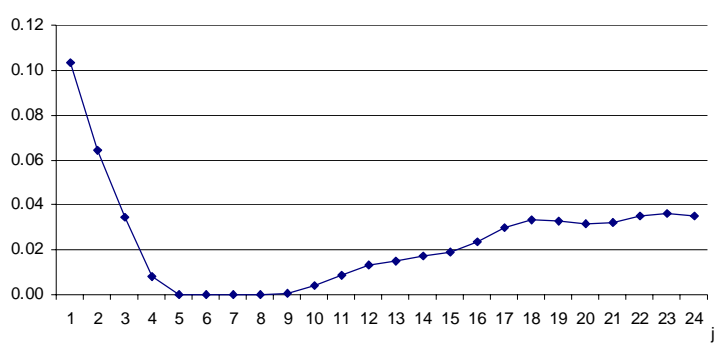

R-Square for Italy-US

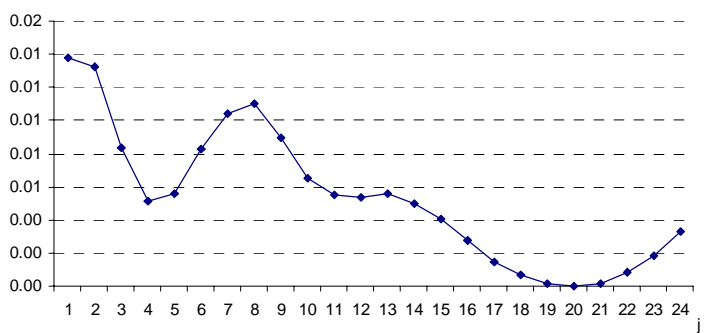

R-Square for Netherlands-US

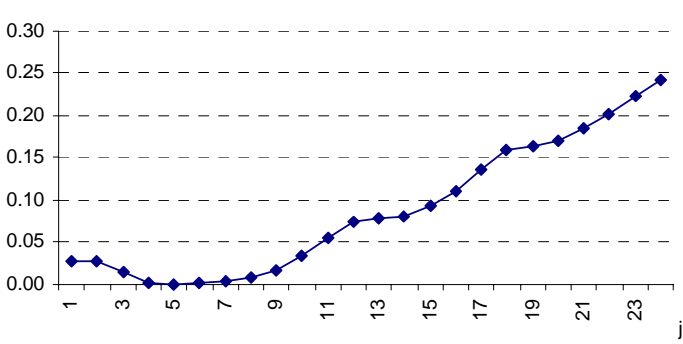

R-Square for Belgium-US

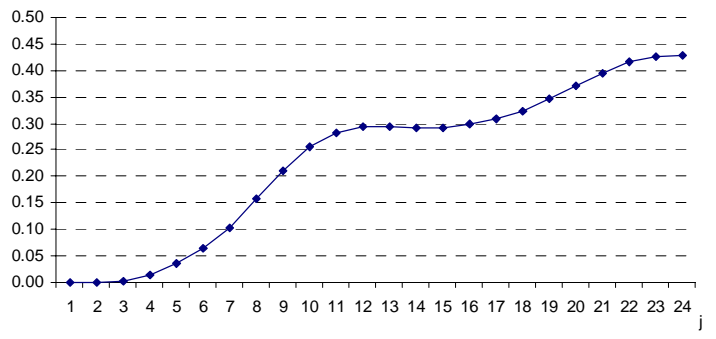

R-Square for Spain-US

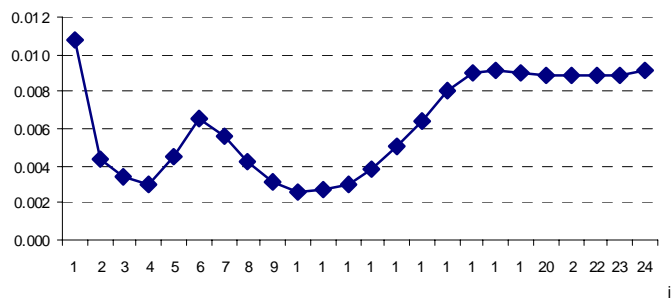

R-Square for France-US

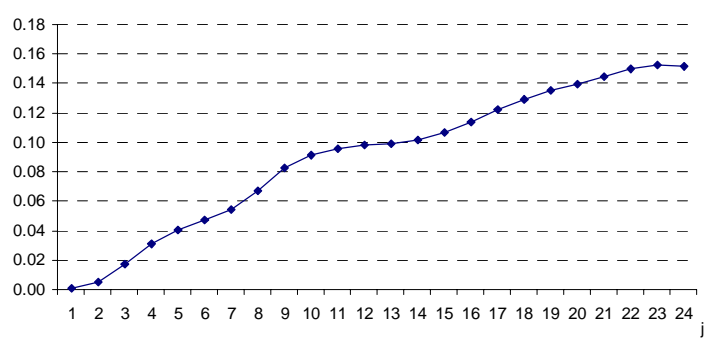

R-Square for Japan-US

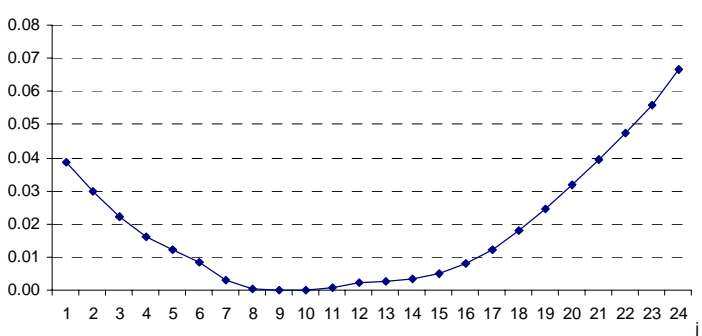

R-Square for Norway-US

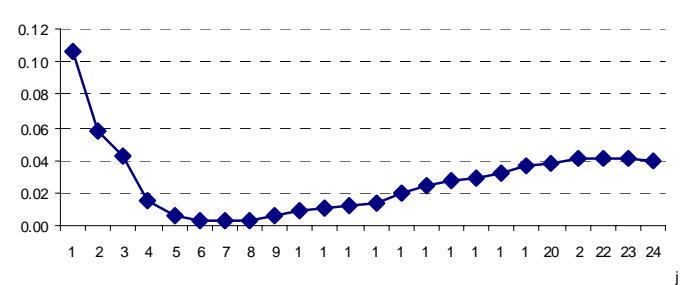

R-Square for Switzerland-US

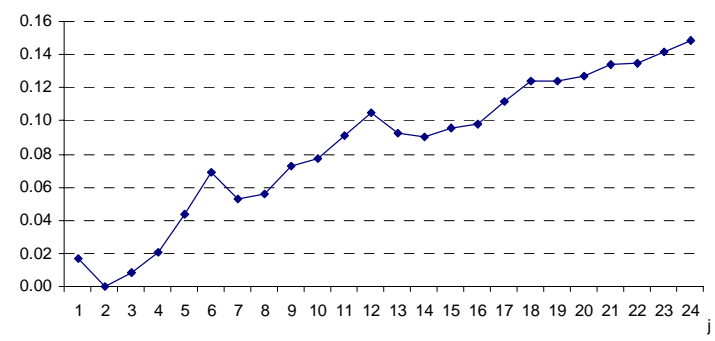

R-Square for Denmark-US

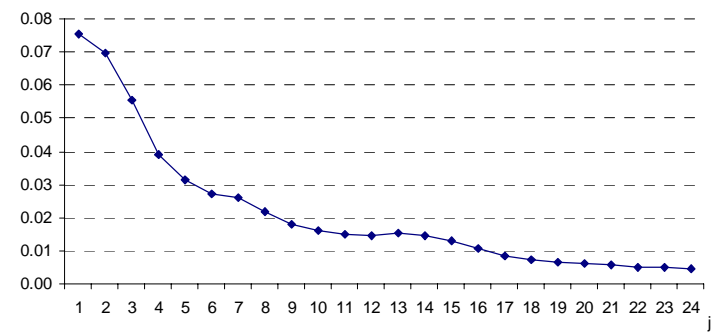




\section{Figure 3}

\section{(continued)}

R-Square for Canada-Japan

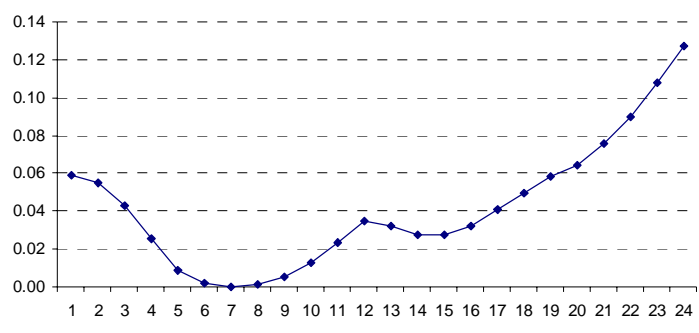

R-Square for Italy-Japan

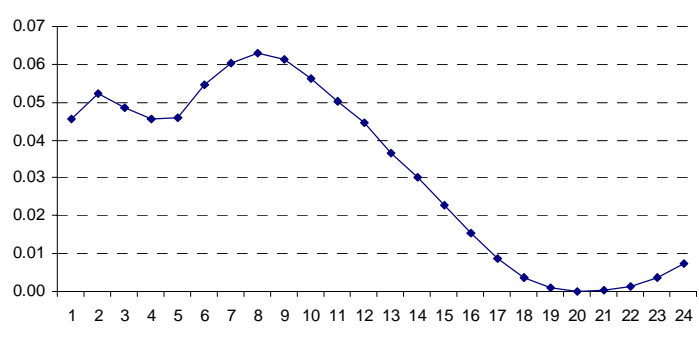

R-Square for Norway-Japan

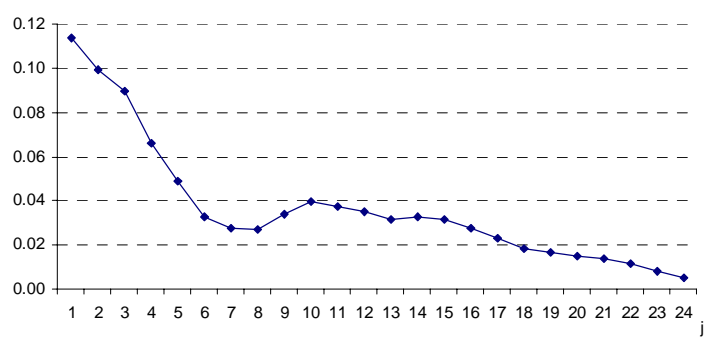

R-Square for Switzerland-Japan

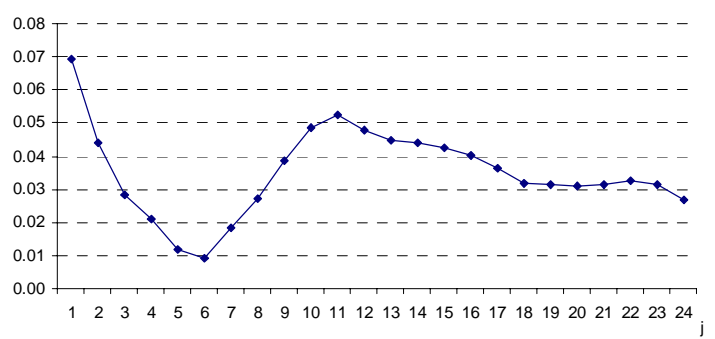

R-Square for Denmark-Japan

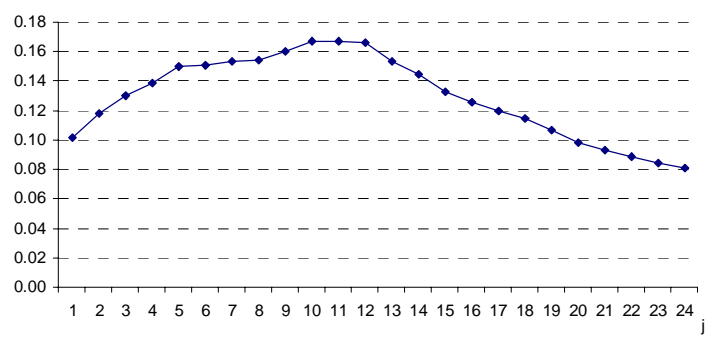

R-Square for France-Japan

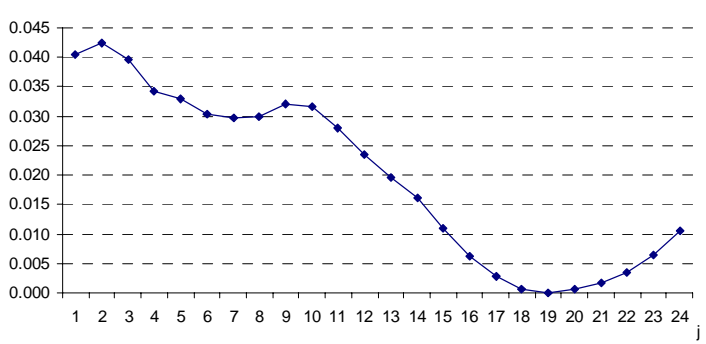

R-Square for Netherlands-Japan

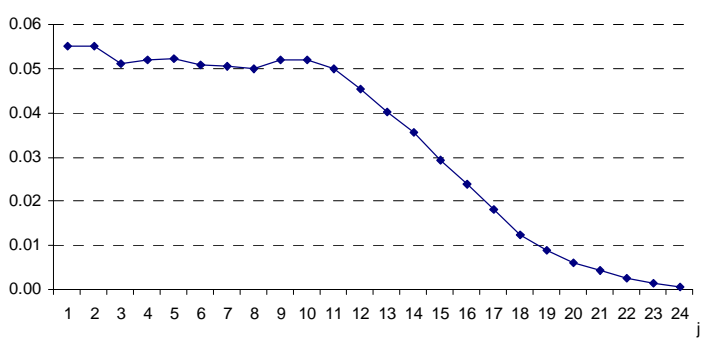

R-Square for Belgium-Japan
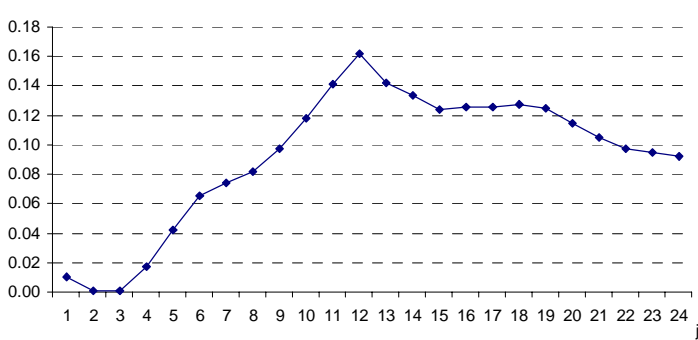

R-Square for Spain-Japan

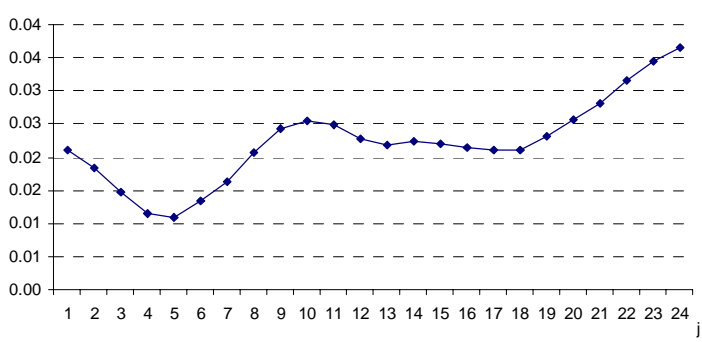

R-Square for Canada-Italy

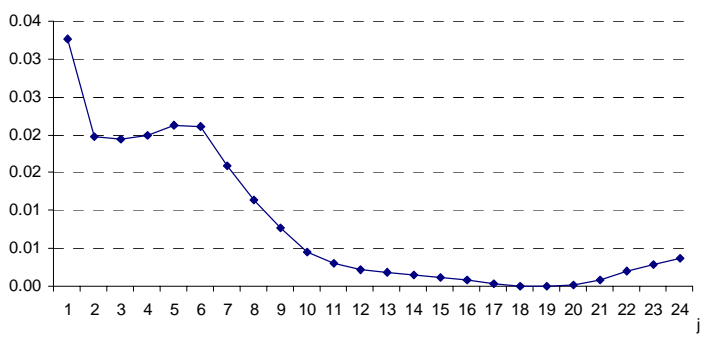




\section{Figure 3}

\section{(continued)}

R-Square for France-Italy

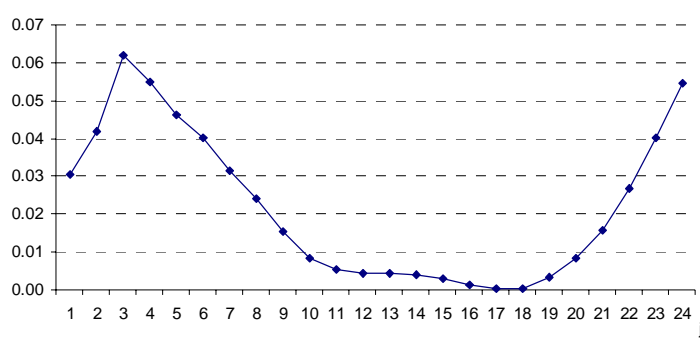

R-Square for Norway-Italy

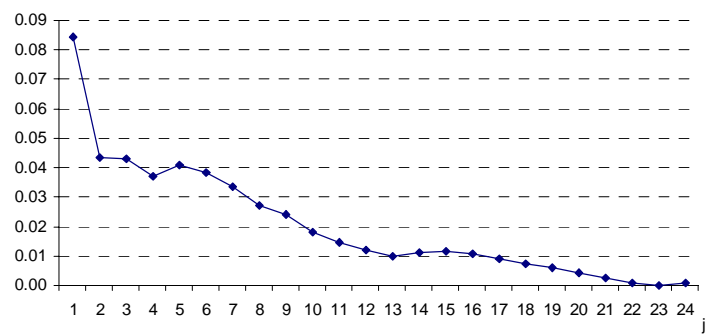

R-Square for Switzerland-Italy

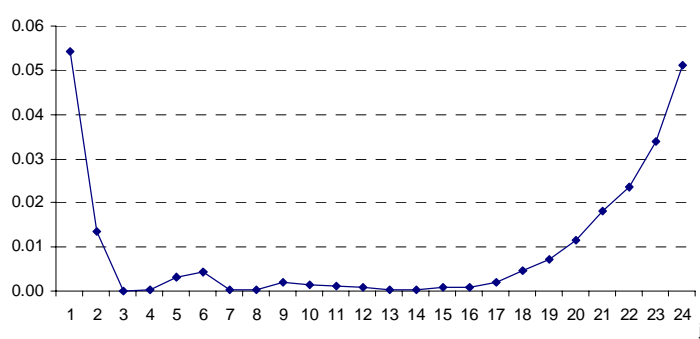

R-Square for Denmark-Italy

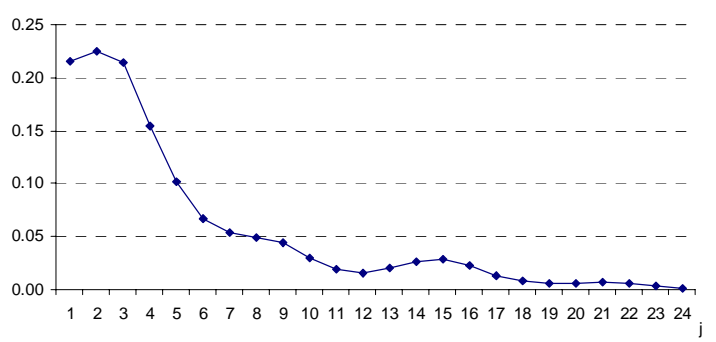

R-Square for Netherlands-France

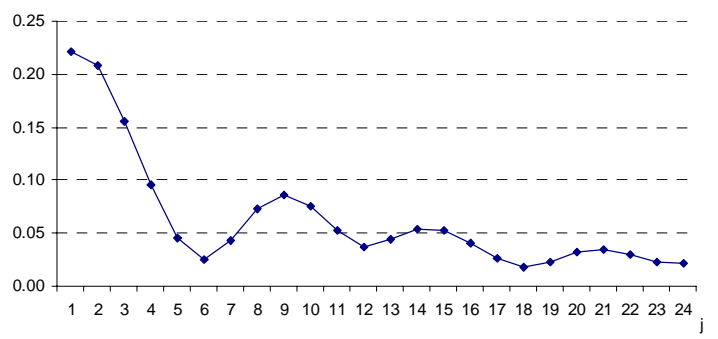

R-Square for Netherlands-Italy

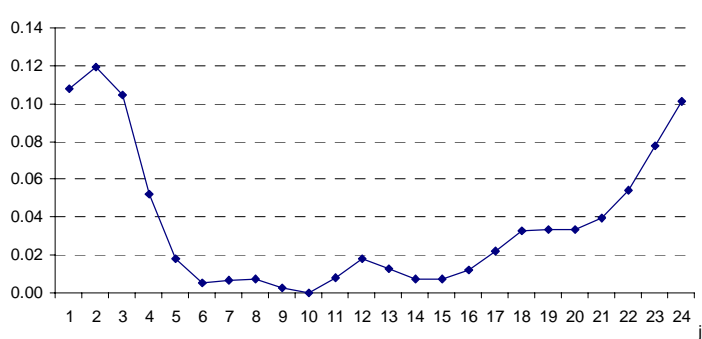

R-Square for Belgium-ltaly

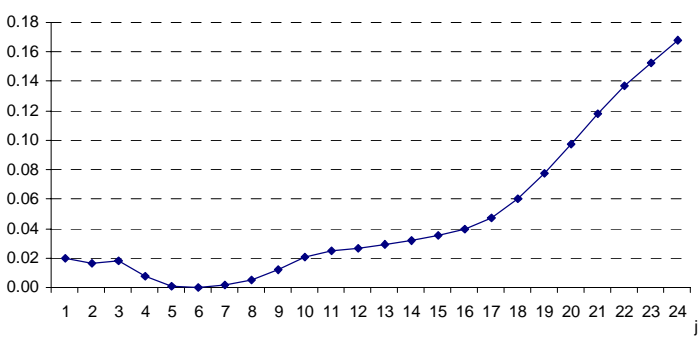

R-Square for Spain-Italy

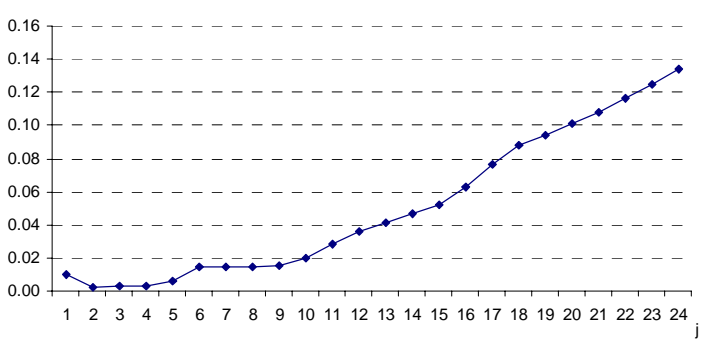

R-Square for Canada-France

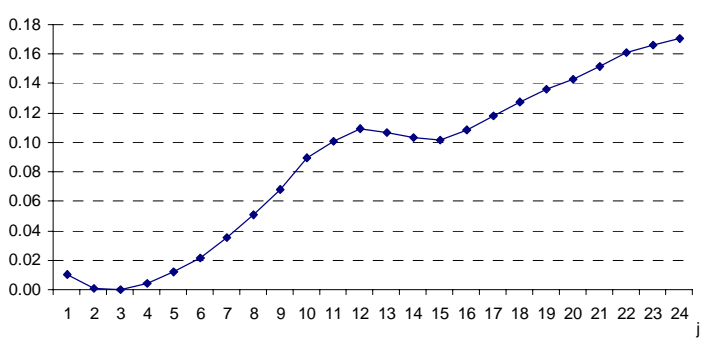

R-Square for Norway-France

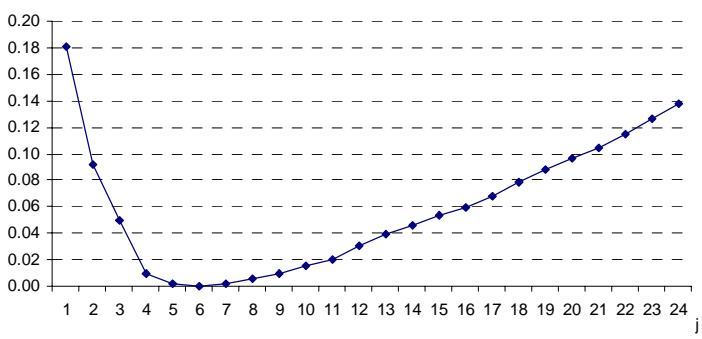




\section{Figure 3}

\section{(continued)}

R-Square for Belgium-France

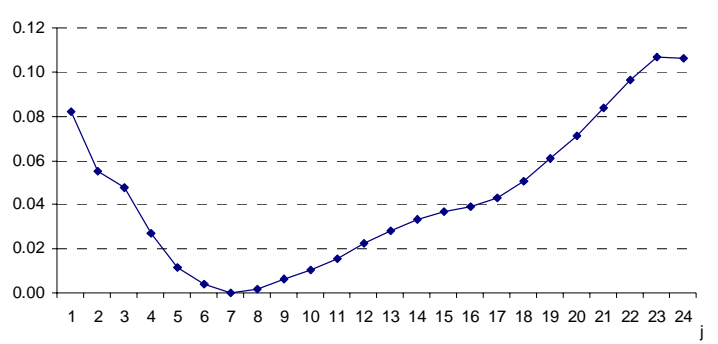

R-Square for Spain-France

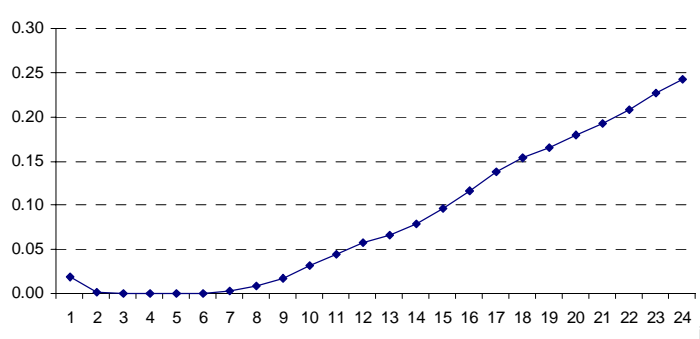

R-Square for Netherlands-Canada

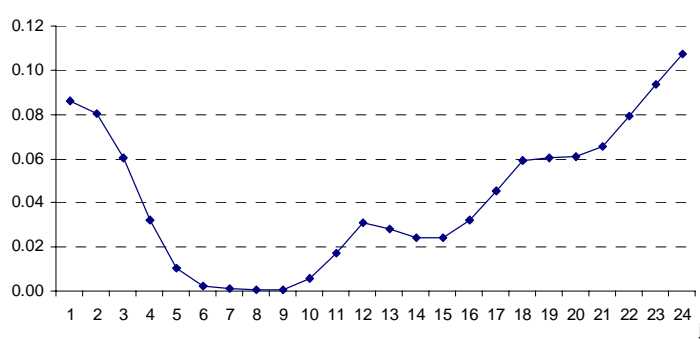

R-Square for Belgium-Canada

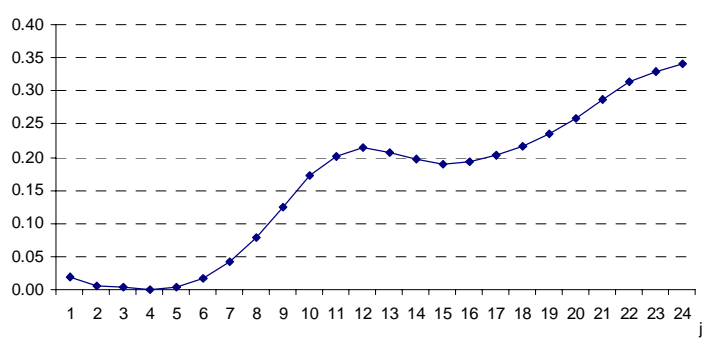

R-Square for Spain-Canada

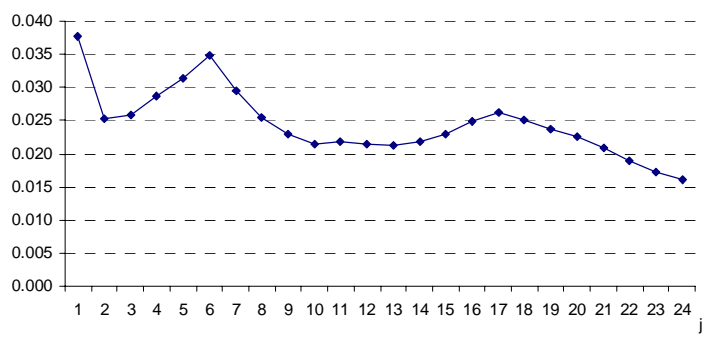

R-Square for Switzerland-France

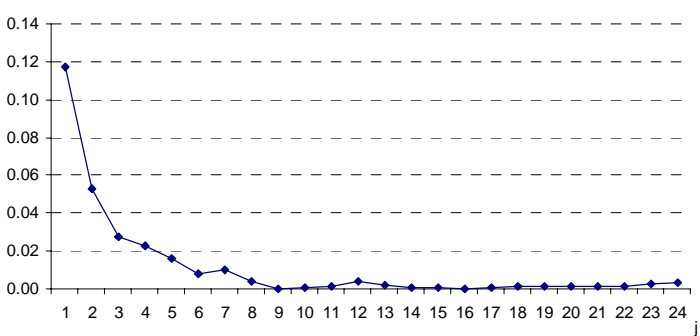

R-Square for Denmark-France

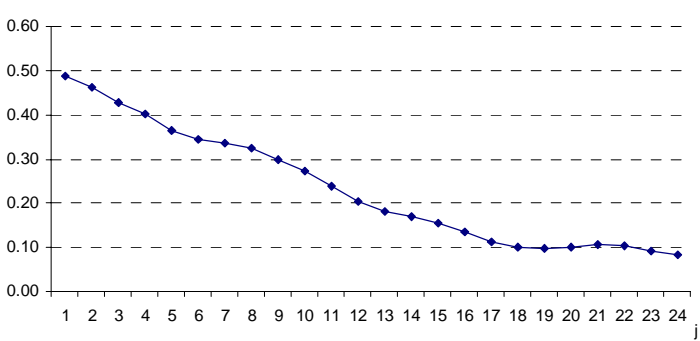

R-Square for Norway-Canada

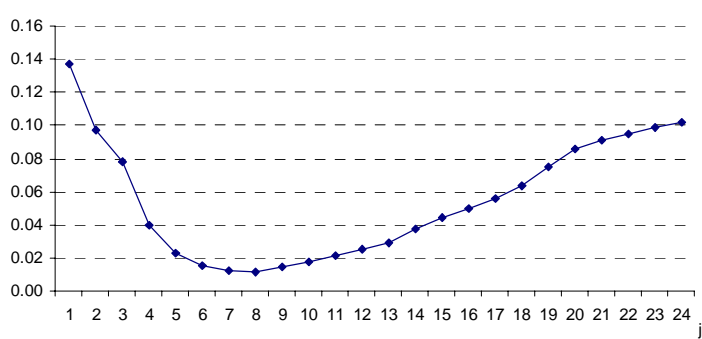

R-Square for Switzerland-Canada

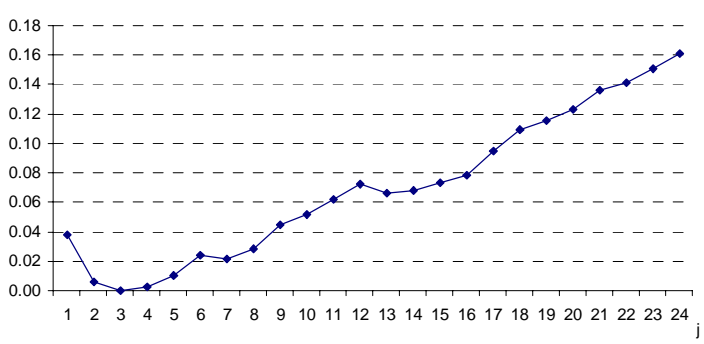

R-Square for Denmark-Canada

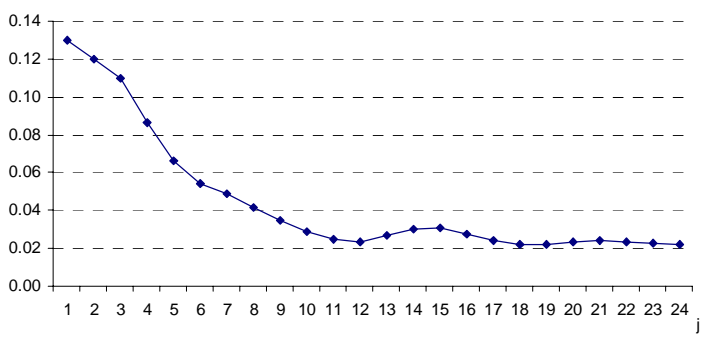




\section{Figure 3}

\section{(continued)}

R-Square for Norway-Netherlands

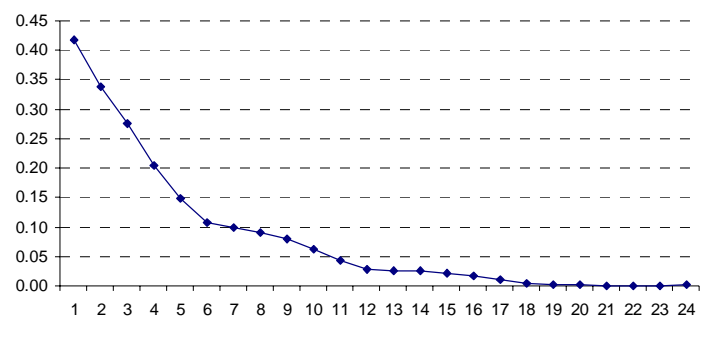

R-Square for Switzerland-Netherlands

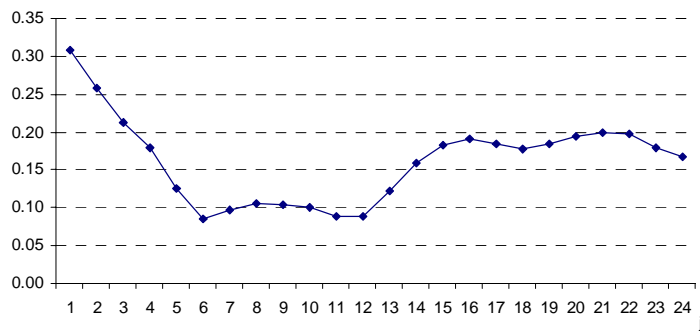

R-Square for Denmark-Netherlands

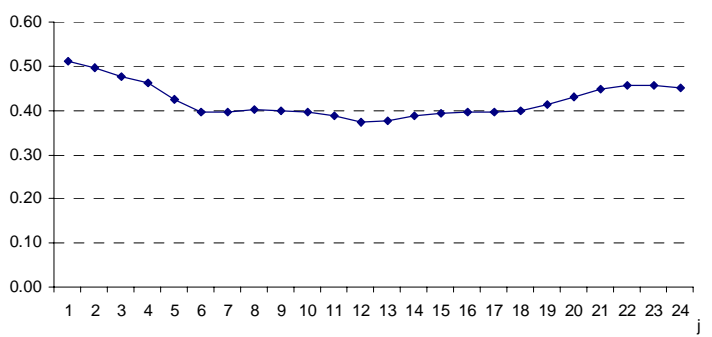

R-Square for Switzerland-Norway

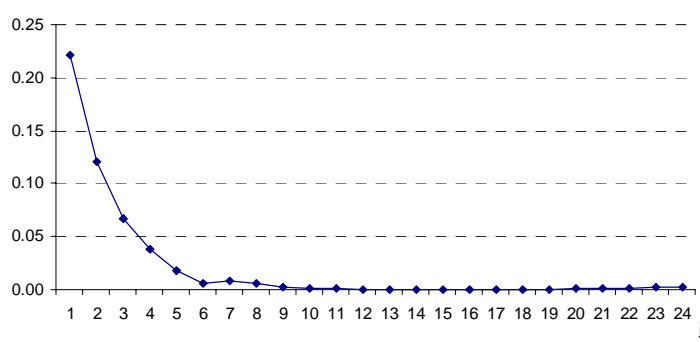

R-Square for Denmark-Norway

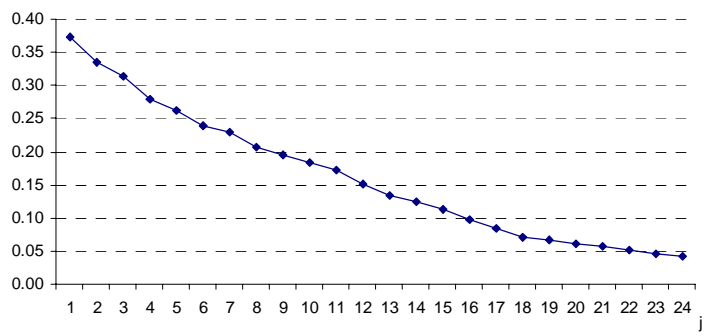

R-Square for Belgium-Netherlands

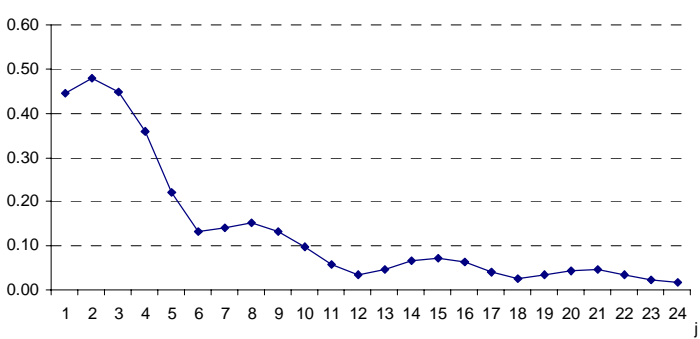

R-Square for Spain-Netherlands

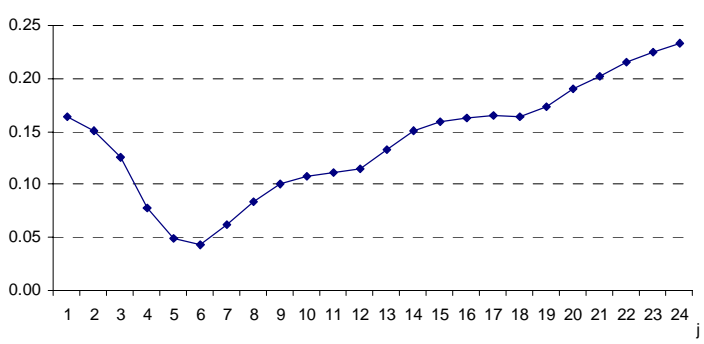

R-Square for Belgium-Norway

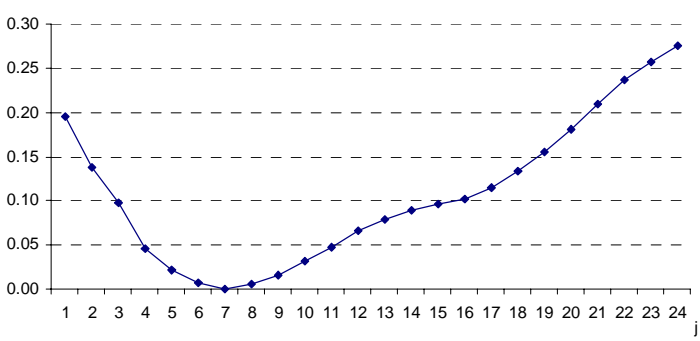

R-Square for Spain-Norway

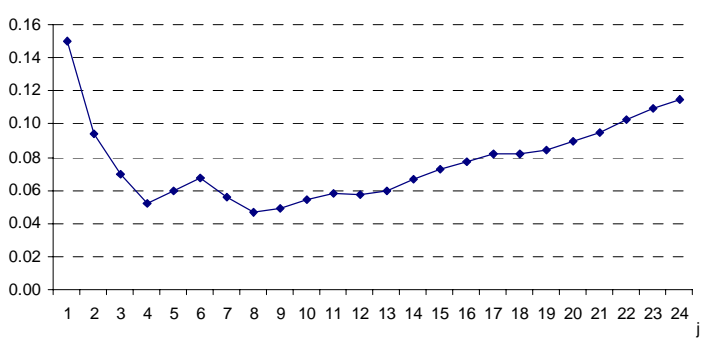

R-Square for Switzerland-Belgium

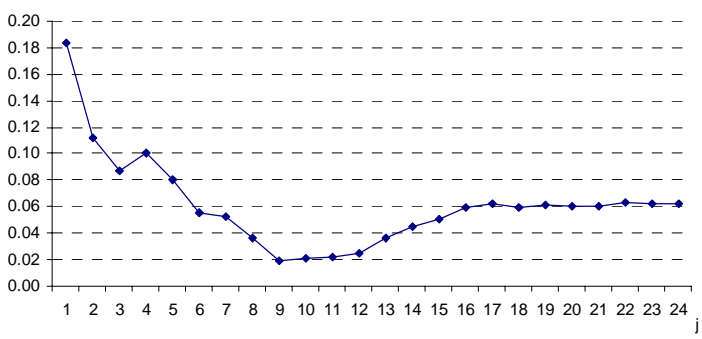




\section{Figure 3}

\section{(continued)}

R-Square for Spain-Belgium

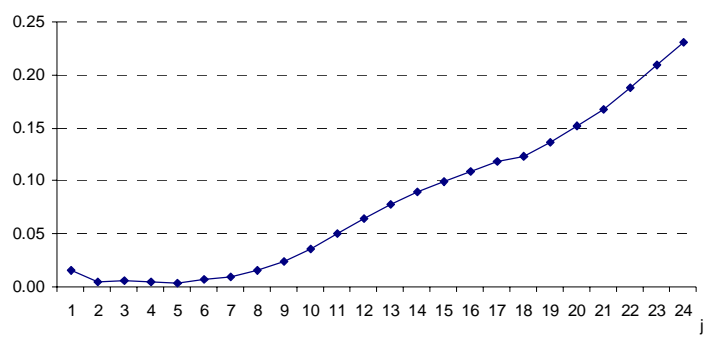

R-Square for Spain-Switzerland

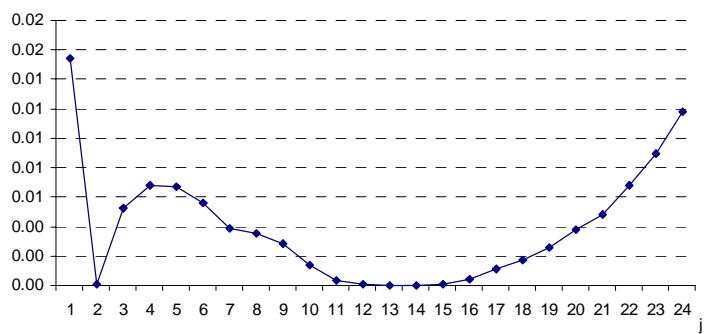

R-Square for Denmark-Spain

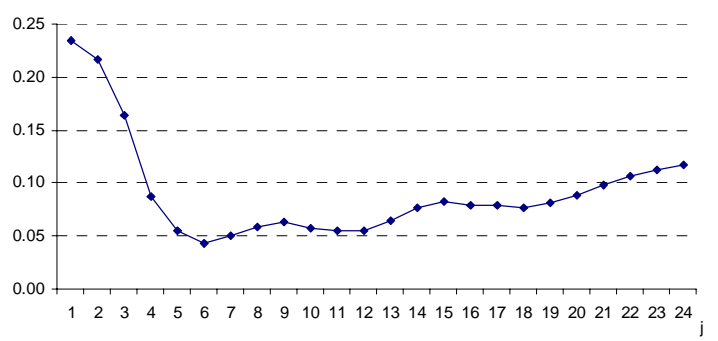

R-Square for Denmark-Belgium

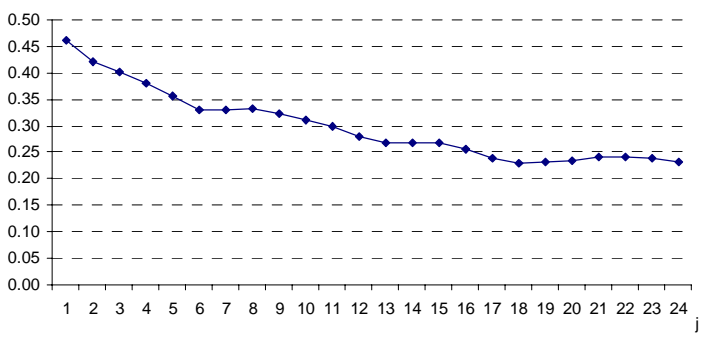

R-Square for Denmark-Switzerland

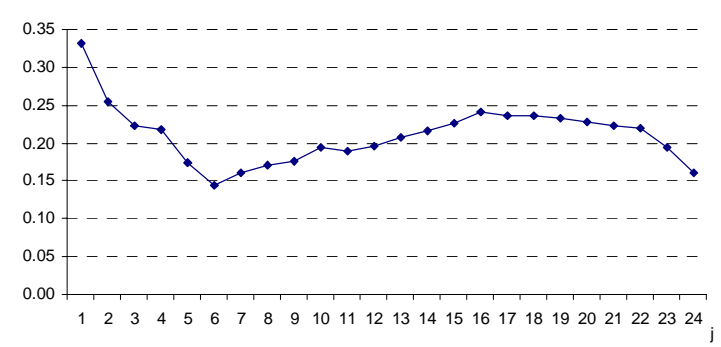

